\title{
A catalogue of major and trace element data for Icelandic Holocene silicic tephra layers
}

\author{
Rh. H. Meara', Th. Thordarson², N. J. G. Pearce ${ }^{3}$, C. Hayward ${ }^{4}$, G. Larsen ${ }^{2}$ \\ ${ }^{1}$ Geography Department, Wallace Building, Swansea University, SA1 8PP, UK \\ ${ }^{2}$ Institute of Earth Sciences, Building of Natural Sciences, IS-101 Reykjavík, Iceland \\ ${ }^{3}$ Department of Geography and Earth Sciences, Aberystwyth University, SY23 3DB, UK \\ ${ }^{4}$ School of GeoSciences, Grant Institute, Kings Buildings, University of Edinburgh, EH9 3FE, \\ UK
}

\section{Abstract}

Tephra layers with Icelandic provenance have been identified across the North Atlantic region in terrestrial, lacustrine, marine and glacial environments. These tephra layers are used as marker horizons in tephrochronology including climate studies, archaeology, and environmental change. The major element chemistry of 19 proximally-deposited Holocene Icelandic silicic tephra layers confirm that individual volcanic systems have unique geochemical signatures and that eruptions from the same system can often be distinguished. In addition, glass trace element chemistry highlights subtle geochemical variations between tephra layers which appear to have identical major element chemistry and thus allows for the identification of some, if not all, tephra layers previously considered to be identical in composition. This paper catalogues the compositional variation between the widespread Holocene Icelandic silicic tephra deposits.

\section{Introduction}

Volcanic eruptions are geologically "instantaneous" events and tephra, including ash, from explosive eruptions can be widely dispersed. Such eruptions have resulted in the distribution of a large number of Icelandic tephras across the North Atlantic region (e.g. Hall et al. 2002; 
van den Bogaard et al. 2002a,b; Chambers et al. 2004; Davies et al. 2005, 2010; Abbott et al. 2018). Tephrochronological studies have identified, characterised and correlated Icelandic tephras, both visible tephra layers and cryptotephra deposits, which have been used to date and correlate events in the region such as climatic perturbations (e.g. Caseldine et al. 1998; Dugmore et al. 2000; Langdon and Barber, 2004; Streeter et al. 2012), anthropological and archaeological episodes (e.g. Buckland et al. 1997) and variations in flora and fauna species concentrations (e.g. Blackford et al. 1992; Hall et al. 1994b).

The interaction of the spreading Mid-Atlantic ridge and the proposed Icelandic mantle plume has resulted in a large number of active volcanic systems in Iceland. Magma generation processes differ between the Icelandic volcanic systems. Theories for the formation of silicic magmas typically focus on i) partial melting of crustal material and ii) fractional crystallisation of magma, with the volcano's location relative to active rifting impacting on final compositions (e.g. Sigmarsson, 1991; Martin and Sigmarsson, 2007, 2010; Sverrisdottir, 2007; Bindeman et al. 2012; Banik et al. 2018). These differing processes result in individual systems showing specific geochemical signatures that can be used to assign provenance to their eruptive products.

The identification of tephra horizons is typically achieved by analysing the compositions of individual juvenile glass shards by electron probe microanalysis (EPMA) for major elements and laser ablation (LA) ICP-MS for trace elements (see Pearce et al. 2004b, 2014; Lowe et al. 2017). Major element composition of glass has proved effective for confirming the provenance of tephra layers and to some extent for identifying individual tephra layers sourced from within the same system. However, the major element composition of tephra layers derived from the same volcanic system can be identical, hence limiting the reliability of their identification in the absence of additional information (e.g. stratigraphic context, or ${ }^{14} \mathrm{C}$ dating). Trace elements, however, are sensitive to minor variations in both melting conditions and fractional crystallisation. Their concentrations vary depending on melt source (i.e. what material is melting to produce magma), contamination by surrounding country rock, volatile content etc). Glass shard trace element chemistry therefore can be used to facilitate discrimination between tephra layers that have identical major element compositions. 
Since the late 1960s, tephrochronological studies have relied heavily on the application of EPMA to determine the major element chemistry of juvenile glass shards for the identification of tephra layers (e.g. Smith and Westgate, 1968; Larsen, 1981; Dugmore et al. 1995a,b; Davies et al. 2005). EPMA is relatively cheap, widely available and essentially non-destructive.

Analyses of trace elements in tephra deposits prior to the mid 1990s had a limited application (e.g. Westgate and Gorton, 1982; Basile et al. 2001, Begét and Keskinen, 2003). Some trace element studies of tephra from the North Atlantic were undertaken (e.g. Lacasse et al. 1995; Wallrabe-Adams and Lackschewitz, 2003), but the techniques used were generally expensive, required careful sample separation, were less readily available than EPMA, and often irreversibly damaged the samples analysed (e.g. by dissolving the samples for analysis). However, the development of the LA-ICP-MS technique in the early 1990s, with improvements from the early 2000s to improve spatial resolution greatly increased the potential to apply glass-shard-derived trace element data to tephrochronological studies (e.g. Bryant et al. 1999; Pearce et al. 1996, 1999, 2004a). Since the early 2010s, LA-ICP-MS analyses of glass shards have become a significant component of many tephra studies (e.g. Abbott et al. 2016; Cook et al. 2018; Lane et al. 2015). These developments are of great importance as trace elements show a much higher sensitivity to minor changes in melt generation and evolution processes than do the major elements (Pearce et al. 2008). These differences can be used to highlight small-scale variations between volcanic systems and their derived tephra layers, and potentially result in a more reliable method for identifying distal tephra deposits.

Of the 30 active volcanic centres in Iceland, seven have erupted broadly silicic magmas during the Holocene period: Torfajökull, Askja, Katla, Öræfajökull, Hekla, Eyjafjallajökull and Snæfellsjökull (Fig. 1). These volcanic systems have erupted over 70 times since 10,300 b2k (years before $2000 \mathrm{AD}$ ), generating a combined volume of tephra exceeding around $13 \mathrm{~km}^{3}$ when calculated as dense rock equivalent of magma (DRE; Thordarson and Höskuldsson, 2008). For the purpose of this paper, the term "silicic" is used to refer to magma with a $\mathrm{SiO}_{2}$ composition of $60 \mathrm{wt} \%$ or more.

In the following sections, we present new EPMA and LA-ICP-MS data collected at proximal locations for 19 Holocene silicic Icelandic eruptions known to have generated tephras that were widely dispersed across the North Atlantic region, as well as tephra deposits not yet 
found beyond Iceland (Table 1). Thirteen tephra layers were sampled from the Hekla volcanic system, including five that were widely dispersed: H1104 (896 b2k), H3 (3060 b2k), HS (3840 b2k), H4 (4250 b2k), H5 (7125 b2k). Eight smaller scale eruptions are currently known only from deposits in Iceland and are termed HA, HB, HC, HM, HN, HX, HY, HZ (2900-1800 b2k). One widely dispersed layer, known as A1875 (125 b2k), was sampled from the Askja volcanic system, and one from the Öræfajökull volcanic system known as Ö1362 (638 b2k). Two tephra layers were sampled from the Katla volcanic system and are known as SILK UN (2830 b2k), SILK LN (3440 b2k); neither were widely dispersed. The Landnám (1123 b2k) and Grákolla (c. 2200 b2k) tephra layers were sampled from the Torfajökull-Vatnaöldur volcanic systems. The Landnám layer is widely dispersed, but the Grákolla layer is so far only identified within Iceland.

This paper is the first compilation of high quality juvenile silicic glass data, both EPMA and LAICP-MS in derivation, to have been collected at proximal Icelandic locations to facilitate tephra identification, reconstruction of volcanic histories and the dispersal of eruptives to distal localities. These data will improve proximal-distal tephra correlation and source identification across the North Atlantic region and, for these eruptives, will alleviate the need for attribution of a volcanic source based on distal tephra data alone.

Using these data, we suggest approaches for identifying individual tephra layers, thereby allowing volcanic provenance to be defined, and suggest ways to distinguish between tephra layers previously considered to be the same using a specific series of elemental comparisons.

The eruption of Eyjafjallajökull in 2010 highlighted that wide-spread transportation of pyroclastic material from relatively minor eruptions can occur given the right meteorological conditions (Davies et al. 2010; Gudmundsson et al. 2012). With this in mind, some less widely dispersed tephra layers have been included in the analyses (i.e. HA-HZ). Although these layers are currently not known outside Iceland, emphasising their existence to the North Atlantic tephra community, who typically work in distal rather than proximal localities, may assist in their studies.

\section{Methodology}


1 Tephra deposits erupted from Torfajökull, Askja, Katla, Öræfajökull, and Hekla were selected

2 for their wide dispersal and known occurence across the North Atlantic region (Table 1, Fig.

3 2; e.g. Dugmore, 1989; Davies et al. 2007; Eiríksson et al. 2000; Larsen et al. 2002). Samples

4 for geochemical analysis were collected at proximal reference localities in Iceland (Fig. 3)

5 which were identified based on previous research (e.g. Thorarinsson, 1949) and in

6 collaboration with colleagues at the University of Iceland who provided expert knowledge.

7 Samples were collected to reflect the full eruption sequence of each tephra deposit. Sampling

EPMA glass analyses

Major element analyses were conducted on the Cameca SX100 electron microprobe at the University of Edinburgh. A standard wavelength dispersive setting was used at an accelerating voltage of $15 \mathrm{kV}$ and a beam current of $2 \mathrm{nA}$ for major elements ( $\mathrm{Si}, \mathrm{Al}, \mathrm{Fe}, \mathrm{Mg}, \mathrm{Ca}, \mathrm{Na}, \mathrm{K}$ ) and $80 \mathrm{nA}$ for minor elements ( $\mathrm{Mn}, \mathrm{Ti})$. Beam diameter was $5 \mu \mathrm{m}$, counting times were $20 \mathrm{~s}$ for all elements with the exception of $\mathrm{Mn}$ and $\mathrm{Ti}$ which were $50 \mathrm{~s}$ and $40 \mathrm{~s}$ respectively. Total analysing time was 5 minutes. The Lipari1 (rhyolite) and BHVO2g (basalt) glass standards were measured at regular intervals for quality control and to monitor instrumental drift. ZAF corrections were applied to the data using XPhi Cameca PeakSight software. EPMA settings implemented analytical conditions which minimise the potential for remobilisation and loss of volatile elements such as $\mathrm{Na}$ (Hayward, 2012).

\section{LA-ICP-MS glass analyses}

Trace element analyses were conducted using a Coherent GeoLas ArF 193 nm Excimer laser ablation (LA) system coupled to a Thermo Finnegan Element 2 sector field ICP-MS at the University of Aberystwyth. Trace element data were collected for individual shards using 20 
$\mu \mathrm{m}$ and $10 \mu \mathrm{m}$ diameter ablation craters at a laser fluence of $10 \mathrm{Jcm}^{-2}$ and a repetition rate of $5 \mathrm{~Hz}$ over a 24 second acquisition. Crater size was dependant on the amount of material available for analyses. The minor ${ }^{29} \mathrm{Si}$ isotope was used as the internal standard, with concentrations for individual shards determined by EPMA normalised to an anhydrous basis. Calibration was achieved using NIST SRM 612 with concentrations given in Pearce et al. (1997). A fractionation factor, derived from analyses of reference glasses, was applied to the data to compensate for the differential liberation of elements between the sample and calibration standards resulting from laser-sample interaction (Pearce et al. 2011, 2014). Further details of the analytical procedures, discussion of precision and accuracy, and the procedure for removing any single shard analyses which ablated mineral inclusions are given in Pearce et al. (2007, 2014a, 2014b).

\section{Glass shard compositional data}

Average major and trace element data collected for glass shards extracted from the tephra layers are recorded in Tables 2 and 3. Major element data are recalculated to a (normalised) $100 \%$ anhydrous basis. Samples were collected throughout the stratigraphic bedding of each tephra layer, and the resulting major element compositions of individual glass shards within those samples and are presented as averages +- 1 standard deviation (sd). The data are organised to reflect the multiple samples collected through each tephra layer (sampling heights are noted on the logs within the supplementary information; see supplementary files S1.4, S2.5, S3.2, S4.4, S5.3, S6.3, S6.6, S6.9, S7.3, S9.3, S10.3, S11.3). Several tephra layers contain glass shards that are compositionally bi-modal with silicic and mafic components (Fig. 4). Others may show either continuous grading of compositions, or show evidence of magma mingling (Fig. 5). Where bimodal chemistries have been identified during glass shard analysis, silicic and mafic components are presented separately because the glass shard composition average values are misleading. Compositional grading within the tephra sample is also recorded by the inclusion of analyses of glass from multiple sub-samples for each sample. 
Reference data collected during the EPMA and LA-ICP-MS analyses are presented in the supplementary information files (see S12 and S13: Analytical Precision). Lipari obsidian and BHVO-2G and show accuracies of typically $\pm 1 \%$ with precision varying, as is expected, with concentration between $\pm 1 \%$ for $\mathrm{SiO}_{2}$ (at $75.17 \mathrm{wt} \%$ ) to $\pm 8 \%$ for $\mathrm{MgO}(0.04 \mathrm{wt} \%$ ) in the Lipari obsidian. For LA-ICP-MS, analyses of ATHO-G show accuracy typically in the $\pm 2-5 \%$ range and precision was generally better than $\pm 10 \%$. Again, there is a general improvement in precision with element and analyte isotope abundance (see Pearce et al., 2004A; 2011).

\section{Volcanic provenance and identification of tephra layers using glass shard composition} (1)

For the seven Icelandic volcanic centres which have erupted during the Holocene, we use a combination of both the major and trace element composition of their associated tephra deposits to establish key criteria for their recognition, discrimination, and provenance. These approaches can be used to identify tephra sourced from different systems as well as discriminating between tephra sourced from within one system (e.g. Lowe et al., 2017).

Tephrochronological studies typically identify and correlate tephra layers by plotting new geochemical data onto bivariate plots to compare with previously known tephra data. For many Icelandic tephras, their identification by these approaches is very well established. We do not offer a new method for tephra identification in this paper; we do, however, present our preferred criteria, namely bivariate and ratio plots to best identify the Icelandic tephra layers presented in this catalogue. Figure 6 shows the sequence for discriminating between the seven Holocene Icelandic silicic volcanic centres Hekla, Askja, Öræfajökull, Katla, Torfajökull, Eyafjallajökull and Snæfellsjökull. Initially, the volcanic centres can be separated into high and low alkali groups based on their (normalised) glass shard $\left(\mathrm{Na}_{2} \mathrm{O}+\mathrm{K}_{2} \mathrm{O}\right)$ v. $\mathrm{SiO}_{2}$ contents on a total alkalis-silica (TAS) diagram. The low alkali group has $\mathrm{Na}_{2} \mathrm{O}+\mathrm{K}_{2} \mathrm{O}$ concentrations of $<8.25 \%$ and includes Hekla, Askja and Katla, and can be further separated using glass $\mathrm{FeO}$ and $\mathrm{TiO}_{2}$ concentrations. The high alkali group has $\mathrm{Na}_{2} \mathrm{O}+\mathrm{K}_{2} \mathrm{O}$ concentrations of $>8.25 \%$ and includes Öræfajökull, Torfajökull, Eyafjallajökull and Snæfellsjökull eruptives. They can be separated using their $\mathrm{FeO}$ and $\mathrm{K}_{2} \mathrm{O}$ contents with the slight overlap between Eyafjallajökull and Snæfellsjökull here being eliminated using $\mathrm{FeO}$ and $\mathrm{MgO}$ contents. Data 
presented for Eyafjallajökull and Snæfellsjökull are sourced from Larsen et al. (1999, 2002). The Eyafjallajökull samples were also analysed using EPMA in Edinburgh making them directly comparable to the samples analysed in this paper.

Figure 7 is a flow diagram that uses trace element chemistry to identify the main Icelandic silicic volcanic centres Hekla, Askja, Öræfajökull, Katla, and Torfajökull. Once a volcanic system is identified, it is not incorporated into the subsequent plot. This elimination procedure allows for a straightforward sequence to discriminate between tephra data sets and establish the likely provenance of tephra layers. An initial trace element ratio of $\mathrm{Zr} / \mathrm{Nb}$ plotted against $\mathrm{Ba} / \mathrm{Sr}$ immediately isolates the Torfajökull (medium $\mathrm{Zr} / \mathrm{Nb}$ and $\mathrm{Ba} / \mathrm{Sr}$ values) and Öræfajökull (high Zr/Nb and high Ba/Sr values) volcanic centres because the Hekla, Askja and Katla systems show low $\mathrm{Ba} / \mathrm{Sr}$ concentrations. Plotting $\mathrm{Ba} / \mathrm{Sr}$ against $\mathrm{Nb}$ then allows for the separation of the Katla (high Nb), Askja (low Nb) and Hekla (medium Nb and a range of $\mathrm{Ba} / \mathrm{Sr}$ values) tephra layers. Eyafjallajökull and Snæfellsjökull were not sampled as part of this project, and no trace element data are currently available for the eruptives from these volcanic centres.

Identification of individual tephra layers from within the same volcanic system using glass shard composition

Individual volcanic centres can be identified using a combination of $\mathrm{TAS}, \mathrm{FeO}, \mathrm{TiO}_{2}, \mathrm{~K}_{2} \mathrm{O}$ and $\mathrm{MgO}$ concentrations and selected trace element ratios such as $\mathrm{Zr} / \mathrm{Nb}$ and $\mathrm{Ba} / \mathrm{Sr}$ (Figs 6 and 7). This section highlights which bivariate and ratio plots best discriminate between eruptive units sourced from within individual volcanic centres focussing on widespread eruptions from Hekla, Katla and Torfajökull.

Discrimination of Hekla tephra layers: major and trace element glass shard compositions

The sequence of plots used for discriminating between the main silicic Hekla layers ( $\mathrm{H} 1104$, $\mathrm{H} 3, \mathrm{HS}, \mathrm{H} 4$ and $\mathrm{H} 5$ ) using major element chemistry is shown in Figure 8. Plotting the analyses of glass shards from the tephra layers onto an initial bivariate plot of $\mathrm{SiO}_{2}$ against $\mathrm{FeO}$ enables 
the layers to be separated into two distinct groups. Group 1 contains the H4 and H5 tephra layers which generally show very highly evolved $\mathrm{SiO}_{2}$ concentrations (71.25-77.19 wt. \%) and particularly low FeO concentrations (1.45-4.16 wt. \%). Group 2 contains the H1104, H3, and $\mathrm{HS}$ tephra layers. The $\mathrm{H} 3$ and $\mathrm{HS}$ tephras show a broad range of $\mathrm{SiO}_{2}$ compositions $(62.10-$ 75.19 wt. \%) along with a wide range of FeO concentrations (1.05-10.07 wt. \%).

Generally, the H4 and H5 tephra layers show near-identical major element geochemical patterns, but minor variations in $\mathrm{FeO}$ and $\mathrm{TiO}_{2}$ concentrations allow for these elements to be used as discriminators. A small amount of data overlap does still remain between the two layers. It must also be noted that the values for $\mathrm{FeO}$ and $\mathrm{TiO}_{2}$ are close to precision levels, and therefore may cause possible ambiguity when analysing distal shards. The H1104, H3 and HS tephra layers show very similar geochemical signatures but there are minor differences in major element compositions between the three layers. The H3 and HS tephra layers are stratigraphically adjacent but show minor variations in $\mathrm{MgO}$ and $\mathrm{FeO}$ which are best recognised when plotted as $\mathrm{Mg \#}\left[\mathrm{Mg \#}=\mathrm{MgO}_{\mathrm{wt} . \%} /\left(\left(\mathrm{MgO}_{\mathrm{wt} . \%} / \mathrm{MgO}_{\mathrm{mol}}\right)+\left(\mathrm{FeO}_{\mathrm{wt}} \% / \mathrm{FeO} \mathrm{mol}\right)\right)\right]$ against $\mathrm{CaO}$ concentrations. HS shows overall higher $\mathrm{Mg \#}(0.05-0.10)$ and lower $\mathrm{CaO}$ values (1.96-3.62 wt. \%) whereas $\mathrm{H} 3$ shows an overall lower Mg\# (0.03-0.12) and higher $\mathrm{CaO}$ concentrations (1.47-4.99 wt. \%). The silicic component of the H3 tephra shows a range of $\mathrm{SiO}_{2}$ concentrations (62.10-75.19 wt. \%) although the $\mathrm{SiO}_{2}$ range for the $\mathrm{H} 1104$ tephra layer is much narrower (72.21-73.39 wt. \%). The more rhyolitic compositions of the $\mathrm{H} 1104$ and $\mathrm{H} 3$ tephra layers remain practically identical; however, Figure 8 highlights slightly increased $\mathrm{K}_{2} \mathrm{O}$ concentrations (2.61-4.96 wt. \%) in the $\mathrm{H} 1104$ tephra layer when compared with $\mathrm{K}_{2} \mathrm{O}$ concentrations (1.08-3.05 wt. \%) in $\mathrm{H} 3$. The different ranges of $\mathrm{K}_{2} \mathrm{O}$ allows for differentiation of the two tephra layers although a marked data overlap remains. If only a few shards were available (e.g. from a cryptotephra) then $\mathrm{K}_{2} \mathrm{O}$ would not be a reliable means to separate the two tephra layers without additional information.

Complications arise when the HA-HB-HC-HM-HN-HX-HY-HZ tephra layers are added to Figure 8. The silicic components of the tephra layers show a wide range of $\mathrm{SiO}_{2}$ concentrations (60.03-75.14 wt. \%) with the higher $\mathrm{SiO}_{2}$ end-members showing consistent overlap with $\mathrm{H3}$ and $\mathrm{H} 1104$. The lower $\mathrm{SiO}_{2}$ end-members do create a distinctive (yet widely scattered) third group on Figure 8 with apparently lower $\mathrm{Na}_{2} \mathrm{O}+\mathrm{K}_{2} \mathrm{O}$ values than the more widely dispersed tephra layers (such a pattern relates to lower $\mathrm{SiO}_{2}$ values), but differentiation within the group 
itself is not possible because the major element data for each layer shows significant overlap. The tephra layers also show very similar physical characteristics at proximal locations, their only distinguishing features being their direction of deposition relative to the Hekla central volcano (Fig. 9) and their stratigraphic relationships within the sub-groups: HA-HB-HC; HM$\mathrm{HN}$; and $\mathrm{HX}-\mathrm{HY}-\mathrm{HZ}$ (Fig. 4). Further information on these tephra layers is available in the supplementary information.

Differentiation of the Hekla silicic tephra layers using trace element data is presented in Figure 10. Plotting trace element ratios of $\mathrm{Ba} / \mathrm{Zr}$ against $\mathrm{Ce} / \mathrm{Y}$ separates the major Hekla layers almost immediately. The overlap between the $\mathrm{H} 4$ and $\mathrm{H} 5$ tephra layers is lost because of the higher $\mathrm{Ba} / \mathrm{Zr}$ values of $\mathrm{H} 5$ relative to $\mathrm{H} 4$. The $\mathrm{HS}$ tephra layer is easily separated from $\mathrm{H} 3$ and $\mathrm{H} 1104$ because of its particularly low $\mathrm{Ba} / \mathrm{Zr}$ values. A small overlap between $\mathrm{H} 3$ and $\mathrm{H} 1104$ does still remain, but this is notably reduced in comparison with that in Figure 8.

The less wide-spread Hekla layers (HA-HB-HC-HM-HN-HX-HY-HZ) plot onto Figure 10 as a mostly separate group with low $\mathrm{Ba} / \mathrm{Zr}$ values. There are, however, some analyses that consistently overlap the $\mathrm{H} 1104, \mathrm{H} 3, \mathrm{HS}, \mathrm{H} 4$ and $\mathrm{H} 5$ tephra layers. It is possible that these analyses either represent a very small fraction of highly evolved silicic magma within these eruptives, or they represent syn-eruptive inclusion of glass shards from the earlier $\mathrm{H} 5, \mathrm{H} 4, \mathrm{HS}$ and $\mathrm{H} 3$ eruptions, therefore demonstrating contamination of the tephra layers. If the analyses are a true reflection of the geochemistry of the HA-HB-HC-HM-HN-HX-HY-HZ layers, then these analyses must be considered when correlating tephras at distal locations. Tephra layers identified and correlated based on analyses of only a few shards, could perhaps be misidentified as the more widespread $\mathrm{H} 3, \mathrm{HS}, \mathrm{H} 4$, and $\mathrm{H} 5$ tephras when in actual fact they might represent the HA-HB-HC-HM-HN-HX-HY-HZ layers. Although at present the HA-HB-HC-HM$\mathrm{HN}-\mathrm{HX}-\mathrm{HY}-\mathrm{HZ}$ tephra layers have not been identified in sequences beyond Iceland, we should be mindful that small scale-eruptions can spread tephra across wide areas of the North Atlantic - as exemplified by the 2010 eruption of Eyjafjallajökull. In this regard, attention to stratigraphic relationships and ages should support geochemical identification as the HA-HBHC-HM-HN-HX-HY-HZ layers are younger and thus stratigraphically above the H3, HS, H4, and H5 tephras. 
Holocene eruptions from the Torfajökull volcanic system are represented by two tephra layers studied here: Landnám (also known as the Settlement layer; 1123 b2k) and Grákolla (2200 b2k). Both are silicic in composition and show similar major element compositions. The layers can be partially separated using major element data, particularly via $\mathrm{FeO}$ as the Landnám tephra shows slightly lower concentrations (1.94-2.76 wt. \%) compared to those of the Grákolla tephra (2.21-3.06 wt. \%); however there is a consistent overlap in the major element data (Fig. 11). Plotting trace element data allows for much clearer differentiation between the layers with $\mathrm{Y}$ and $\mathrm{Zr}$ showing that the Landnám tephra has higher concentrations $(Y=52.17-94.43 \mathrm{ppm} ; \mathrm{Zr}=596.90-989.60 \mathrm{ppm})$ of both elements compared to those of Grákolla ( $\mathrm{Y}=42.90-67.45$ ppm; $\mathrm{Zr}=369.25-604.39$ ppm) (Fig. 11). Their $\mathrm{Zr} / \mathrm{Y}$ ratios, however, are similar, which is consistent with their co-genetic origin. As with the Hekla layers, it is important to understand the stratigraphy of tephra layers from Torfajökull. The Landnám tephra is 1123 years b2K and is widely identified across the North Atlantic. The Grákolla tephra is 2200 b2k and currently has not been identified in sequences outside Iceland. As in all tephra studies, details of the stratigraphic and age relationships at distal localities are of great importance to ensure any potential occurrences of the Grákolla tephra are not missed, nor misidentified as Landnám.

Discrimination of Katla tephra layers: major and trace element glass shard compositions

The Katla volcanic system has erupted several silicic tephra layers including SILK UN, YN, LN and MN. The SILK UN and LN layers were sampled and analysed as part of this project. Additional major element data for all four layers are taken from Larsen et al. (2001) and Dugmore (2000). Glass analyses of the SILK UN tephra can consistently be separated from those of the other tephra layers using a range of major element plots (e.g. $\mathrm{MgO} \vee \mathrm{TiO}_{2}$; Fig. 12). The SILK UN tephra shows systematically higher $\mathrm{MgO}$ and $\mathrm{TiO}_{2}$ values $(\mathrm{MgO}=1.27-1.42$ wt. \%; $\mathrm{TiO}_{2}=1.28-1.45$ wt. \%) than those of the other SILK tephra layers (MgO $=0.54-1.23$ wt.\%; TiO2 = 0.95-1.31 wt. \%). The SILK LN, MN, and YN layers show consistent overlap of their major element chemistries. Trace element data have been collected for the UN and LN layers, and these can be separated by plotting $\mathrm{Y}$ against Ce (Fig. 12), although data are limited. 
1 The UN layer shows a smaller range in Y values (66.7-84.6 ppm) compared to that of LN (63.5$93.2 \mathrm{ppm})$, and these values are also useful when plotted against Ce concentrations for both layers. Other trace element plots, however, show some overlap between these two layers (UN and LN). Undoubtedly the addition of trace element data for the MN and YN tephra layers would assist in identifying individual tephra layers from the Katla system and this approach should be a priority for any future work.

\section{Conclusions}

The data presented in this paper are the first catalogue of high quality major and trace element analyses collected for glass from Holocene silicic tephra layers sourced from seven Icelandic volcanic centres at proximal reference locations. Most of the tephra layers are widespread, established tephra marker horizons for the North Atlantic region. Other tephra layers included in the catalogue of analyses are less widespread and currently only recognised in the proximal record. The data show that major and trace element compositions can be used to establish tephra provenance and in most instances can also be used to identify and discriminate between tephra layers sourced from within the same volcanic system.

Systematic comparisons with the data and criteria presented here to discriminate between these layers should support distal tephrochronological studies in identifying and correlating cryptotephra horizons. The provision of data from recognised layers and localities in proximal locations in Iceland will reduce the need to identify and correlate new tephra finds to distal tephra occurrences. This development in turn will limit the possibility for tephra misidentifications to persist into future studies. The inclusion of different eruption phases and chemistries from each tephra layer may also provide potential for correlations with distal tephra layers without a known source.

The catalogue in its current format, however, is incomplete. Analysis and compilation of more stratigraphically constrained tephra layers, both widespread and not, from every volcanic system in Iceland would improve the quality of the catalogue and would provide a real opportunity to understand the extensive Icelandic contribution to North Atlantic tephrostratigraphy. 


\section{Acknowledgements}

3 The authors would like to acknowledge and thank the following for their support. Margaret

\section{References}

Abbott, P., Bourne, A. J., Purcell, C. S., Davies, S. M., Scourse, J. D. And Pearce, N. J. G. 2016. Last glacial period cryptotephra deposits in an eastern North Atlantic marine sequence: exploring linkages to the Greenland ice-cores. Quaternary Geochronology 31: 62 - 76.

Abbott, P., Griggs, A. J., Bourne, A. J., Chapman, M. R. And Davies, S. M. (2018) Tracing marine cryptotephras in the North Atlantic during the last glacial period: Improving the North Atlantic marine tephrostratigraphic framework. Quaternary Science Review 189: 169 - 186.

BaniK, T., Miller, C. F., Fisher, C. M., Coble, M. A. AND Vervoort, J. D. 2018. Magmatic-tectonic control on the generation of silicic magmas in Iceland: Constraints from Hafnarfjall-Skarđsheiði volcano. Lithos 318-319: 326 - 339.

BAsile, I., Petit, J. R., Touron, S., Grousset, F. E. ANd BARKov, N. 2001. Volcanic layers in Antarctic (Vostok) ice cores: Source identification and atmospheric implications. Journal of Geophysical Research 106(D23): 31,915 - 31,931.

BEGÉT, J. E.. AND KESKINEN, M. J. 2003. Trace-element geochemistry of individual glass shards of the Old Crow tephra and the age of the Delta glaciation, central Alaska. Quaternary Research 60: 63 69.

BenNetT, K. D., Boreham, S., SHARP, M. J., AND SWITSUR, V. R. 1992. Holocene history of environment, vegetation and human settlement on Catta Ness, Lunnasting, Shetland. Journal of Ecology 80(2): $241-273$. 
Bergman, J., Wastegård, S., Hammarlund, D., Wohlfarth, B. ANd Roberts, S.J. 2004. Holocene tephra horizons at Klocka Bog, west-central Sweden: aspects of reproducibility in subarctic peat deposits. Journal of Quaternary Science 19(3): 241 - 249.

Bindeman, I., Gurenko, A., Carley, T., Miller, C., Martin, E. And Sigmarsson, O. 2012. Silicic magma petrogenesis in Iceland by remelting of hydrothermally altered crust based on oxygen isotope diversity and disequilibria between zircon and magma with implications for MORB. Terra Nova 24(3): $227-232$.

BLACKFORD, J. J., EDWARDS, K. J., DUGMORE, A. J., COOK, G. T. AND BUCKLAND, P. C. 1992. Icelandic volcanic ash and the mid-Holocene Scots pine (Pinus sylvestris) pollen decline in northern Scotland. The Holocene 2(3): $260-265$.

BoYGLE, J. 1998. A little goes a long way: discovery of a new mid-Holocene tephra in Sweden. Boreas 27: $195-199$.

BOYGLE, J. 2004. Towards a Holocene tephrochronology for Sweden: geochemistry and correlation with the North Atlantic tephrastratigraphy. Journal of Quaternary Science 19: $103-109$.

BryANT, C. J., ARCULUS, R. J. AND EgGINS, S. M. 1999. Laser ablation-inductively coupled plasma-mass spectrometry and tephras: A new approach to understanding arc-magma genesis. Geology 27(12): $1119-1122$.

BUCKLAND, P. C., DUGMORE, A. J. AND EDWARDS, K. J. 1997. Bronze Age myths? Volcanic activity and human response in the Mediterranean and North Atlantic regions. Antiquity 71: 581 - 593.

Caseldine, C., Hatton, J., Huber, U., Chiverrell, R. And Woolley, N. 1998. Assessing the impact of volcanic activity on mid-Holocene climate in Ireland: the need for replica data. The Holocene 8: 105 111.

Chambers, F. M., Daniell, J. R. G., Hunt, J. B., Molloy, K. And O'Connel, M. 2004. Tephrostratigraphy of An Loch Mór, Inis Oírr, western Ireland: implications for Holocene tephrochronology in the northeastern Atlantic region. The Holocene 14(5): 703 - 720.

CHARMAN, D. J., WEST, S. AND KELLY, A. 1995. Environmental change and tephra deposition: the STrath of Kildonan, Northern Scotland. Journal of Archaeological Science 22: 799 - 809.

Cook, E., Davies, S. M., GuĐmundsdóttiR, E. R., Abbott, P. M. and Pearce, N. J. G. 2018. First identification and characterization of Borrobol-type tephra in the Greenland ice cores: new deposits and improved age estimates. Journal of Quaternary Science 33(2): 212 - 224. 
DAVIES, S. M., Hoek, W. Z., Bohncke, S. J. P. AND PYNe-O'DonNel, S. 2005. Detection of Late-glacial distal tephra in the Netherlands. Boreas 34: $123-135$.

Davies, S. M., Elmquist, M., Bergman, J., Wohlfarth, B. And Hammarlund, D. 2007. Cryptotephra sedimentation processes within two lacustrine sequences from west central Sweden. The Holocene 17(3): $319-330$.

Davies, S. M., Larsen, G., Wastegård, S., Turney, C. S. M., Hall, V. A., Coyle, L. and Thordarson, Th. 2010. Widespread dispersal of Icelandic tephra: how does the Eyjafjöll eruption of 2010 compare to past Icelandic events? Journal of Quaternary Science 25(5): 605 - 611.

Dörfler, W., Feeser, I., van den Bogaard, C., Dreibort, S., Erlenkeuser, H., Kleinmann, A., Merkt, J. and Wiethold, J. 2012. A high-quality annually laminated sequence from Lake Belau, Northern Germany: Revised chronology and its implications for palynological and tephrochronological studies. The Holocene: $1-14$.

DUGMORE, A. 1989. Icelandic volcanic ash in Scotland. Scottish Geographical Magazine 105(3): 168 172.

DUGMORE, A. J. AND NEWTON, A. J. 1992. Thin tephra layers in peat revealed by X-radiography. Journal of Archaeological Sciences 19: 163 - 170.

Dugmore, A. J, Larsen, G. AND Newton, A. J. 1995A. Seven tephra isochrones from Scotland. The Holocene 5: $257-266$.

Dugmore, A. J., Shore, J. S., Cook, G. T., Newton, A. J., Edwards, K. J. And LarSen, G. 1995b. The radiocarbon dating of Icelandic tephra layers in Britain and Iceland. Radiocarbon 37(2): 379 388.

DUGMORE, A.J. AND NEWTON, A.J. 1996. Ideas and evidence from studies of tephra in The Outer Hebrides: the last 14,000 years (ed. D.D. Gilbertson, M. Kent and J.P. Grattan), Sheffield Academic Press, Sheffield p.45-51

DugmoRe, A. J. AND NeWTON, A. J. 1998. Holocene tephra layers in the Faroe Islands. Fródskaparrit 46: $191-204$.

Dugmore, A. J., NeWton, A. J., LARSEN, G. AND Cook, G. T. 2000. Tephrochronology, environmental change and the Norse settlement of Iceland. Environmental Archaeology 5: 21 - 34. 
EiríksSON, J., KNUdSEn, K. L., HAfLIdASON, H. AND Heinemeier, J. 2000. Chronology of late Holocene climatic events in the northern North Atlantic based on AMS 14C dates and tephra markers from the volcano Hekla, Iceland. Journal of Quaternary Science 15(6): $573-580$.

Eiríksson, J., LarSen, G., KnUdSen, K., Heinemeier, J. And Símonarson, L. A. 2004. Marine reservoir age variability and water mass distribution in the Iceland Sea. Quaternary Science Reviews 23: $2247-2268$.

Grönvold, K., Óskarsson, K., Johnses, S. J., Clausen, H. B., HAMmer, C. U. Bomd, G. AND BARD, E. 1995. Ash layers from Iceland in the Greenland GRIP ice core correlated with oceanic and land sediments. Earth and Planetary Science Letters 135: 149 - 155.

Gudmundsson, M. T., Thordarson, TH., Höskuldsson, Á., LARSEN, G., BJÖRnson, H., PratA, F. J., OddsSON, B., Magnússon, E., högnadóttir, Th., Peternsen, G., Hayward, C. L., Stevenson, J. A. and JÓNSDÓTTIR, I. 2012. Ash generation and distribution from the April - May 2010 eruption of Eyjafjallajökull, Iceland. Scientific Reports 2(572): 1-12.

HALL, V. A., MCVICKER, S. J. AND PILCHER, J. R. 1994a. Tephra-linked landscape history around 2310 BC in some sites in County Antrim and Down, N. Ireland. Biology and Environment: Proceedings of the Royal Irish Academy 94B: 245 - 253.

HALL, V. A., PLICHER, J. R. AND MCCORMAC, F. G. 1994b. Icelandic volcanic ash and the mid-Holocene Scots pine (Pinus sylvestris) decline in the north of Ireland: no correlation. The Holocene 4(1): 79 83.

HALL, V. A. AND PILCHER, J. R. 2002. Late-Quaternary Icelandic tephras in Ireland and Great Britain: detection, characterisation and usefulness. The Holocene 12(2): $223-230$.

HAYWARD, C. 2012. High spatial resolution electron probe microanalysis of tephras and melt inlcusions without beam-induced chemical modification. The Holocene 22(1): 119-125.

housley, R. A., Gamble, C. S., AND RESET Associates. 2014. Examination of Late Palaeolithic archaeological sites in northern Europe for the preservation of cryptotephra layers. Quaternary Science Reviews 118: 142 - 150.

KRISTJÁnSDÓtTIR, G. B., StOneR, J. S., JenNings, A. E., ANDREWS, J. T. AND GRÖnVOLD, K. 2007. Geochemistry of Holocene cryptotephras from the North Iceland Shelf (MD99-2269): intercalibration with radiocarbon and palaeomagnetic chronostratigraphies. The Holocene 17(2): $155-176$. 
Lacasse, C., Sigurdsson, H., Jóhannesson, H., Paterne, M. And CARey, S. 1995. Source of Ash Zone 1 in the North Atlantic. Bulletin of Volcanology 57: 18-32.

Lane, C. S., Brauer, A., Martín-Puertas, C., Blockley, S. P. E., Smith, V. C. and Tomlinson, E. L. 2015. The late Quaternary tephrostratigraphy of annually laminated sediments from Meerfelder Maar, Germany. Quaternary Science reviews 122: 192 - 206.

LANGDON, P. G. AND BARBER, K. E. 2004. Snapshots in time: precise correlations of peat-based proxy climate records in Scotland using mid-Holocene tephras. The Holocene 14(1): 21- 33.

LARSEN, G. 1981. Tephrochronology by microprobe analysis. In: Self, S. and Sparks, R. S. J. (ritstj.), Tephra Studies, p. 95 - 102. D. Reidel Publishing Company, Dordrecht.

LarSen, G., Dugmore, A. J. AND Newton, A. J. 1999. Geochemistry of historical-age silicic tephras in Iceland. The Holocene 9(4): 463-471.

Larsen, G., Newton, A. J., Dugmore, A. J. and VilmundardóttiR, E. 2001. Geochemistry, dispersal, volumes and chronology of Holocene silicic tephra layers from the Katla volcanic system, Iceland. Journal of Quaternary Science, 16(2): 119-132.

Larsen, G., Eiríksson, J. Knudsen, K. L. and Heinemeier, J. 2002. Correlation of the late Holocene terrestrial and marine tephra markers, north Iceland: implications for reservoir age changes. Polar Research 21(2): $283-290$.

LARSEN, G. AND EIRÍKSSON, J. 2008. Late Quaternary terrestrial tephrochronology of Iceland - frequency of explosive eruptions, type and volume of tephra deposits. Journal of Quaternary Science 23(2): $109-120$.

LARSEN, G., Róbertsdóttir, B. G., Óladóttir, B. A., Eiríksson, J. 2019. A shifting eruption mode of Hekla volcano, Iceland, 3000 years ago: Two-coloured Hekla tephra series, characteristics, dispersal and age (in press).

LAWson, I. T., SWindles, G. T., Plunkett, G. AND GREenberG, D. 2012. The spatial distribution of Holocene cryptotephras in north-west Europe since 7ka: implications for understanding ash fall events from Icelandic eruptions. Quaternary Science Reviews 41: 57 - 66.

Lowe, D. J., Pearce, N. J. G., Jorgensen, M. A., Kuehn, S. C., Tryon, C. A. And Hayward, C. L. 2017. Correlating tephras and cryptotephras using glass compositional analyses and numerical and statistical methods: review and evaluation. Quaternary Science Reviews 175: 1 - 44. 
MARTIN, E. AND SIGMARSSON, O. 2007. Crustal thermal state and origin of silicic magma in Iceland: the case of Torfajökull, Ljósufjöll and Snæfellsjökull volcanoes. Contributions to Mineralogy and Petrology 153: $593-605$.

MARTIN, E. AND SIGMARSSON, O. 2010. Thirteen million years of silicic magma production in Iceland: Links between petrogenesis and tectonic setting. Lithos 116(1-2): $129-144$.

Oldfield, F., Thompson, R., Crooks, P. R. J., Gedye, S. J., Hall, V. A., Harkness, D. D., Housley, R. A., McCormac, F. G., NeWton, A. J., PIlcher, J. R., Renberg, I. AND RICHARdson, N. 1997. Radiocarbon dating of a recent high latitude peat profile: Stor Åmyrân, northern Sweden. The Holocene $7(3): 283-290$.

PAlais, J. M., TAYLOR, K., MAYEWSKI, P. A. AND Grootes, P. 1991. Volcanic ash from the 1362 Öræfajökull eruption (Iceland) in the Greenland Ice Sheet. Geophysical Research Letters 18(7): 1241 1244.

Pearce, N.J.G., Westgate J.A. And Perkins W.T. 1996. Developments in the analysis of volcanic glass shards by Laser Ablation ICP-MS: quantitative and single internal standard-multi-element methods. Quaternary International, 34-36: 213-227.

Pearce, N.J.G., Perkins W.T., Westgate J.A., Gorton M.P., Jackson S.e., Neal C.R. and Chenery S.P. 1997. A compilation of new and published major and trace element data for NIST SRM 610 and NIST SRM 612 glass reference materials. Geostandards Newsletter, 21: 115-144

Pearce N.J.G., Westgate J.A., Perkins W.T., Eastwood W.J. and Shane P. 1999. The application of laser ablation ICP-MS to the analysis of volcanic glass shards from tephra deposits: bulk glass and single shard analysis. Global and Planetary Change, 21: 151-171

Pearce, N. J. G., Westgate, J. A., Perkins, W. T. and Preece, S. J. 2004A. The application of ICP-MS methods to tephrochronological problems. Applied Geochemistry 19: 289 - 322.

Pearce, N. J. G., Westgate, J. A., Preece, S. J., Eastwood, W. J. and Perkins, W. T. 2004b. Identification of Aniakchak (Alaska) tephra in Greenalnd ice core challenges the 1645 BC date for Minoan eruption of Santorini. Geochemsitry Geophysics Geosystems 5(3): 1 - 10.

Pearce, N. J. G., Bendall, C. A. And Westgate, J. A. 2008. Comment on "Some numerical considerations in the geochemical analysis of distal microtephra" by A. M. Pollard, S. P. E. Blockley, and C. S. Lane. 2006. Applied Geology 23: $1353-1364$. 
Pearce, N. J. G., Perkins, B., Westgate, J. A. And WAde, S.C. 2011. Trace-element microanalysis by LA-ICPMS: The quest for comprehensive chemical characterisation of single, sub-10 $\mu \mathrm{m}$ volcanic glass shards. Quaternary International, 246(1-2): 57-81.

PEARCE, N. J. G. 2014A. Towards a protocol for the trace element analysis of glass from rhyolitic shards in tephra deposits by laser ablation ICP-MS. Journal of Quaternary Science, 29(7): 627-640.

PeARCE, N. J. G., ABBott, P. M. AND MARTIN-Jones, C. 2014B. Microbeam methods for the analysis of glass in fine grained tephra deposits: a SMART perspective on current and future trends. In Austin, W. E. N., Abbott, P. M., Pearce, N. J. G., and Wastegård, S. (Editors) Marine Tephrochronology, Geological Society Special Publication 398: 29-46.

PILCHER, J. R. AND HALL, V. A. 1996A. Tephrochronological studies in northern England. The Holocene 6(1): $100-105$.

PILCHER, J. R., HALL, V. A. AND MCCORMAC, F. G. 1995. Dates of Holocene eruptions from tephra layers in Irish peats. The Holocene 5: $103-110$.

PILCHER, J. R., HALL, V. A. AND MCCORMAC, F. G. 1996B. An outline tephrochronology for the Holocene of the north or Ireland. Journal of Quaternary Science 11(6): 485 - 494.

Pilcher, J., Bradley, R. S. AND ANDERSON, L. 2005. A Holocene tephra record from the Lofoten Islands, Arctic Norway. Boreas 34: 136 - 156.

Plunkett, G. M., Pilcher, J. R., McCormac, F. G. And HAlL, V. A. 2004. New dates for first millennium BC tephra isochrones in Ireland. The Holocene 14(5): 780 - 786.

Roland, T. P., Caseldine, C. J., Charman, D. J., Turney, C. S. M. And Amesbury, M. J. 2014. WAs the a "4.2 ka event" in Great Britain and Ireland? Evidence from the peatland record. Quaternary Science Reviews 83: $11-27$.

SCHMID, M. M. E., DUgmoRe, A. J., VÉSteinsSOn,O. AND NEWTON, A. J. 2017. Tephra isochrones and chronologies of colonisation. Quaternary Geochronology 40: $56-66$.

SelbekK, R. S. AND TRøNNES, R. G. 2007. The 1362 AD Öræfajökull eruption, Iceland: Petrology and geochemistry of large-volume homogeneous rhyolite. Journal of Volcanology and Geothermal Research 160(1-2): 42 - 58.

Sigmarsson, O., Hémond, C., Condomines, M., Fourcade, S. and Oskarsson, N. 1991. Origin of silicic magma in Iceland revealed by Th isotopes. Geology 19(6): $621-624$. 
SMITH, D. G. W., WESTGATE, J. A. 1968. Electron probe technique for characterising pyroclastic deposits. Earth and Planetary Science Letters 5: $313-319$.

Stivrins, N., Wulfe, S., Wasteg̊̊rd, S., Lind, E. M., AlliksaAr, T., Gatka, M., Andersen, T. J., Heinsalu, A., SEPPÄ, H. AND VESKI, S. 2016. Detection of the Askja AD 1875 cryptotephra in Latvia, Eastern Europe. Journal of Quaternary Science 31: $437-441$.

StREeter, R., DUGMORE, A. J. AND VÉStEInSSON, O. 2012. Plague and landscape resilience in premodern Iceland. PNAS 109(10): $3364-3669$.

SVERRISDOTTIR, G. 2007. Hybrid magma generation preceding Plinian silicic eruptions at Hekla, Iceland: evidence from mineralogy and chemistry of two zoned deposits. Geology Magazine 144(4): $643-659$.

SWINDLES, G. T., PLUNKETT, G. AND RoE, H. M. 2007. A multiproxy climate record from a raised bog in County Fermanagh, Northern Ireland: a critical examination of the link between bog surface wetness and soalr variability. Journal of Quaternary Science 22(7): 667-679.

SWindles, G. T., BLUNDELL, A., RoE, H. M. AND HALL, V. A. 2010. A 4500-year old proxy climate record from the peatlands in the North of Ireland: the identification of widespread summer “drought phases"? Quaternary Science Reviews 29: 1577-1589.

SWindles, G., Galloway, J., Outram, Z., Turner, K., Schofield, J. E., Newton, A. J., Dugmore, A. J., Church, M. J., Watson, E. J., BATt, C., Bond, J., EdWARDS, K. J., TURner, V. AND BAShFord, D. 2013. Re-deposited cryptotephra layers in Holocene peats linked to anthropogenic activity. The Holocene: $1-9$.

THORARINSON, S. 1949. Some tephrochronological contributions to the volcanology and glaciology of Iceland. Geografiska Annaler 31(1-4): 239 - 256.

THORARINSSON, S. 1971. Aldur ljósu gjóskulaganna úr Heklu samkvæmt leiđréttu geislakolstímatali (The age of the light-coloured Hekla tephra layers according to corrected ${ }^{14} \mathrm{C}$ datings). Náttúrufræedingurinn $\mathbf{4 1}$, 99-105.

THORDARSON, T. AND LARSEN, G. 2007. Volcanism in Iceland in historical time: Volcano types, eruptions styles and eruptive history. Journal of Geodynamics 43: 118 - 152.

THORDARSON, T. AND HÖSKULDSSON, Á. 2008. Postglacial volcanism in Iceland. Jökull 58: 197 - 228. 
VAN den BogaARd, C., Dörfler, W., SAndgren, P. ANd Schminke, H.-U. 1994. Correlating the Holocene records: Icelandic tephra found in Schleswig-Holstein (Northern Germany). Naturwissenschaften 81: $554-556$.

van den BogaArd, C., Dörfler, W., Glos, R. Nadeau, M., Grootes, P. M. and Erlenkeuser, H. 2002a. Two tephra layers bracketing late Holocene palaeoecological changes in Northern Germany. Quaternary Research 57: $314-324$.

VAN DEN BogaARd, C. AND SCHMinKe, H-U. 2002b. Linking the North Atlantic to central Europe: a high resolution Holocene tephrochronological record from northern Germany. Journal of Quaternary Science 17(1): 3 - 20.

WallRABe-AdAmS, H-J. AND LACKSCHEWITZ, K. S. 2003. Chemical composition, distribution, and origin of silicic volcanic ash layers in the Greenland-Iceland-Norwegian Sea: explosive volcanism from 10 to $300 \mathrm{ka}$ as recorded in deep-sea sediments. Marine Geology 193: 273 - 293.

WASTEGÅRD, S. 2001. The Mjáuvøtn tephra and other Holocene tephra horizons from the Faroe Islansa: a link between Icelandic source region, the Nordic Seas and the European continent. The Holocene 11(1): $101-109$.

WASTEGÅRD, S. 2005. Late Quaternary tephrochronology of Sweden: a review. Quaternary International 130: $49-62$.

WAStegÅRd, S., Rundgren, M., SCHOning, K., ANDERsson, S., BJÖRK, BorgmaRK, A. AND Possnert, G. 2008. Age, geochemistry and distribution of the mid-Holocene Hekla-S/Kebister tephra. The Holocene 18(4): $539-549$.

WASTEGÅRD, S. AND BoygLE, J. 2012. Distal tephrochronology of NW Europe - the view from Sweden. Jökull 62: $73-80$.

WATSON, E. J., SWINDLES, G. T., LAWSON, I. T. AND SAVOV, I. P. 2016. Do Peatlands or lakes provide the most comprehensive distal tephra records? Quaternary Science Reviews 139: 110-128.

WeLLS, C., HUCKERBY, E. AND HALL, V. 1997. Mid- and late Holocene vegetation history and tephra studies at Fenton Cottage, Lancashire, UK. Vegetation History and Archaeobotany 6: 153 - 166.

WUlf, S., Dräger, N.. OtT, F., Serb, J., Appelt, O., GUĐmundsdóttiR, E., VAN den BogaArd, C., StowińskI, M., BŁASZKIEWICZ, M. AND BRAUER, A. 2016. Holocene tephrostratigraphy of varved sediment records from Lakes Tiefer See (NE Germany) and Czechowskie (N Poland). Quaternary Science Reviews 132: $1-14$. 
1 Zielinski, G. A., Germani, M. S., Larsen, G., Baille, M. G. L., Whitlow, S., TWickler, M. S. AND Taylor, K. C.

2

3

4

5

6

7

8

9

10

11

12

13

14

15

16

17

18

19

12

13

6

8

9 Journal of Geophysical Research 102: 26625 - 26640.

ZILLÉN, L. M., WASTEGÅRD, S. AND SNOWBALL, I. F. 2002. Calendar year ages of three mid-Holocene tephra layers identified in varved lake sediments in west central Sweden. Quaternary Science Reviews 21: $1583-1591$.

\section{(1)}

8

(1)

10

1 


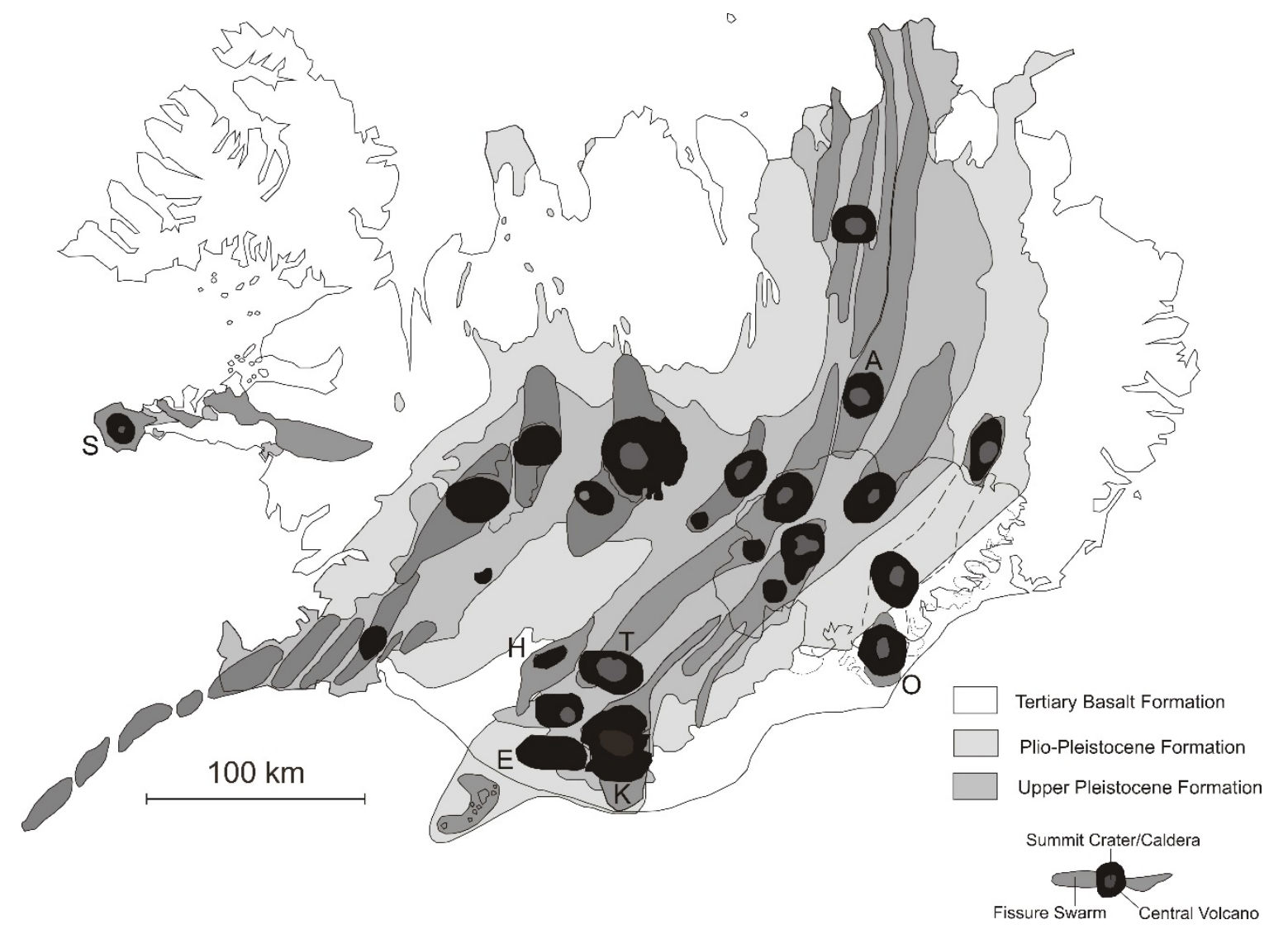

2 Figure 1: Map showing the location and the distribution of the 30 active volcanic systems identified 3 within Iceland superimposed onto the regional geological subdivisions recorded in Iceland. Volcanoes 4 known to have produced silicic magma are labelled Hekla $(H)$, Torfajökull $(T)$, Katla (K), Öræfajökull 5 (O), Askja (A), Snæfellsnes (S) and Eyjafjallajökull (E) (adapted from Thordarson and Larsen, 2007). 


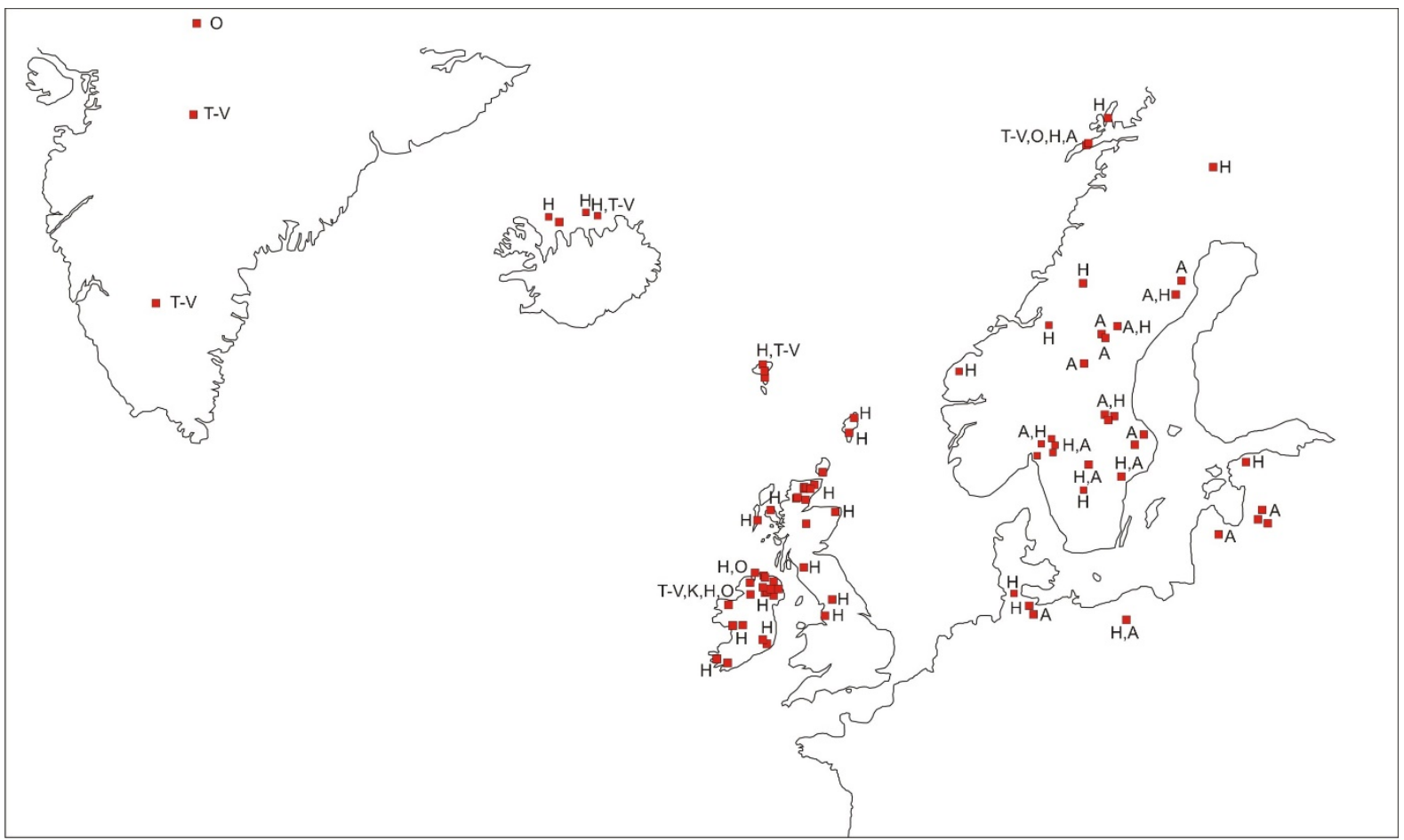

2 Figure 2: Localities across the North Atlantic region where cryptotephra horizons of Icelandic origin 3 have been identified by the community. Localities on the map specifically show where the tephra 4 layers analysed in this paper have been identified. Tephra-derived glass shards have been identified 5 in marine, fluvial, glacial and terrestrial deposits and correlated to Icelandic sources using geochemical analyses. Letters denote which system produced the tephras identified at each location: 0 : Öræfajökull; T-V: Torfajökull-Vatnaöldur; H: Hekla; A: Askja (Dugmore, 1989; Palais et al. 1991; Bennett, 1992; Blackford et al. 1992; Dugmore et al. 1992, 1995a, 1996; Hall et al. 1994a; van den Bogaard et al. 1994, 2002a,b; Charman et al. 1995; Grönvold, 1995; Pilcher et al. 1995, 1996a,b, 2005; Pilcher and Hall, 1996; Oldfield et al. 1997; Wells et al. 1997; Zielinski, 1997; Boygle et al. 1998, 2004; Caseldine et al. 1998; Dugmore and Newton, 1998; Eiríksson et al. 2000, 2004; Wastegård, 2001, 2005; Larsen et al. 2002; Van Den Bogaard and Schminke, 2002; Zillén et al. 2002; Bergman et al. 2004; Chambers et al. 2004; ; Langdon and Barber, 2004; Plunkett et al. 2004; Davies et al. 2007; Kristijansdóttir et al. 2007; Swindles et al. 2007, 2010, 2013; Wastegård et al. 2008; Dörfler et al. 2012; Lawson et al. 2012; Wastegård and Boygle, 2012; Housley, et al. 2014; Roland et al. 2014; Stivrins et al. 2016; Watson et al. 2016; Wulf et al. 2016. 

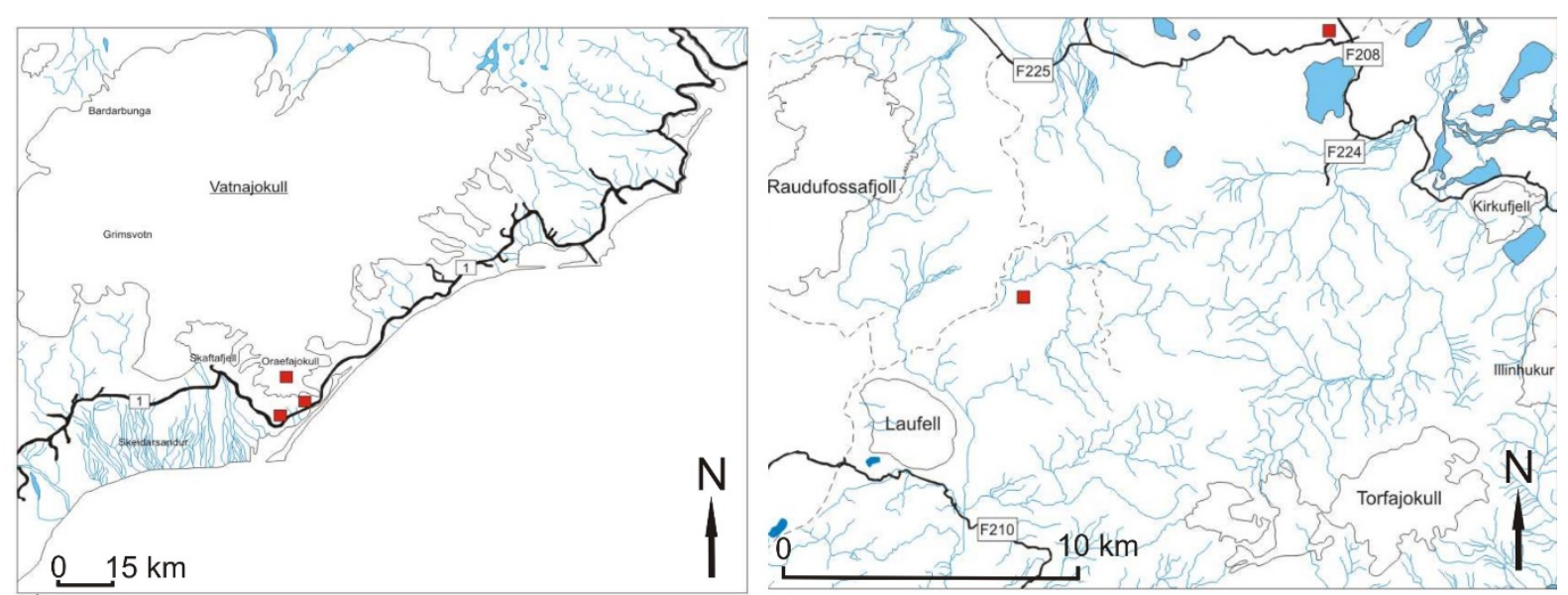

a)

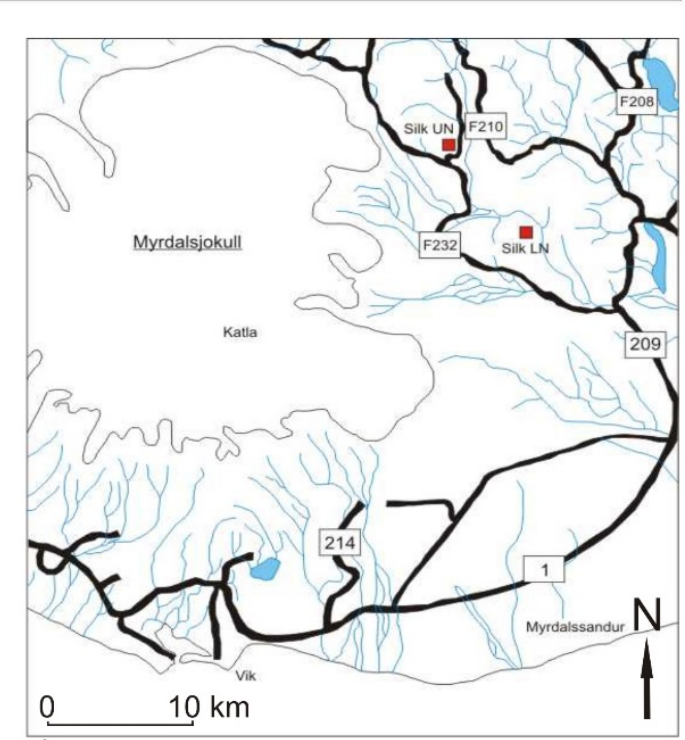

b)

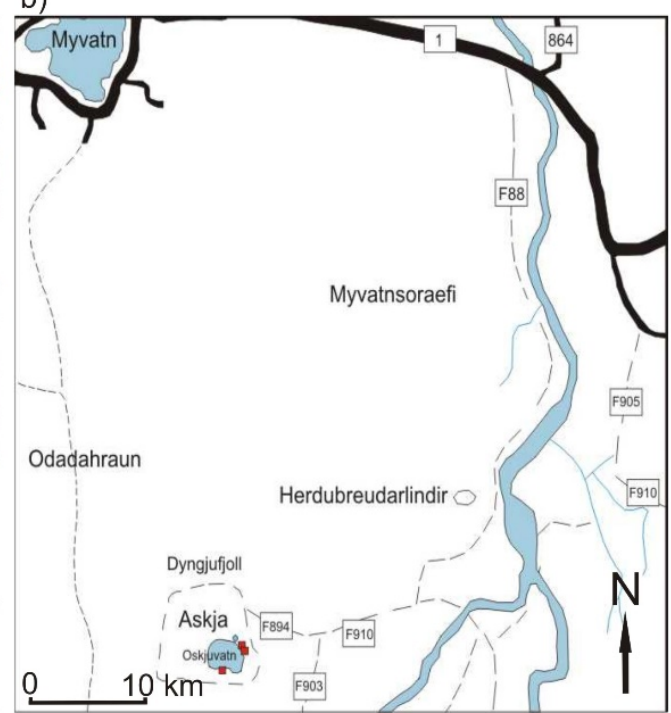

d)

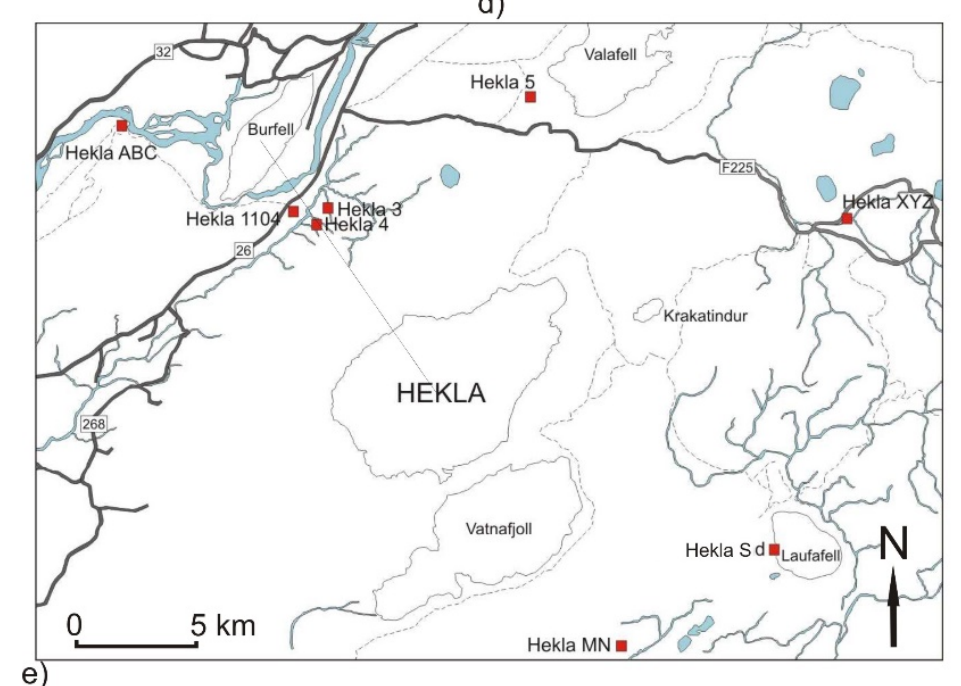

e)

Figure 3: Sampling localities of Holocene silicic layers from (a) Öræfajökull 1362, (b) Torfajökull: Grákolla and Landnám, (c) Katla Silk layers, (d) Askja 1875, (e) Hekla 1104, 3, 4, 5, S, ABC, MN, XYZ. Further information on sampling localities is included in the supplementary information. 


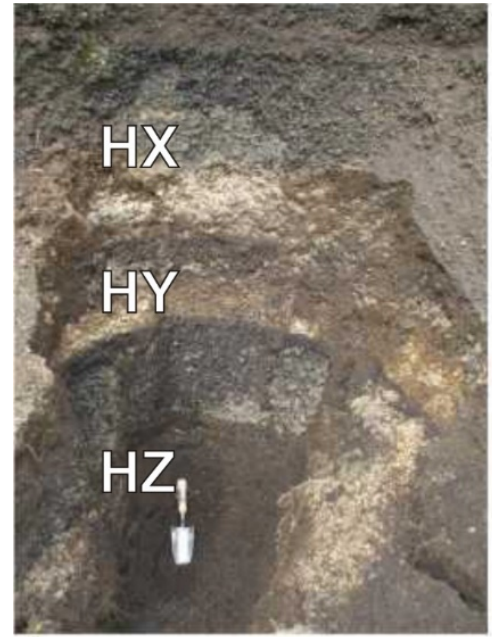

a)

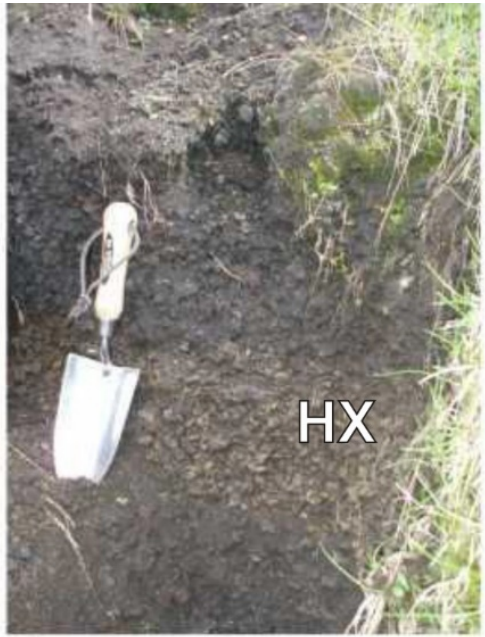

b)

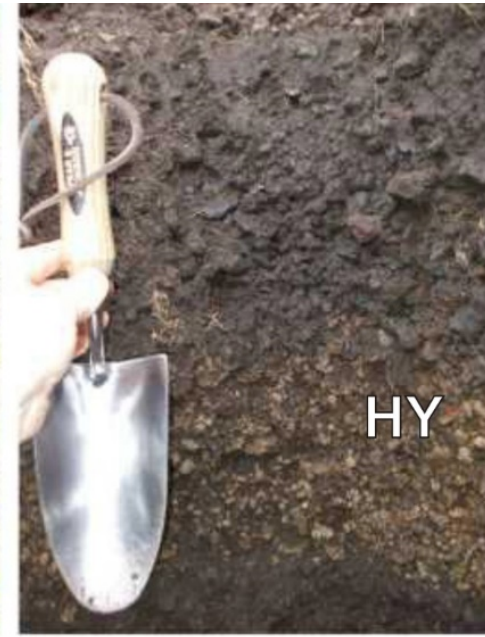

c)

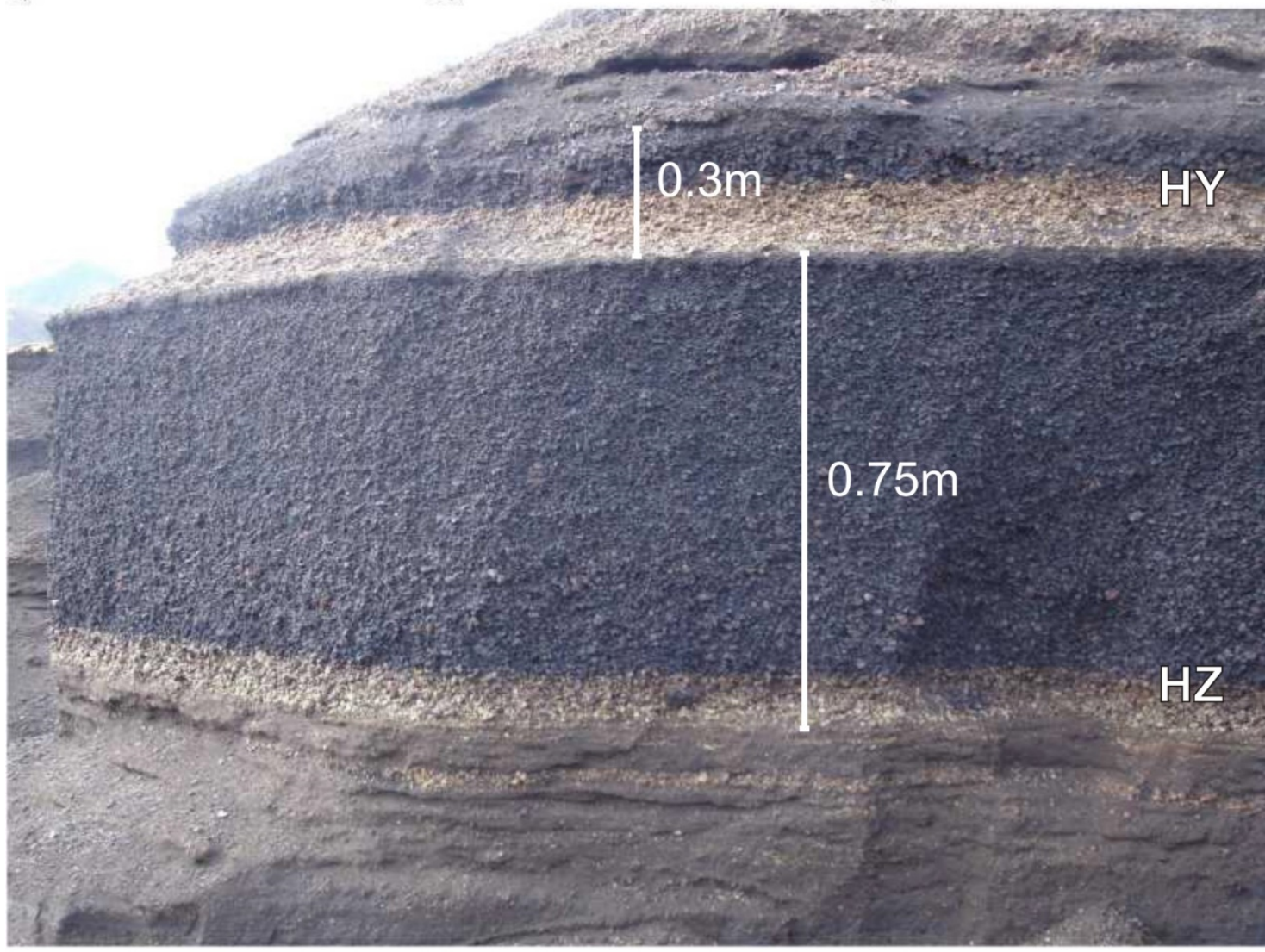

d)

2 Figure 4: $\mathrm{H} \mathrm{X}-\mathrm{Y}-\mathrm{Z}$ tephra layers at the sampling location near Sauđleysur on the banks of the 3 Helliskvísl River and route F225. a) Reference section containing HX at the top, HY in the middle and $\mathrm{HZ}$ at the base of the deposit. b) HX tephra layer. c) HY tephra layer. d) HZ tephra layer on the banks of the Rauđufossakvísl near Sátubarn. Photographs: Rh. Meara (a-c) and K. Roberts (d). 
1

2 Figure 5: Pumice sample from the Grákolla tephra layer showing magma mingling between silicic and 3

4

5

6

7

8

9

10

11

12

13

14

15

16

17

mafic components. Pen lid for scale. Photograph: Rh. H. Meara

.

列

6

.

8

(

(1)

12

14

15

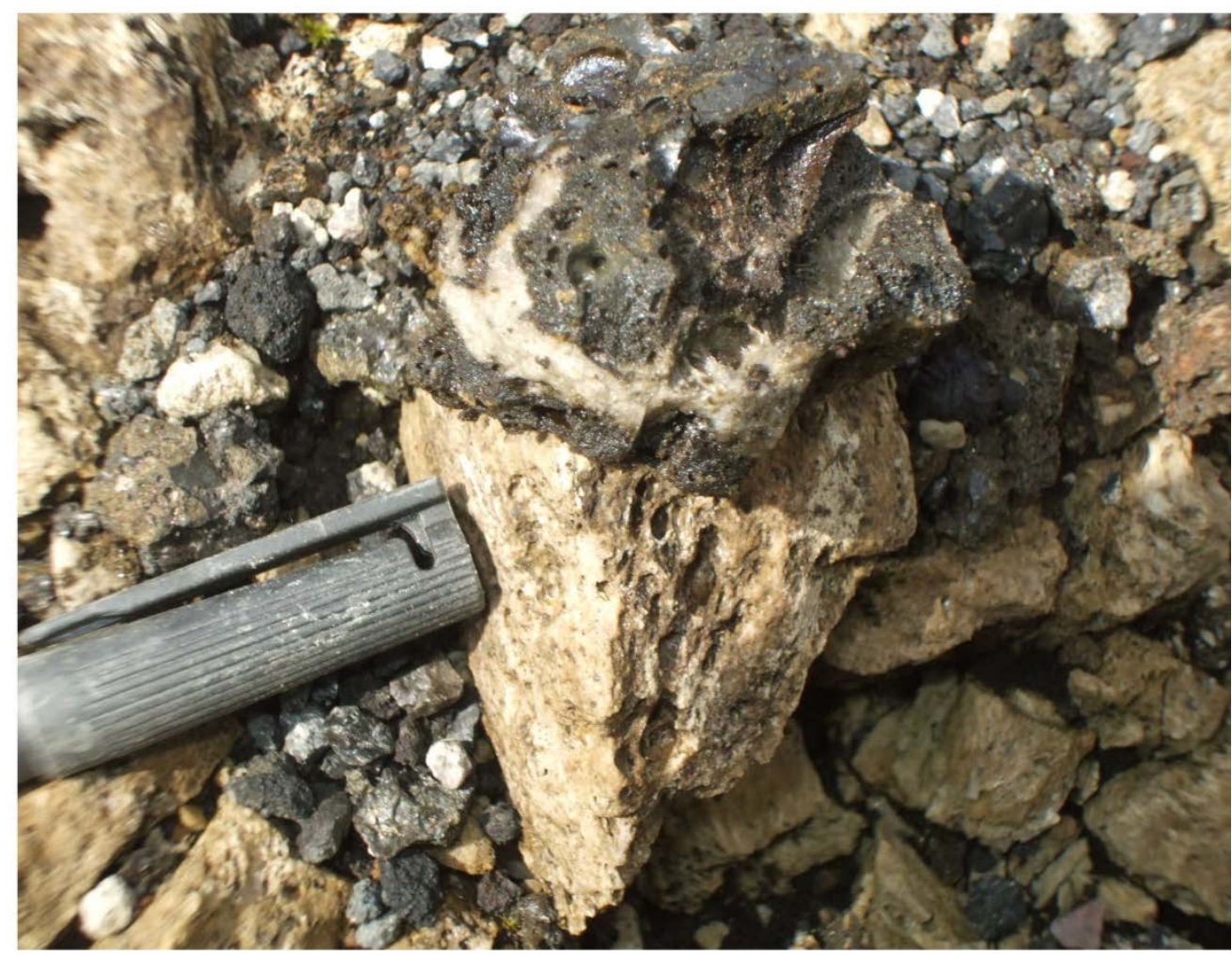




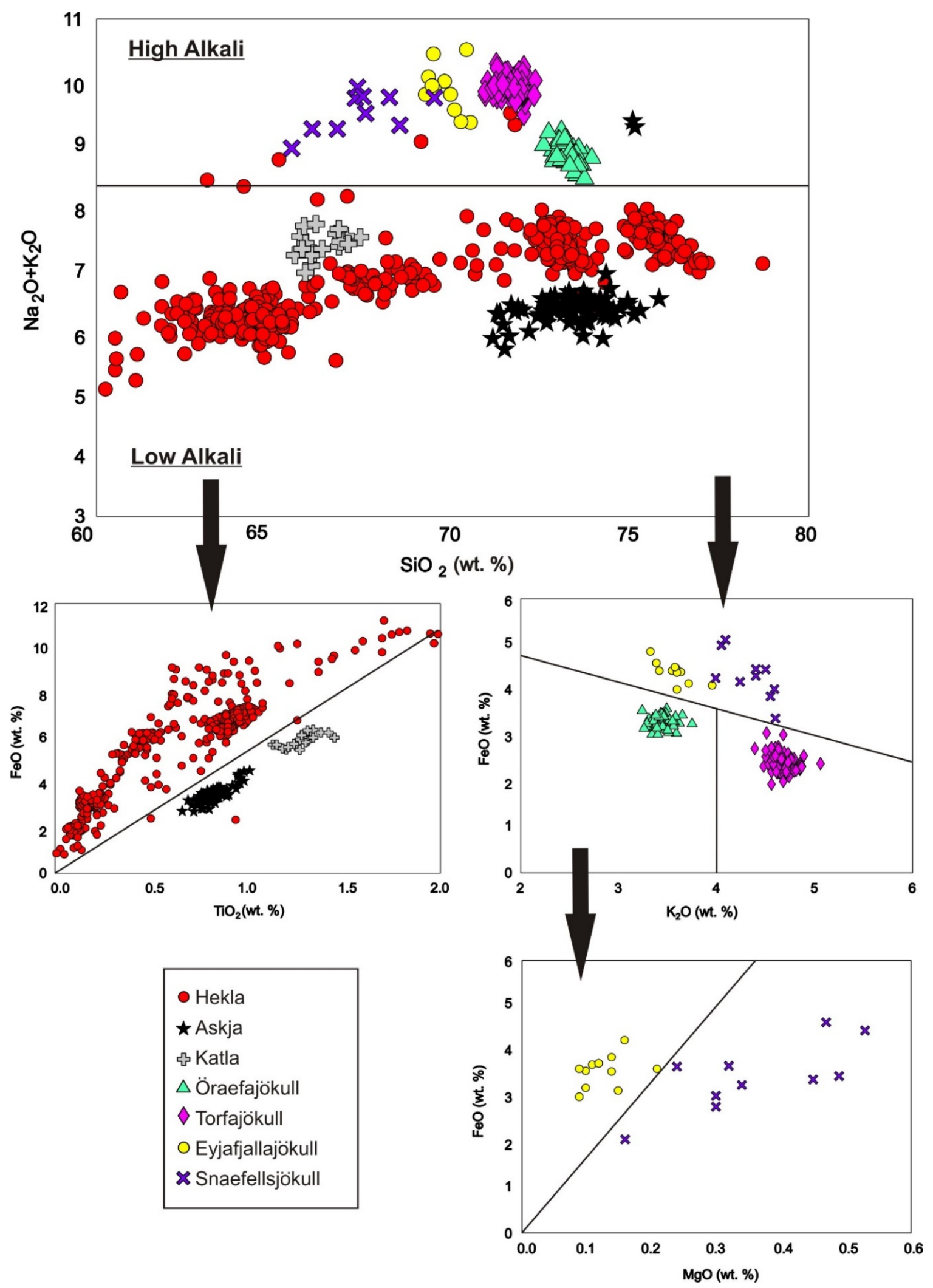

Figure 6: Total alkali silica plot of the Icelandic volcanic systems Hekla, Askja, Katla, Öræfajökull, 3 Torfajökull, Eyjafjallajökull and Snaefellsjökull. Data for Eyjafjallajökull are sourced from Larsen et al. 4 (1999) and data for Snæfellsjökull are sourced from Larsen et al. (2002). All analyses are normalised 5 (presented on an anhydrous basis). 


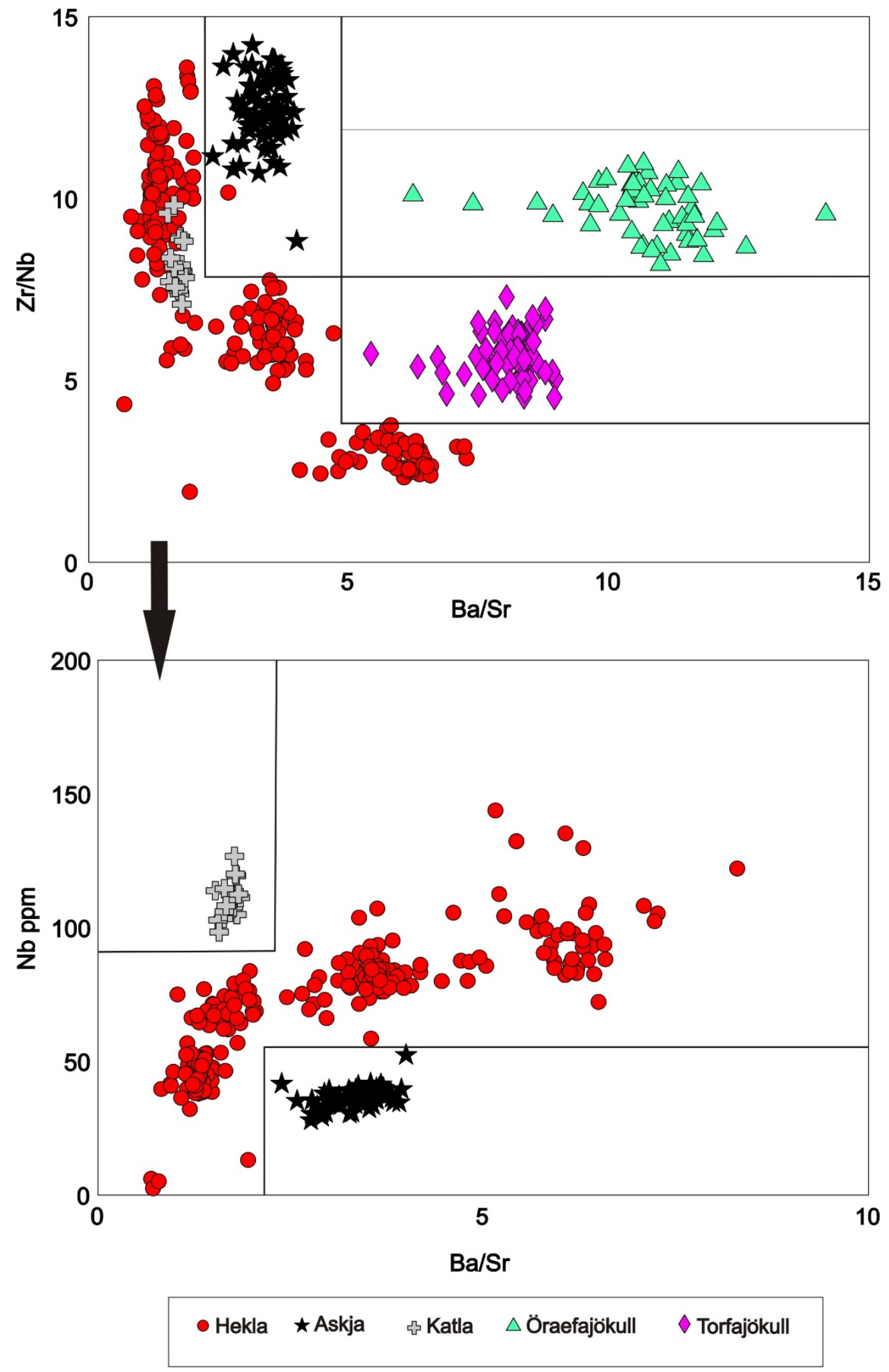

2 Figure 7: Bivariate plots of trace and rare earth element combinations for the Hekla, Askja, Katla, 3 Öræfajökull, and Torfajökull volcanic systems. Plotting trace element ratios allows for swift 4 discrimination of the volcanic centres. Ba/Sr values are highest in Öræfajökull and Torfajökull tephras 5 which in turn can be separated by $\mathrm{Zr} / \mathrm{Nb}$ values. Variation is $\mathrm{Nb}$ concentrations also allows for 6 discrimination between the Hekla, Askja and Katla volcanic systems. 


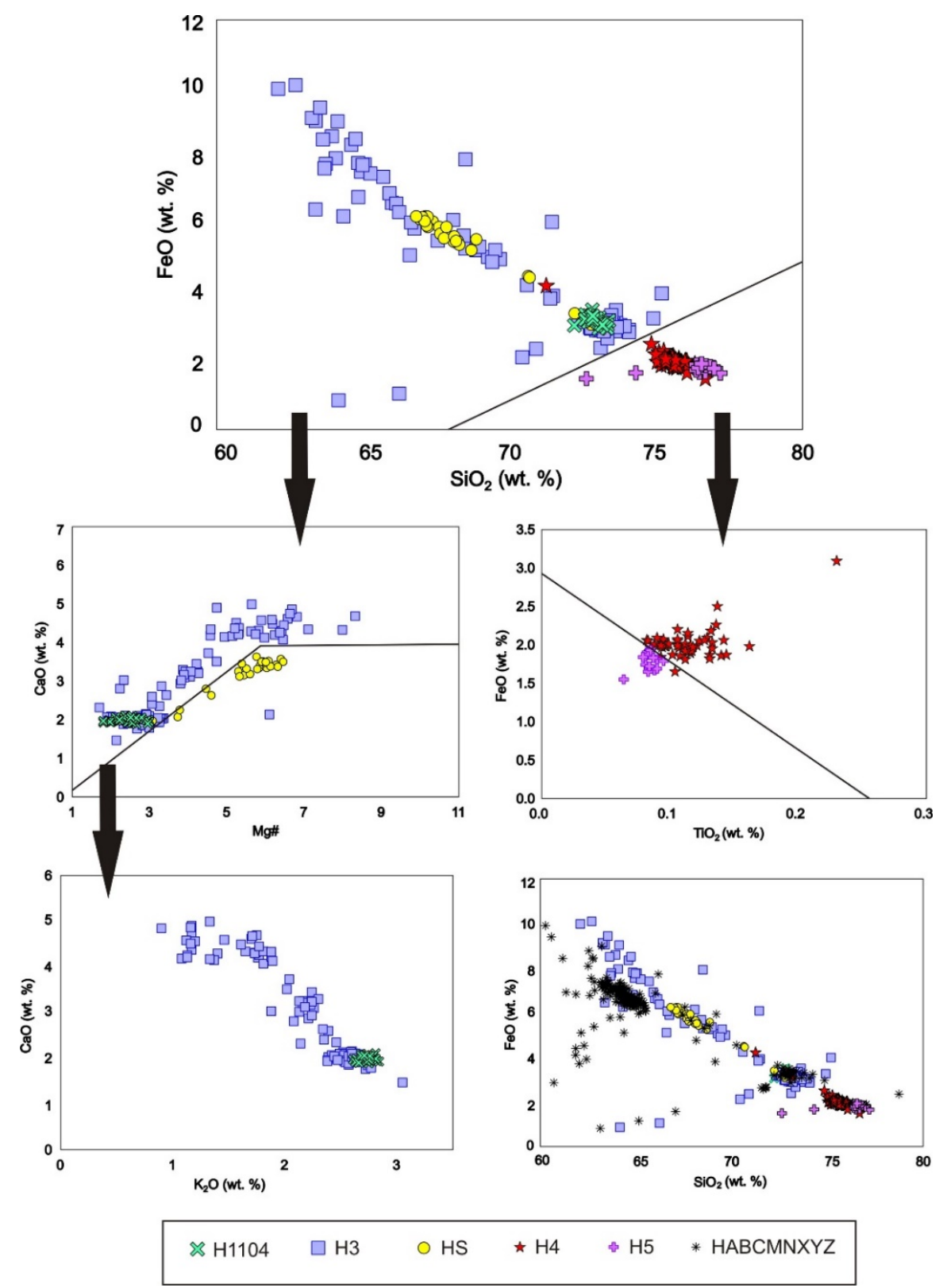

2 Figure 8: A basic methodology for identifying the main tephra layers sourced within the Hekla volcanic system (H1104, H3, HS, H4 and H5) using glass major element data which are all normalised. Plotting

$4 \mathrm{SiO}_{2}$ and $\mathrm{FeO}$ allows the Hekla tephra layers to be sub-divided into two groups: group $1 \mathrm{H} 4-\mathrm{H} 5$; group

$52 \mathrm{H} 1104-\mathrm{H} 3-\mathrm{HS}$. Separating the $\mathrm{H} 4$ and $\mathrm{H} 5$ layers is possible by plotting $\mathrm{TiO}_{2}$ and $\mathrm{FeO}$. Accurately 6 identifying the tephra layers in group 2 is slightly more difficult. HS can be distinguished using Mg\# 7 whereas $\mathrm{H} 3$ and $\mathrm{H} 1104$ show differences in $\mathrm{K}_{2} \mathrm{O}$ concentration. However, a small amount of overlap 8 still remains between the analyses of the two layers. An issue arises when the HA-HB-HC-HM-HN-HX9 HY-HZ tephra layers are included as the more silicic end members of glass from these tephras show consistent overlap with $\mathrm{H} 3$ and $\mathrm{H} 1104$. The major element compositions of the glass from HA-HB-HC$\mathrm{HM}-\mathrm{HN}-\mathrm{HX}-\mathrm{HY}-\mathrm{HZ}$ layers are very similar and do not allow the tephra layers to be discriminated. 


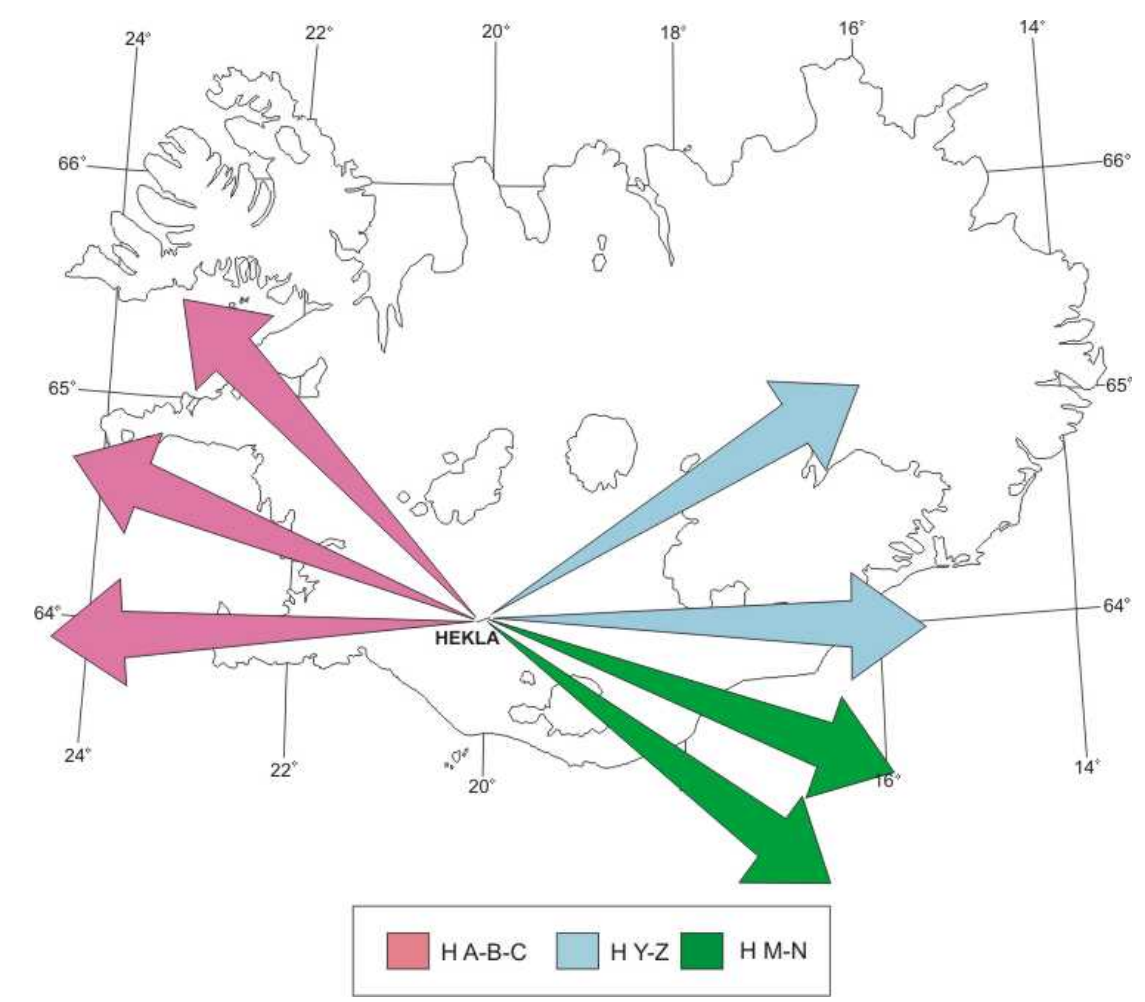

1

2 Figure 9: The assumed main axes of deposition for the seven less-widespread proximal Hekla 3 eruptions HA, HB, HC, HM, HN, HY and HZ. From Larsen and Eiríksson (2008).

4 

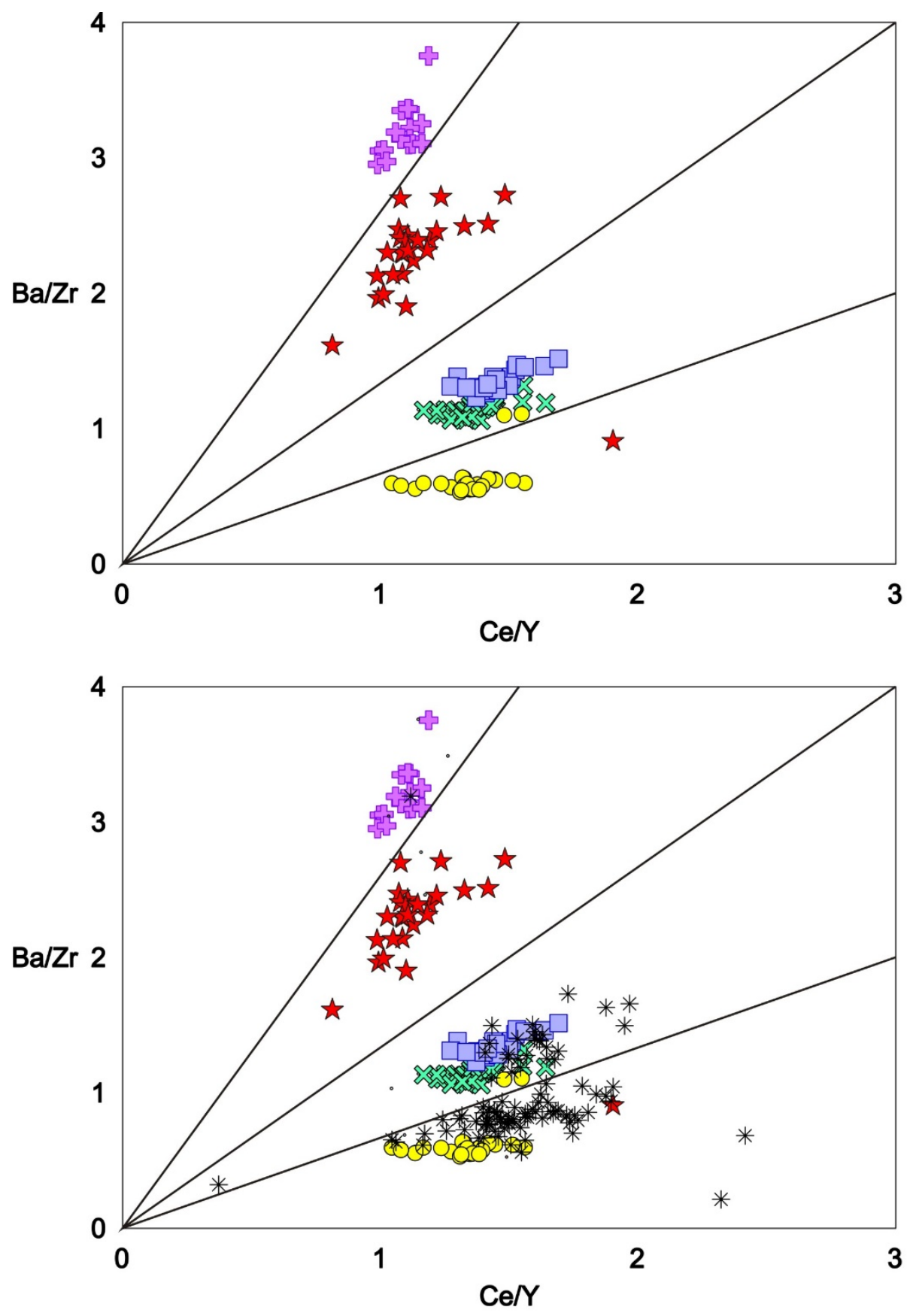

$\lesssim \mathrm{H} 1104 \quad \square \mathrm{H} 3 \quad \circ$ Hselsund $\star \mathrm{H} 4 \nRightarrow \mathrm{H} 5 \quad * \mathrm{HABCMNXYZ}$

2 Figure 10: Plotting the trace element ratios of $\mathrm{Ba} / \mathrm{Zr}$ and $\mathrm{Ce} / \mathrm{Y}$ allows for a relatively straightforward 3 discrimination of the major Hekla tephra layers ( $\mathrm{H} 1104, \mathrm{H} 3, \mathrm{HS}, \mathrm{H} 4$ and $\mathrm{H} 5$ ). Glasses from the $\mathrm{H} 4$ and $4 \quad \mathrm{H} 5$ tephra layers show relatively high $\mathrm{Ba} / \mathrm{Zr}$ values which eliminates the overlap shown in the major 5 element data. HS shows particularly low Ba/Zr values which easily separates the tephra from the $\mathrm{H} 3$ 6 and H1104 layers. A slight data overlap remains between the H3 and H1104 tephra layers but this 7 overlap is at its smallest when using the $B a / Z r$ ratios. Inclusion of the proximal tephra layers ( $H A, H B$, $8 \mathrm{HC}$ etc) causes overlap with the $\mathrm{H} 1104, \mathrm{H} 3$ and HS layers mirroring the major element data. 

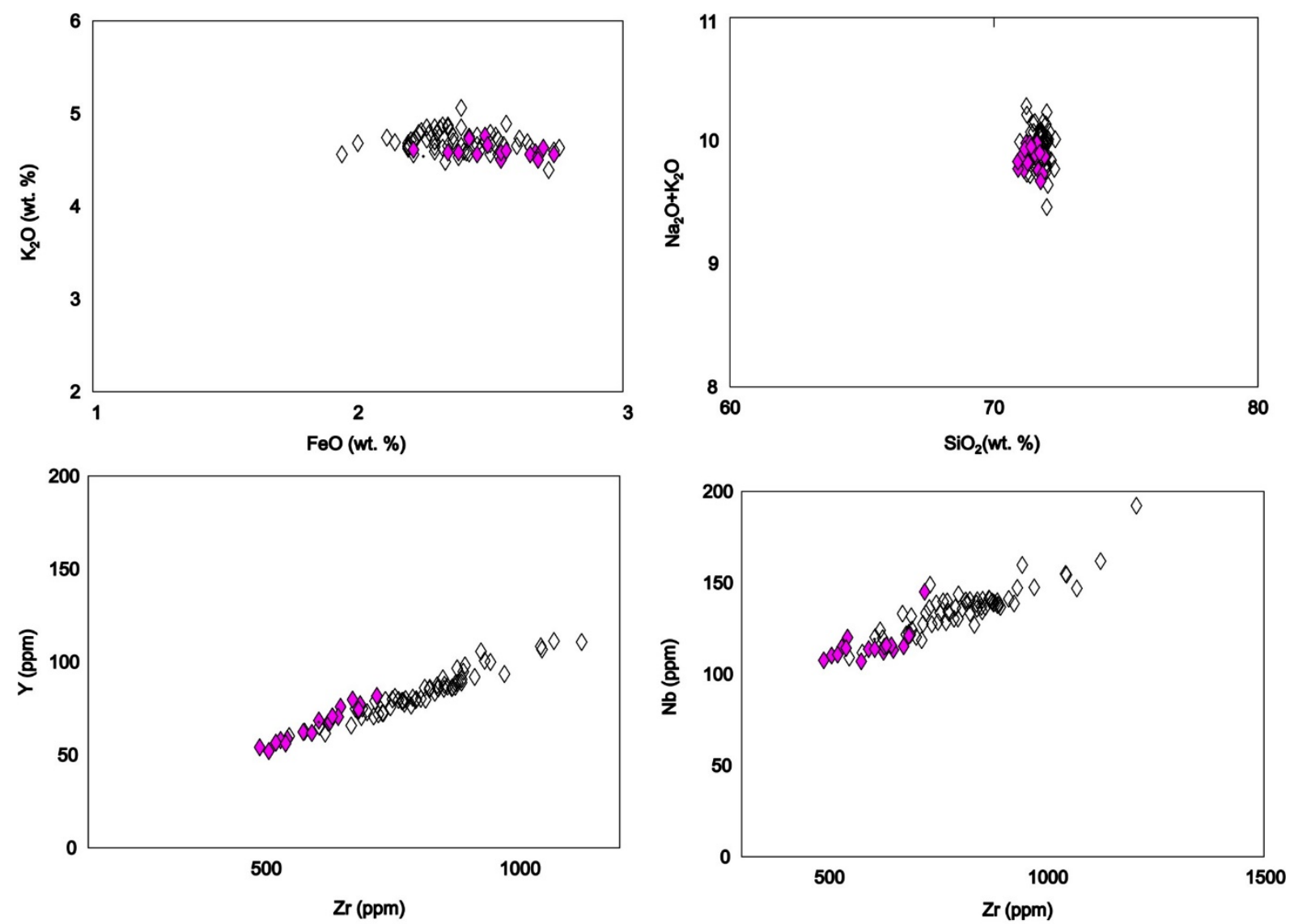

2 Figure 11: Bivariate plots of major and trace element data for glass shards of the Grákolla and 3 Landnám tephra layers of the Torfajökull volcanic system. All major analyses are normalised. The 4 tephra layers can be loosely separated using major elements (e.g. $\mathrm{K}_{2} \mathrm{O}$ and $\mathrm{FeO}$ ), but considerable 5 overlap remains in the data. Trace elements can be used to separate the layers with $\mathrm{Y}$ and $\mathrm{Zr}$ 6 particularly minimising, but not eliminating, the overlap. 

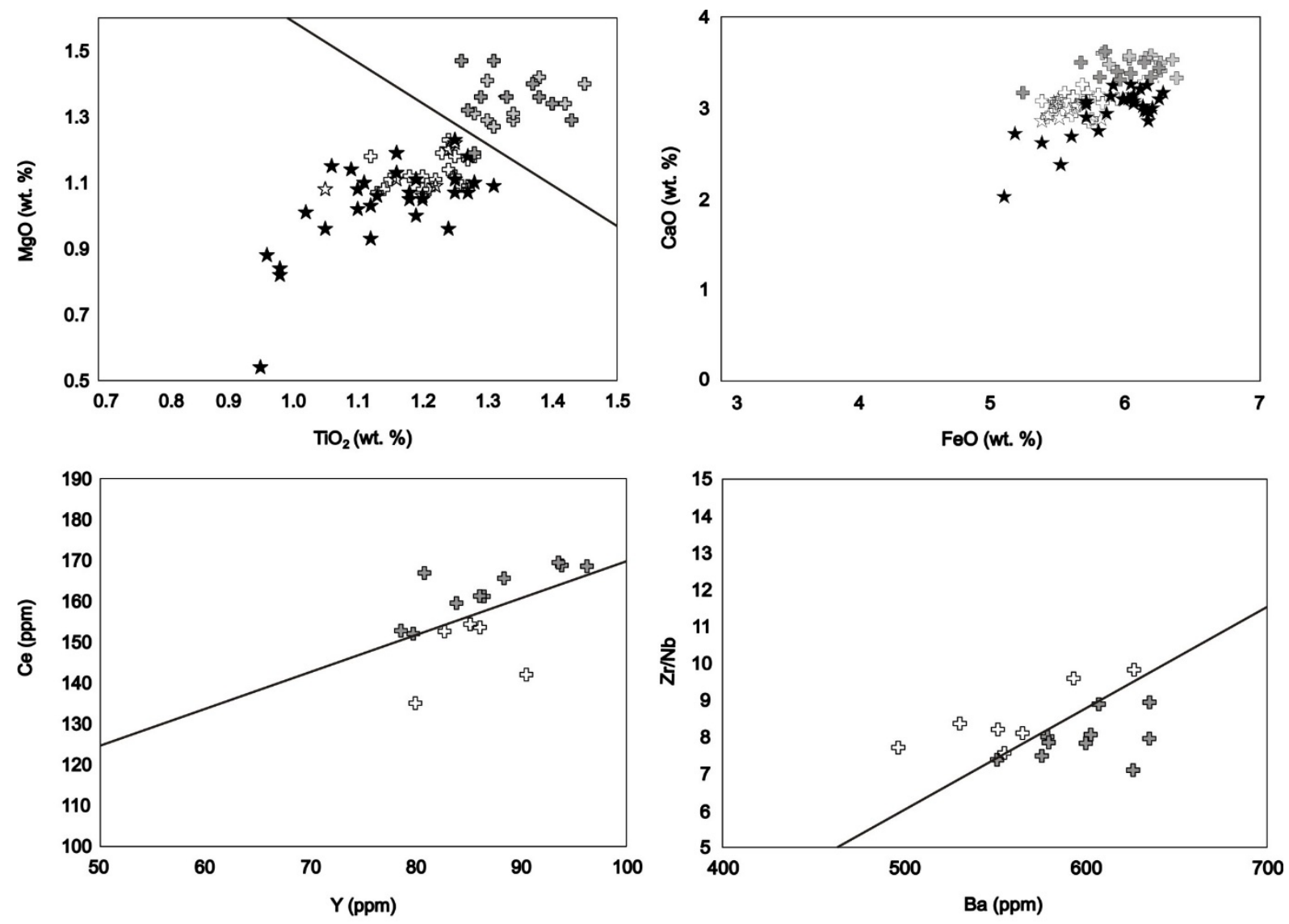

1 
1 Table 1: Volcanic systems and individual tephra layers analysed for this paper. The age of each 2 eruption is also recorded, both as age b2000 and as conventional ${ }^{14} \mathrm{C}$ radio carbon dates $+/-1$ standard 3 deviation (Thorarinsson, 1958, 1963, 1967; Larsen and Thorarinsson, 1977; Sigurdsson and Sparks, 4 1981; Dugmore et al. 1995; Grönvold et al. 1995; Boygle, 1998; Larsen et al. 2001; Selbekk and 5 Trønnes, 2007; Larsen and Eiríksson, 2008, Larsen et al. 2019).

\begin{tabular}{|l|l|l|l|}
\hline Source volcano & Tephra layer & Age (b2000) & ${ }^{14}$ C age BP \\
\hline Hekla & H1104 & 896 & \\
\hline Hekla & H3 & 3060 & $2879 \pm 34$ \\
\hline Hekla & HS & 3840 & $3515 \pm 55$ \\
\hline Hekla & H4 & 4250 & $3826 \pm 12$ \\
\hline Hekla & H5 & 7125 & $6185 \pm 90$ \\
\hline Hekla & HA & 2460 & $2390 \pm 25$ \\
& HB & 2800 & $2660 \pm 80$ \\
& HC & 2840 & \\
& HM & 2890 & \\
& HN & 2920 & \\
& HX & 2260 & \\
\hline Askja & HY & 2680 & \\
\hline Öræfajökull & HZ & 2760 & \\
\hline Katla & A1875 & 125 & \\
\hline Katla & Ö 1362 & 638 & \\
\hline Torfajökull / Vatnaöldur & Landnám & 1123 & \\
\hline Torfajökull / Vatnaöldur & Grákolla & c. 2200 & \\
\hline & UN & 3440 & \\
\hline
\end{tabular}


1 Table 2: Major element composition (wt. \%) of glass shards from Icelandic Holocene silicic tephra layers. Data 2 have been normalised (non-normalised totals [-n] are noted in the final column for comparison) and 1 standard 3 deviation is calculated. Raw data are available as supplementary information (see Table S13).

\begin{tabular}{|c|c|c|c|c|c|c|c|c|c|c|c|c|}
\hline Tephra & $\mathrm{SiO}_{2}$ & $\mathrm{TiO}_{2}$ & $\mathrm{Al}_{2} \mathrm{O}_{3}$ & $\mathrm{FeO}_{\mathrm{t}}$ & MnO & $\mathrm{MgO}$ & $\mathrm{CaO}$ & $\mathrm{Na}_{2} \mathrm{O}$ & $\mathrm{K}_{2} \mathrm{O}$ & $\mathrm{P}_{2} \mathrm{O}_{5}$ & Total & Total-n \\
\hline H1104-71 & 57.21 & 2.10 & 13.75 & 11.56 & 0.30 & 2.53 & 6.18 & 3.95 & 1.46 & 0.97 & 100.00 & 99.54 \\
\hline S.D. $(n=1)$ & N/A & $\mathrm{N} / \mathrm{A}$ & N/A & N/A & $\mathrm{N} / \mathrm{A}$ & N/A & $\mathrm{N} / \mathrm{A}$ & N/A & N/A & N/A & $\mathrm{N} / \mathrm{A}$ & N/A \\
\hline H1104-71 & 72.95 & 0.20 & 13.87 & 3.22 & 0.12 & 0.12 & 1.97 & 4.79 & 2.74 & 0.02 & 100.00 & 99.38 \\
\hline S.D. $(n=9)$ & 0.33 & 0.04 & 0.22 & 0.13 & 0.01 & 0.02 & 0.06 & 0.18 & 0.08 & 0.01 & 0.00 & 0.53 \\
\hline H1104-72 & 72.73 & 0.22 & 14.01 & 3.19 & 0.12 & 0.17 & 2.00 & 4.80 & 2.73 & 0.02 & 100.00 & 98.83 \\
\hline S.D. $(n=10)$ & 0.28 & 0.02 & 0.33 & 0.14 & 0.01 & 0.16 & 0.05 & 0.15 & 0.07 & 0.01 & 0.00 & 0.91 \\
\hline H1104-73 & 72.99 & 0.17 & 13.92 & 3.19 & 0.12 & 0.11 & 2.00 & 4.76 & 2.72 & 0.02 & 100.00 & 99.40 \\
\hline S.D. $(n=10)$ & 0.18 & 0.03 & 0.18 & 0.11 & 0.01 & 0.02 & 0.06 & 0.15 & 0.03 & 0.00 & 0.00 & 1.11 \\
\hline H1104 avg & 72.39 & 0.26 & 13.93 & 3.47 & 0.13 & 0.21 & 2.13 & 4.76 & 2.69 & 0.05 & 100.00 & 99.21 \\
\hline S.D. $(n=30)$ & 2.83 & 0.34 & 0.25 & 1.50 & 0.03 & 0.44 & 0.75 & 0.21 & 0.24 & 0.17 & 0.00 & 0.88 \\
\hline H3-79 & 70.63 & 0.28 & 14.54 & 4.29 & 0.32 & 0.23 & 2.63 & 4.68 & 2.34 & 0.05 & 100.00 & 98.54 \\
\hline S.D. $(n=11)$ & 1.98 & 0.08 & 0.45 & 1.06 & 0.03 & 0.08 & 0.48 & 0.19 & 0.16 & 0.03 & 0.00 & 1.87 \\
\hline H3-76 & 64.47 & 0.66 & 15.16 & 7.69 & 0.23 & 0.77 & 4.43 & 4.88 & 1.50 & 0.20 & 100.00 & 100.12 \\
\hline S.D. $(n=10)$ & 0.71 & 0.07 & 0.68 & 0.79 & 0.05 & 0.17 & 0.27 & 0.44 & 0.31 & 0.04 & 0.00 & 0.72 \\
\hline H3-76 & 72.96 & 0.18 & 14.17 & 2.98 & 0.10 & 0.12 & 2.09 & 4.85 & 2.51 & 0.02 & 100.00 & 99.13 \\
\hline S.D. $(n=20)$ & 0.88 & 0.03 & 0.75 & 0.34 & 0.02 & 0.03 & 0.32 & 0.45 & 0.23 & 0.01 & 0.00 & 0.77 \\
\hline H3-73 & 73.24 & 0.18 & 14.04 & 3.03 & 0.11 & 0.12 & 2.01 & 4.65 & 2.60 & 0.02 & 100.00 & 98.38 \\
\hline S.D. $(n=19)$ & 0.36 & 0.04 & 0.26 & 0.11 & 0.01 & 0.02 & 0.06 & 0.27 & 0.07 & 0.00 & 0.00 & 0.46 \\
\hline H3-70 & 64.93 & 0.71 & 14.96 & 7.70 & 0.22 & 0.77 & 4.42 & 4.54 & 1.52 & 0.22 & 100.00 & 99.35 \\
\hline S.D. $(n=20)$ & 1.64 & 0.19 & 0.78 & 1.42 & 0.04 & 0.29 & 0.24 & 1.21 & 0.29 & 0.08 & 0.00 & 0.77 \\
\hline H3-70 & 71.00 & 0.31 & 14.43 & 4.48 & 0.16 & 0.16 & 0.26 & 4.42 & 2.35 & 0.05 & 100.00 & 99.15 \\
\hline S.D. $(n=18)$ & 2.44 & 0.09 & 0.70 & 1.17 & 0.03 & 0.12 & 0.68 & 1.16 & 0.26 & 0.03 & 0.00 & 0.88 \\
\hline H3-66 & 73.19 & 0.16 & 13.94 & 3.09 & 0.11 & 0.14 & 2.01 & 4.78 & 2.55 & 0.02 & 100.00 & 98.65 \\
\hline S.D. $(n=21)$ & 0.33 & 0.05 & 0.27 & 0.12 & 0.01 & 0.04 & 0.07 & 0.20 & 0.08 & 0.01 & 0.00 & 0.59 \\
\hline H3 avg & 70.45 & 0.34 & 14.40 & 4.56 & 0.17 & 0.32 & 2.81 & 4.68 & 2.24 & 0.08 & 100.00 & 98.99 \\
\hline S.D. $(n=119)$ & 3.71 & 0.24 & 0.71 & 2.10 & 0.07 & 0.30 & 1.04 & 0.72 & 0.48 & 0.09 & 0.00 & 0.99 \\
\hline HS-77 & 68.83 & 0.42 & 14.87 & 5.19 & 0.16 & 0.46 & 3.15 & 4.69 & 2.13 & 0.09 & 100.00 & 98.86 \\
\hline S.D. $(n=10)$ & 2.01 & 0.11 & 0.30 & 1.09 & 0.03 & 0.16 & 0.57 & 0.12 & 0.21 & 0.03 & 0.00 & 0.69 \\
\hline HS-77 & 59.63 & 1.66 & 14.02 & 10.48 & 0.29 & 1.96 & 5.48 & 4.18 & 1.57 & 0.74 & 100.00 & 98.42 \\
\hline S.D. $(n=12)$ & 3.64 & 0.71 & 0.69 & 1.70 & 0.04 & 0.93 & 0.98 & 0.36 & 0.22 & 0.39 & 0.00 & 0.83 \\
\hline HS-78 & 67.75 & 0.44 & 14.96 & 5.81 & 0.18 & 0.57 & 3.30 & 4.79 & 2.07 & 0.13 & 100.00 & 99.14 \\
\hline S.D. $(n=11)$ & 1.45 & 0.08 & 0.31 & 0.68 & 0.02 & 0.12 & 0.31 & 0.08 & 0.10 & 0.03 & 0.00 & 0.31 \\
\hline HS-79 & 68.95 & 0.39 & 14.75 & 5.26 & 0.17 & 0.45 & 3.04 & 4.75 & 2.15 & 0.09 & 100.00 & 99.32 \\
\hline S.D. $(n=6)$ & 1.92 & 0.09 & 0.45 & 0.93 & 0.03 & 0.13 & 0.49 & 0.15 & 0.18 & 0.03 & 0.00 & 0.67 \\
\hline HS avg & 65.71 & 0.80 & 14.61 & 7.00 & 0.21 & 0.95 & 3.90 & 4.57 & 1.94 & 0.30 & 100.00 & 98.88 \\
\hline S.D. $(n=37)$ & 4.79 & 0.70 & 0.62 & 2.63 & 0.06 & 0.85 & 1.25 & 0.34 & 0.31 & 0.36 & 0.00 & 0.72 \\
\hline H4-101 & 60.02 & 1.33 & 14.72 & 10.02 & 0.27 & 1.97 & 5.56 & 4.21 & 1.51 & 0.40 & 100.00 & 98.80 \\
\hline S.D. $(n=9)$ & 5.30 & 0.81 & 0.17 & 2.07 & 0.02 & 1.70 & 1.87 & 0.71 & 0.41 & 0.21 & 0.00 & 0.58 \\
\hline H4-101 & 75.06 & 0.16 & 13.35 & 2.25 & 0.10 & 0.03 & 1.44 & 4.79 & 2.86 & 0.01 & 100.00 & 98.87 \\
\hline S.D. $(n=10)$ & 1.35 & 0.08 & 0.39 & 0.69 & 0.03 & 0.02 & 0.38 & 0.11 & 0.22 & 0.01 & 0.00 & 0.74 \\
\hline H4-96 & 75.55 & 0.13 & 13.24 & 2.01 & 0.09 & 0.02 & 1.33 & 4.74 & 2.91 & 0.00 & 100.00 & 98.67 \\
\hline S.D. $(n=10)$ & 0.26 & 0.01 & 0.22 & 0.13 & 0.01 & 0.00 & 0.03 & 0.08 & 0.05 & 0.00 & 0.00 & 0.57 \\
\hline H4-94 & 75.65 & 0.11 & 13.19 & 1.94 & 0.17 & 0.02 & 1.35 & 4.68 & 2.89 & 0.00 & 100.00 & 97.22 \\
\hline S.D. $(n=4)$ & 0.38 & 0.01 & 0.24 & 0.12 & 0.09 & 0.00 & 0.04 & 0.11 & 0.03 & 0.01 & 0.00 & 3.75 \\
\hline H4-92 & 75.46 & 0.11 & 13.19 & 2.09 & 0.24 & 0.02 & 1.35 & 4.62 & 2.92 & 0.00 & 100.00 & 98.16 \\
\hline S.D. $(n=9)$ & 0.33 & 0.02 & 0.19 & 0.19 & 0.00 & 0.00 & 0.06 & 0.18 & 0.04 & 0.01 & 0.00 & 0.60 \\
\hline H4-89 & 75.48 & 0.14 & 13.16 & 2.05 & 0.12 & 0.03 & 1.40 & 4.77 & 2.89 & 0.00 & 100.00 & 98.48 \\
\hline S.D. $(n=14)$ & 0.74 & 0.05 & 0.33 & 0.31 & 0.07 & 0.03 & 0.19 & 0.11 & 0.11 & 0.00 & 0.00 & 0.71 \\
\hline
\end{tabular}




\begin{tabular}{|c|c|c|c|c|c|c|c|c|c|c|c|c|}
\hline Tephra & $\mathrm{SiO}_{2}$ & $\mathrm{TiO}_{2}$ & $\mathrm{Al}_{2} \mathrm{O}_{3}$ & $\mathrm{FeO}_{\mathrm{t}}$ & $\mathrm{MnO}$ & MgO & $\mathrm{CaO}$ & $\mathrm{Na}_{2} \mathrm{O}$ & $\mathrm{K}_{2} \mathrm{O}$ & $\mathrm{P}_{2} \mathrm{O}_{5}$ & Total & Total-n \\
\hline H4-87 & 75.80 & 0.11 & 13.19 & 1.92 & 0.24 & 0.02 & 1.30 & 4.56 & 2.84 & 0.00 & 100.00 & 98.37 \\
\hline S.D. $(n=10)$ & 0.26 & 0.01 & 0.19 & 0.14 & 0.01 & 0.00 & 0.07 & 0.11 & 0.08 & 0.00 & 0.00 & 0.51 \\
\hline H4-86 & 75.83 & 0.10 & 13.08 & 1.92 & 0.23 & 0.02 & 1.30 & 4.58 & 2.95 & 0.00 & 100.00 & 98.36 \\
\hline S.D. $(n=10)$ & 0.49 & 0.01 & 0.18 & 0.18 & 0.01 & 0.00 & 0.09 & 0.14 & 0.07 & 0.00 & 0.00 & 0.89 \\
\hline H4-85 & 75.62 & 0.10 & 13.28 & 1.98 & 0.24 & 0.02 & 1.34 & 4.51 & 2.89 & 0.00 & 100.00 & 98.37 \\
\hline S.D. $(n=10)$ & 0.22 & 0.02 & 0.17 & 0.08 & 0.00 & 0.00 & 0.06 & 0.12 & 0.10 & 0.00 & 0.00 & 0.65 \\
\hline H4-84 & 75.32 & 0.10 & 13.34 & 2.03 & 0.24 & 0.02 & 1.38 & 4.65 & 2.92 & 0.00 & 100.00 & 98.68 \\
\hline S.D. $(n=7)$ & 0.25 & 0.01 & 0.10 & 0.11 & 0.00 & 0.00 & 0.04 & 0.18 & 0.05 & 0.01 & 0.00 & 0.66 \\
\hline H4 avg & 74.03 & 0.29 & 13.37 & 2.80 & 0.19 & 0.21 & 1.76 & 4.62 & 2.76 & 0.04 & 100.00 & 98.47 \\
\hline S.D. $(n=92)$ & 4.91 & 0.52 & 0.51 & 2.47 & 0.08 & 0.77 & 1.37 & 0.29 & 0.44 & 0.13 & 0.00 & 0.98 \\
\hline H5-4 & 47.22 & 3.74 & 13.83 & 14.59 & 0.22 & 5.99 & 10.89 & 2.60 & 0.54 & 0.39 & 10.00 & 98.85 \\
\hline S.D. $(n=6)$ & 0.42 & 0.86 & 1.43 & 1.05 & 0.02 & 0.82 & 0.28 & 0.13 & 0.11 & 0.10 & 0.00 & 0.38 \\
\hline H5-4 & 76.20 & 0.08 & 13.16 & 1.73 & 0.07 & 0.00 & 1.42 & 4.50 & 2.79 & 0.00 & 100.00 & 98.67 \\
\hline S.D. $(n=10)$ & 0.72 & 0.01 & 0.38 & 0.19 & 0.01 & 0.00 & 0.24 & 0.47 & 0.16 & 0.00 & 0.00 & 0.61 \\
\hline H5-5 & 76.70 & 0.09 & 12.89 & 1.78 & 0.07 & 0.00 & 1.30 & 4.30 & 2.83 & 0.00 & 100.00 & 95.22 \\
\hline S.D. $(n=3)$ & 0.29 & 0.01 & 0.20 & 0.09 & 0.01 & 0.00 & 0.06 & 0.14 & 0.07 & 0.01 & 0.00 & 1.92 \\
\hline H5 avg & 67.32 & 1.24 & 13.23 & 5.82 & 0.12 & 1.89 & 4.35 & 3.79 & 2.10 & 0.12 & 100.00 & 98.18 \\
\hline S.D. $(n=)$ & 14.03 & 1.79 & 0.84 & 6.14 & 0.07 & 2.89 & 4.57 & 0.86 & 1.09 & 0.19 & 0.00 & 1.55 \\
\hline HA-19 & 50.93 & 0.60 & 1.95 & 14.14 & 0.53 & 12.72 & 18.82 & 0.28 & 0.00 & 0.00 & 100.00 & 99.69 \\
\hline S.D. $(n=1)$ & N/A & N/A & N/A & N/A & N/A & N/A & N/A & N/A & N/A & N/A & N/A & N/A \\
\hline HA-19 & 65.11 & 0.84 & 15.37 & 6.54 & 0.17 & 1.21 & 4.31 & 4.47 & 1.72 & 0.27 & 100.00 & 98.89 \\
\hline S.D. $(n=9)$ & 0.38 & 0.07 & 0.22 & 0.23 & 0.01 & 0.05 & 0.15 & 0.09 & 0.03 & 0.02 & 0.00 & 0.45 \\
\hline HA avg & 63.69 & 0.81 & 14.03 & 7.30 & 0.21 & 2.36 & 5.76 & 4.05 & 1.55 & 0.24 & 100.00 & 98.97 \\
\hline S.D. $(n=10)$ & 4.50 & 0.10 & 4.25 & 2.41 & 0.11 & 3.64 & 4.59 & 1.33 & 0.54 & 0.09 & 0.00 & 0.49 \\
\hline HB-17 & 55.84 & 2.09 & 14.92 & 11.41 & 0.27 & 2.88 & 6.68 & 3.67 & 1.21 & 1.03 & 100.00 & 98.69 \\
\hline S.D. $(n=12)$ & 1.75 & 0.36 & 1.09 & 1.77 & 0.05 & 0.56 & 0.40 & 0.54 & 0.15 & 0.22 & 0.00 & 0.83 \\
\hline HB-17 & 71.04 & 0.30 & 14.32 & 4.20 & 0.15 & 0.24 & 2.58 & 4.71 & 2.39 & 0.06 & 100.00 & 98.59 \\
\hline S.D. $(n=5)$ & 3.32 & 0.16 & 0.68 & 1.61 & 0.05 & 0.17 & 0.89 & 0.09 & 0.30 & 0.05 & 0.00 & 0.45 \\
\hline HB-18 & 63.95 & 0.95 & 15.37 & 7.10 & 0.19 & 1.35 & 4.56 & 4.52 & 1.66 & 0.33 & 100.00 & 99.21 \\
\hline S.D. $(n=10)$ & 0.96 & 0.07 & 0.91 & 0.30 & 0.01 & 0.10 & 0.37 & 0.15 & 0.14 & 0.03 & 0.00 & 0.70 \\
\hline HB avg & 61.66 & 1.33 & 14.98 & 8.48 & 0.22 & 1.82 & 5.14 & 4.18 & 1.60 & 0.59 & 100.00 & 98.86 \\
\hline S.D. $(n=27)$ & 6.15 & 0.77 & 1.00 & 3.16 & 0.06 & 1.10 & 1.65 & 0.59 & 0.47 & 0.44 & 0.00 & 0.76 \\
\hline HC-13 & 55.47 & 2.63 & 13.39 & 12.87 & 0.31 & 2.95 & 6.24 & 3.28 & 1.44 & 1.42 & 100.00 & 98.56 \\
\hline S.D. $(n=5)$ & 0.66 & 0.10 & 0.32 & 0.45 & 0.02 & 0.11 & 0.29 & 0.32 & 0.03 & 0.04 & 0.00 & 0.49 \\
\hline HC-14 & 55.96 & 2.20 & 14.23 & 11.96 & 0.30 & 2.91 & 6.20 & 3.70 & 1.41 & 1.12 & 100.00 & 99.43 \\
\hline S.D. $(n=10)$ & 1.25 & 0.21 & 0.51 & 0.79 & 0.02 & 0.24 & 0.45 & 0.69 & 0.18 & 0.15 & 0.00 & 0.65 \\
\hline HC-14 & 64.10 & 0.89 & 15.49 & 6.93 & 0.19 & 1.26 & 4.54 & 4.66 & 1.65 & 0.31 & 100.00 & 98.81 \\
\hline S.D. $(n=10)$ & 0.65 & 0.07 & 0.50 & 0.36 & 0.02 & 0.12 & 0.26 & 0.15 & 0.12 & 0.03 & 0.00 & 0.56 \\
\hline HC-15 & 63.44 & 0.77 & 16.98 & 5.98 & 0.16 & 1.14 & 5.05 & 4.78 & 1.44 & 0.26 & 100.00 & 99.09 \\
\hline S.D. $(n=10)$ & 2.22 & 0.26 & 3.32 & 1.89 & 0.05 & 0.44 & 1.28 & 0.61 & 0.42 & 0.06 & 0.00 & 0.74 \\
\hline HC-16 & 65.20 & 0.76 & 16.33 & 5.34 & 0.15 & 0.97 & 4.70 & 4.64 & 1.68 & 0.23 & 100.00 & 99.21 \\
\hline S.D. $(n=10)$ & 4.91 & 0.18 & 2.98 & 1.53 & 0.05 & 0.39 & 1.69 & 0.59 & 0.82 & 0.07 & 0.00 & 0.77 \\
\hline HC avg & 61.43 & 1.32 & 15.50 & 8.14 & 0.21 & 1.72 & 5.25 & 4.32 & 1.53 & 0.58 & 100.00 & 99.07 \\
\hline S.D. $(n=45)$ & 4.79 & 0.77 & 2.39 & 3.23 & 0.07 & 0.91 & 1.22 & 0.75 & 0.44 & 0.47 & 0.00 & 0.70 \\
\hline HM-24 & 50.56 & 3.92 & 13.07 & 14.03 & 0.26 & 4.38 & 8.77 & 3.19 & 1.01 & 0.81 & 100.00 & 98.47 \\
\hline S.D. $(n=10)$ & 4.47 & 1.23 & 0.55 & 1.71 & 0.03 & 1.31 & 2.06 & 0.38 & 0.45 & 0.27 & 0.00 & 0.52 \\
\hline HM-24 & 63.19 & 0.95 & 15.79 & 7.17 & 0.20 & 1.21 & 4.81 & 4.80 & 1.55 & 0.31 & 100.00 & 99.43 \\
\hline S.D. $(n=10)$ & 0.82 & 0.09 & 1.13 & 1.20 & 0.05 & 0.16 & 0.54 & 0.29 & 0.27 & 0.03 & 0.00 & 0.61 \\
\hline HM-23 & 53.68 & 2.82 & 14.83 & 11.60 & 0.25 & 3.20 & 7.78 & 3.88 & 1.10 & 0.86 & 100.00 & 98.97 \\
\hline S.D. $(n=10)$ & 5.70 & 1.75 & 3.58 & 4.52 & 0.08 & 1.67 & 2.14 & 1.00 & 0.46 & 0.50 & 0.00 & 0.76 \\
\hline
\end{tabular}


Table 2: (continued)

\begin{tabular}{|c|c|c|c|c|c|c|c|c|c|c|c|c|}
\hline Tephra & $\mathrm{SiO}_{2}$ & $\mathrm{TiO}_{2}$ & $\mathrm{Al}_{2} \mathrm{O}_{3}$ & $\mathrm{FeO}_{\mathrm{t}}$ & $\mathrm{MnO}$ & MgO & $\mathrm{CaO}$ & $\mathrm{Na}_{2} \mathrm{O}$ & $\mathrm{K}_{2} \mathrm{O}$ & $\mathrm{P}_{2} \mathrm{O}_{5}$ & Total & Total-n \\
\hline HM-23 & 63.64 & 1.01 & 15.65 & 7.11 & 0.19 & 1.41 & 4.62 & 4.42 & 1.61 & 0.35 & 100.00 & 99.17 \\
\hline S.D. $(n=10)$ & 0.90 & 0.08 & 0.32 & 0.46 & 0.01 & 0.14 & 0.28 & 0.15 & 0.09 & 0.04 & 0.00 & 0.74 \\
\hline HM-22 & 48.12 & 3.46 & 12.39 & 14.70 & 0.02 & 7.36 & 10.26 & 2.56 & 0.50 & 0.38 & 100.00 & 98.30 \\
\hline S.D. $(n=10)$ & 1.46 & 1.29 & 4.06 & 3.57 & 0.07 & 4.33 & 3.12 & 0.93 & 0.22 & 0.18 & 0.00 & 0.80 \\
\hline HM-22 & 64.16 & 0.93 & 15.77 & 6.57 & 0.18 & 1.31 & 4.70 & 4.52 & 1.56 & 0.29 & 100.00 & 99.11 \\
\hline S.D. $(n=10)$ & 0.66 & 0.05 & 0.71 & 0.47 & 0.01 & 0.13 & 0.30 & 0.25 & 0.10 & 0.02 & 0.00 & 0.66 \\
\hline HM avg & 57.55 & 2.12 & 14.61 & 10.05 & 0.18 & 3.09 & 6.72 & 3.91 & 1.24 & 0.49 & 100.00 & 98.92 \\
\hline S.D. $(n=60)$ & 7.30 & 1.58 & 2.51 & 4.12 & 0.09 & 2.92 & 2.82 & 0.97 & 0.49 & 0.32 & 0.00 & 0.77 \\
\hline HN-21 & 56.07 & 2.21 & 14.20 & 11.81 & 0.30 & 2.85 & 6.39 & 3.66 & 1.41 & 1.10 & 100.00 & 98.48 \\
\hline S.D. $(n=10)$ & 0.27 & 0.10 & 0.45 & 0.53 & 0.02 & 0.18 & 0.14 & 0.47 & 0.08 & 0.04 & 0.00 & 0.35 \\
\hline HN-21 & 62.49 & 0.80 & 17.88 & 5.59 & 0.15 & 1.09 & 5.63 & 4.84 & 1.28 & 0.25 & 100.00 & 99.41 \\
\hline S.D. $(n=10)$ & 2.65 & 0.35 & 4.05 & 2.32 & 0.08 & 0.52 & 1.81 & 0.61 & 0.55 & 0.11 & 0.00 & 0.75 \\
\hline HN-20 & 64.20 & 0.94 & 15.55 & 6.86 & 0.18 & 1.35 & 4.51 & 4.50 & 1.62 & 0.29 & 100.00 & 99.32 \\
\hline S.D. $(n=10)$ & 0.36 & 0.03 & 0.15 & 0.26 & 0.01 & 0.05 & 0.14 & 0.13 & 0.06 & 0.02 & 0.00 & 0.47 \\
\hline HN-19 & 54.35 & 2.25 & 12.76 & 13.81 & 0.35 & 4.90 & 6.34 & 3.04 & 1.20 & 1.00 & 100.00 & 98.66 \\
\hline S.D. $(n=10)$ & 2.79 & 0.80 & 4.14 & 3.87 & 0.16 & 5.25 & 2.25 & 1.12 & 0.52 & 0.44 & 0.00 & 0.71 \\
\hline HN-19 & 65.10 & 0.89 & 15.40 & 6.35 & 0.18 & 1.25 & 4.28 & 4.53 & 1.74 & 0.29 & 100.00 & 98.75 \\
\hline S.D. $(n=10)$ & 1.17 & 0.08 & 0.48 & 0.60 & 0.02 & 0.15 & 0.50 & 0.13 & 0.37 & 0.03 & 0.00 & 0.50 \\
\hline $\mathrm{HN}$ avg & 60.44 & 1.42 & 15.16 & 8.88 & 0.23 & 2.29 & 5.45 & 4.11 & 1.45 & 0.59 & 100.00 & 98.92 \\
\hline S.D. $(n=50)$ & 4.76 & 0.77 & 3.03 & 3.86 & 0.11 & 2.70 & 1.55 & 0.89 & 0.42 & 0.43 & 0.00 & 0.67 \\
\hline HX-1 & 55.49 & 2.30 & 14.36 & 11.76 & 0.28 & 3.13 & 6.70 & 3.60 & 1.30 & 1.08 & 100.00 & 98.41 \\
\hline S.D. $(n=10)$ & 0.68 & 0.11 & 0.39 & 0.70 & 0.02 & 0.17 & 0.23 & 0.40 & 0.07 & 0.05 & 0.00 & 0.48 \\
\hline HX-1 & 70.39 & 0.42 & 14.48 & 4.43 & 0.13 & 0.45 & 2.55 & 4.48 & 2.58 & 0.10 & 100.00 & 99.29 \\
\hline S.D. $(n=10)$ & 3.98 & 0.32 & 0.92 & 1.91 & 0.06 & 0.53 & 1.25 & 0.32 & 0.87 & 0.12 & 0.00 & 0.30 \\
\hline HX-2 & 54.02 & 2.58 & 14.07 & 12.38 & 0.28 & 3.74 & 7.41 & 3.48 & 1.13 & 0.90 & 100.00 & 98.72 \\
\hline S.D. $(n=11)$ & 2.84 & 0.77 & 0.73 & 1.39 & 0.03 & 1.12 & 1.65 & 0.41 & 0.39 & 0.34 & 0.00 & 0.69 \\
\hline HX-2 & 71.72 & 0.26 & 14.51 & 3.50 & 0.12 & 0.23 & 2.40 & 4.69 & 2.51 & 0.05 & 100.00 & 99.06 \\
\hline S.D. $(n=10)$ & 4.02 & 0.26 & 1.80 & 1.75 & 0.05 & 0.46 & 1.10 & 0.81 & 0.61 & 0.09 & 0.00 & 0.44 \\
\hline HX-3 & 53.79 & 2.88 & 13.60 & 12.97 & 0.29 & 3.64 & 7.34 & 3.42 & 1.17 & 0.91 & 100.00 & 98.90 \\
\hline S.D. $(n=10)$ & 3.64 & 0.96 & 0.76 & 1.63 & 0.04 & 0.94 & 1.29 & 0.25 & 0.26 & 0.29 & 0.00 & 0.56 \\
\hline HX-3 & 69.26 & 0.40 & 15.31 & 4.02 & 0.12 & 0.50 & 3.12 & 4.98 & 2.17 & 0.12 & 100.00 & 99.29 \\
\hline S.D. $(n=10)$ & 5.06 & 0.40 & 2.59 & 2.36 & 0.06 & 0.68 & 1.55 & 1.07 & 0.78 & 0.15 & 0.00 & 1.12 \\
\hline HX-3 & 63.19 & 0.99 & 15.38 & 7.38 & 0.38 & 1.50 & 4.80 & 4.44 & 1.56 & 0.38 & 100.00 & 99.50 \\
\hline S.D. $(n=10)$ & 0.89 & 0.15 & 0.55 & 0.89 & 0.03 & 0.31 & 0.32 & 0.25 & 0.13 & 0.10 & 0.00 & 0.87 \\
\hline HX avg & 62.43 & 1.42 & 14.52 & 8.12 & 0.23 & 1.91 & 4.94 & 4.15 & 1.77 & 0.51 & 100.00 & 99.02 \\
\hline S.D. $(n=71)$ & 8.20 & 1.18 & 1.40 & 4.24 & 0.10 & 1.61 & 2.40 & 0.81 & 0.78 & 0.45 & 0.00 & 0.75 \\
\hline HY-5 & 52.71 & 2.91 & 14.26 & 12.69 & 0.46 & 3.49 & 7.82 & 3.50 & 1.08 & 1.07 & 100.00 & 98.71 \\
\hline S.D. $(n=11)$ & 3.35 & 1.27 & 3.54 & 3.75 & 0.11 & 1.38 & 1.34 & 0.77 & 0.36 & 0.54 & 0.00 & 0.74 \\
\hline HY-5 & 64.58 & 0.85 & 15.44 & 6.55 & 0.35 & 1.27 & 4.58 & 4.49 & 1.61 & 0.30 & 100.00 & 99.28 \\
\hline S.D. $(n=10)$ & 1.97 & 0.25 & 0.60 & 1.15 & 0.03 & 0.39 & 0.57 & 0.19 & 0.20 & 0.14 & 0.00 & 0.58 \\
\hline HY-6 & 55.26 & 2.18 & 14.63 & 11.54 & 0.45 & 3.37 & 6.79 & 3.55 & 1.21 & 1.01 & 100.00 & 99.11 \\
\hline S.D. $(n=11)$ & 4.24 & 0.49 & 0.92 & 2.05 & 0.05 & 1.51 & 1.56 & 0.69 & 0.30 & 0.39 & 0.00 & 0.60 \\
\hline HY-6 & 68.63 & 0.55 & 14.76 & 4.66 & 0.30 & 0.78 & 3.16 & 4.73 & 2.26 & 0.17 & 100.00 & 99.26 \\
\hline S.D. $(n=10)$ & 4.63 & 0.39 & 0.80 & 2.10 & 0.05 & 0.65 & 1.52 & 0.39 & 0.82 & 0.15 & 0.00 & 0.65 \\
\hline HY-7 & 63.80 & 0.91 & 15.81 & 6.49 & 0.34 & 1.40 & 4.87 & 4.49 & 1.57 & 0.32 & 100.00 & 99.27 \\
\hline S.D. $(n=11)$ & 1.71 & 0.19 & 1.61 & 1.30 & 0.06 & 0.50 & 0.63 & 0.23 & 0.21 & 0.12 & 0.00 & 0.60 \\
\hline HY-7 & 55.02 & 2.22 & 14.46 & 11.80 & 0.47 & 3.22 & 6.65 & 3.70 & 1.27 & 1.18 & 100.00 & 99.20 \\
\hline S.D. $(n=10)$ & 0.93 & 0.21 & 0.63 & 0.89 & 0.02 & 0.20 & 0.30 & 0.45 & 0.10 & 0.11 & 0.00 & 0.79 \\
\hline
\end{tabular}


Table 2: (continued)

\begin{tabular}{|c|c|c|c|c|c|c|c|c|c|c|c|c|}
\hline Tephra & $\mathrm{SiO}_{2}$ & $\mathrm{TiO}_{2}$ & $\mathrm{Al}_{2} \mathrm{O}_{3}$ & $\mathrm{FeO}_{\mathrm{t}}$ & MnO & MgO & $\mathrm{CaO}$ & $\mathrm{Na}_{2} \mathrm{O}$ & $\mathrm{K}_{2} \mathrm{O}$ & $\mathrm{P}_{2} \mathrm{O}_{5}$ & Total & Total-n \\
\hline HY avg & 59.87 & 1.62 & 14.90 & 9.02 & 0.40 & 2.28 & 5.69 & 4.07 & 1.49 & 0.68 & 100.00 & 99.13 \\
\hline S.D. $(n=63)$ & 6.66 & 1.06 & 1.76 & 3.76 & 0.09 & 1.44 & 1.92 & 0.70 & 0.55 & 0.51 & 0.00 & 0.67 \\
\hline HZ-11 & 54.90 & 2.31 & 14.24 & 12.04 & 0.29 & 3.21 & 7.01 & 3.66 & 1.21 & 1.13 & 100.00 & 99.04 \\
\hline S.D. $(n=10)$ & 0.56 & 0.12 & 0.47 & 0.46 & 0.02 & 0.11 & 0.20 & 0.22 & 0.11 & 0.10 & 0.00 & 0.66 \\
\hline HZ-10 & 54.45 & 2.32 & 14.29 & 12.00 & 0.47 & 3.37 & 6.86 & 3.73 & 1.22 & 1.29 & 100.00 & 99.30 \\
\hline S.D. $(n=10)$ & 0.78 & 0.15 & 0.51 & 0.77 & 0.02 & 0.21 & 0.24 & 0.44 & 0.11 & 0.08 & 0.00 & 0.71 \\
\hline $\mathrm{HZ}-10$ & 70.64 & 0.30 & 14.69 & 3.86 & 0.28 & 0.33 & 2.54 & 4.80 & 2.48 & 0.07 & 100.00 & 99.29 \\
\hline S.D. $(n=10)$ & 4.45 & 0.28 & 2.20 & 2.09 & 0.07 & 0.48 & 1.23 & 1.09 & 0.79 & 0.11 & 0.00 & 1.18 \\
\hline HZ-9 & 53.09 & 2.45 & 14.20 & 12.88 & 0.49 & 3.64 & 7.15 & 3.56 & 1.17 & 1.38 & 100.00 & 98.98 \\
\hline S.D. $(n=10)$ & 0.36 & 0.08 & 0.50 & 0.45 & 0.01 & 0.06 & 0.10 & 0.23 & 0.08 & 0.04 & 0.00 & 0.87 \\
\hline HZ-9 & 69.20 & 0.48 & 14.78 & 4.62 & 0.30 & 0.65 & 2.95 & 4.47 & 2.39 & 0.14 & 100.00 & 99.12 \\
\hline S.D. $(n=10)$ & 3.80 & 0.32 & 0.65 & 1.64 & 0.04 & 0.59 & 1.39 & 0.25 & 0.91 & 0.13 & 0.00 & 0.41 \\
\hline $\mathrm{HZ}$ avg & 60.31 & 1.59 & 14.43 & 9.15 & 0.37 & 2.27 & 5.34 & 4.04 & 1.68 & 0.82 & 100.00 & 99.14 \\
\hline S.D. $(n=50)$ & 8.25 & 1.00 & 1.08 & 4.19 & 0.10 & 1.49 & 2.26 & 0.73 & 0.80 & 0.59 & 0.00 & 0.79 \\
\hline Landnám-15 & 71.93 & 0.26 & 14.39 & 2.26 & 0.08 & 0.23 & 0.89 & 5.20 & 4.73 & 0.03 & 100.00 & 98.47 \\
\hline S.D. $(n=10)$ & 0.24 & 0.04 & 0.20 & 0.16 & 0.01 & 0.03 & 0.05 & 0.14 & 0.09 & 0.01 & 0.00 & 0.63 \\
\hline Landnám-14 & 71.86 & 0.25 & 14.49 & 2.26 & 0.08 & 0.24 & 0.86 & 5.25 & 4.67 & 0.03 & 100.00 & 98.63 \\
\hline S.D. $(n=10)$ & 0.22 & 0.04 & 0.22 & 0.15 & 0.01 & 0.02 & 0.05 & 0.13 & 0.10 & 0.00 & 0.00 & 0.62 \\
\hline Landnám-11 & 71.78 & 0.26 & 14.35 & 2.36 & 0.07 & 0.24 & 0.87 & 5.28 & 4.75 & 0.03 & 100.00 & 98.39 \\
\hline S.D. $(n=10)$ & 0.25 & 0.02 & 0.20 & 0.15 & 0.01 & 0.02 & 0.04 & 0.12 & 0.13 & 0.01 & 0.00 & 0.62 \\
\hline Landnám-11 & 46.65 & 2.61 & 15.79 & 13.03 & 0.21 & 7.45 & 10.95 & 2.65 & 0.41 & 0.24 & 100.00 & 97.60 \\
\hline S.D. $(n=7)$ & 0.40 & 0.10 & 0.25 & 0.27 & 0.01 & 0.09 & 0.08 & 0.06 & 0.03 & 0.01 & 0.00 & 0.50 \\
\hline Landnám-10 & 71.77 & 0.27 & 14.47 & 2.38 & 0.08 & 0.24 & 0.89 & 5.15 & 4.73 & 0.03 & 100.00 & 98.58 \\
\hline S.D. $(n=10)$ & 0.25 & 0.03 & 0.23 & 0.09 & 0.01 & 0.02 & 0.03 & 0.12 & 0.09 & 0.01 & 0.00 & 0.52 \\
\hline Landnám-8 & 71.78 & 0.25 & 14.41 & 2.39 & 0.08 & 0.22 & 0.91 & 5.26 & 4.67 & 0.03 & 100.00 & 98.62 \\
\hline S.D. $(n=10)$ & 0.20 & 0.03 & 0.09 & 0.17 & 0.01 & 0.02 & 0.06 & 0.09 & 0.11 & 0.01 & 0.00 & 0.50 \\
\hline Landnám avg & 68.88 & 0.53 & 14.58 & 3.58 & 0.09 & 1.08 & 2.06 & 4.93 & 4.21 & 0.06 & 100.00 & 98.41 \\
\hline S.D. $(n=57)$ & 8.15 & 0.76 & 0.49 & 3.47 & 0.04 & 2.34 & 3.26 & 0.84 & 1.40 & 0.07 & 0.00 & 0.64 \\
\hline Grákolla-16 & 71.38 & 0.25 & 14.59 & 2.56 & 0.07 & 0.25 & 0.93 & 5.31 & 4.62 & 0.03 & 100.00 & 99.76 \\
\hline S.D. $(n=9)$ & 0.22 & 0.04 & 0.11 & 0.12 & 0.00 & 0.03 & 0.05 & 0.15 & 0.12 & 0.02 & 0.00 & 0.40 \\
\hline Grákolla-16 & 49.25 & 3.01 & 13.39 & 13.71 & 0.24 & 5.94 & 10.94 & 2.76 & 0.43 & 0.36 & 100.00 & 99.14 \\
\hline S.D. $(n=10)$ & 1.36 & 1.43 & 0.49 & 1.06 & 0.02 & 0.87 & 0.86 & 0.39 & 0.29 & 0.26 & 0.00 & 0.66 \\
\hline Grákolla-97 & 71.41 & 0.24 & 14.58 & 2.65 & 0.08 & 0.25 & 0.93 & 5.24 & 4.61 & 0.03 & 100.00 & 99.54 \\
\hline S.D. $(n=10)$ & 0.34 & 0.03 & 0.27 & 0.24 & 0.01 & 0.04 & 0.08 & 0.07 & 0.09 & 0.01 & 0.00 & 0.59 \\
\hline Grákolla-97 & 49.58 & 2.90 & 13.28 & 13.53 & 0.23 & 6.17 & 10.88 & 2.67 & 0.43 & 0.34 & 100.00 & 98.88 \\
\hline S.D. $(n=9)$ & 1.09 & 1.43 & 0.46 & 0.99 & 0.01 & 0.92 & 0.96 & 0.43 & 0.29 & 0.25 & 0.00 & 0.65 \\
\hline Grákolla-101 & 71.50 & 0.25 & 14.58 & 2.51 & 0.08 & 0.23 & 0.93 & 5.31 & 4.58 & 0.02 & 100.00 & 99.45 \\
\hline S.D. $(n=10)$ & 0.29 & 0.06 & 0.20 & 0.18 & 0.01 & 0.02 & 0.06 & 0.11 & 0.05 & 0.01 & 0.00 & 0.46 \\
\hline Grákolla avg & 62.71 & 1.32 & 14.09 & 6.95 & 0.14 & 2.54 & 4.88 & 4.27 & 2.95 & 0.15 & 100.00 & 99.36 \\
\hline S.D. $(n=48)$ & 10.92 & 1.59 & 0.70 & 5.50 & 0.08 & 2.92 & 4.96 & 1.30 & 2.07 & 0.22 & 0.00 & 0.62 \\
\hline A1875-D4 & 50.60 & 1.92 & 13.90 & 12.82 & 0.23 & 6.46 & 10.92 & 2.62 & 0.35 & 0.19 & 100.00 & 98.77 \\
\hline S.D. $(n=2)$ & 0.03 & 0.17 & 0.12 & 0.88 & 0.01 & 0.58 & 0.60 & 0.20 & 0.04 & 0.03 & 0.00 & 0.29 \\
\hline A1875-D4 & 71.97 & 0.93 & 12.96 & 4.01 & 0.11 & 0.77 & 2.82 & 3.90 & 2.35 & 0.18 & 100.00 & 100.30 \\
\hline S.D. $(n=8)$ & 1.03 & 0.07 & 0.25 & 0.54 & 0.01 & 0.16 & 0.32 & 0.19 & 0.14 & 0.03 & 0.00 & 0.53 \\
\hline A1875-D3 & 73.00 & 0.89 & 12.51 & 3.59 & 0.11 & 0.73 & 2.70 & 3.86 & 2.45 & 0.16 & 100.00 & 100.15 \\
\hline S.D. $(n=10)$ & 0.36 & 0.02 & 0.25 & 0.16 & 0.01 & 0.03 & 0.11 & 0.11 & 0.08 & 0.01 & 0.00 & 0.38 \\
\hline A1875-D2 & 52.61 & 2.30 & 13.14 & 14.41 & 0.22 & 4.68 & 8.90 & 2.84 & 0.68 & 0.24 & 100.00 & 99.24 \\
\hline S.D. $(n=2)$ & 0.31 & 0.00 & 0.04 & 0.13 & 0.01 & 0.12 & 0.16 & 0.03 & 0.02 & 0.01 & 0.00 & 0.05 \\
\hline A1875-D2 & 73.00 & 0.86 & 12.62 & 3.65 & 0.11 & 0.70 & 2.50 & 3.99 & 2.40 & 0.16 & 100.00 & 100.12 \\
\hline S.D. $(n=8)$ & 0.78 & 0.05 & 0.22 & 0.38 & 0.01 & 0.08 & 0.22 & 0.07 & 0.08 & 0.02 & 0.00 & 0.41 \\
\hline
\end{tabular}




\begin{tabular}{|c|c|c|c|c|c|c|c|c|c|c|c|c|}
\hline Tephra & $\mathrm{SiO}_{2}$ & $\mathrm{TiO}_{2}$ & $\mathrm{Al}_{2} \mathrm{O}_{3}$ & $\mathrm{FeO}_{\mathrm{t}}$ & MnO & MgO & $\mathrm{CaO}$ & $\mathrm{Na}_{2} \mathrm{O}$ & $\mathrm{K}_{2} \mathrm{O}$ & $\mathrm{P}_{2} \mathrm{O}_{5}$ & Total & Total-n \\
\hline A1875-D1 & 72.84 & 0.88 & 12.69 & 3.68 & 0.11 & 0.73 & 2.64 & 3.83 & 2.43 & 0.16 & 100.00 & 99.81 \\
\hline S.D. $(n=10)$ & 1.05 & 0.07 & 0.22 & 0.45 & 0.01 & 0.11 & 0.35 & 0.19 & 0.09 & 0.03 & 0.00 & 0.98 \\
\hline A1875-C59 & 51.12 & 2.16 & 13.27 & 14.15 & 0.24 & 5.57 & 10.07 & 2.74 & 0.48 & 0.21 & 100.00 & 98.78 \\
\hline S.D. $(n=10)$ & 0.98 & 0.14 & 0.37 & 0.56 & 0.01 & 0.62 & 0.79 & 0.15 & 0.15 & 0.02 & 0.00 & 0.50 \\
\hline A1875-C59 & 73.61 & 0.69 & 12.57 & 3.22 & 0.10 & 0.58 & 2.22 & 3.95 & 2.92 & 0.16 & 100.00 & 99.15 \\
\hline S.D. $(n=12)$ & 0.73 & 0.30 & 0.35 & 0.82 & 0.02 & 0.26 & 0.69 & 0.09 & 1.10 & 0.01 & 0.00 & 0.45 \\
\hline A1875-C57 & 51.03 & 2.07 & 13.32 & 13.83 & 0.24 & 5.84 & 10.38 & 2.71 & 0.38 & 0.21 & 100.00 & 98.42 \\
\hline S.D. $(n=10)$ & 0.69 & 0.16 & 0.33 & 0.57 & 0.01 & 0.50 & 0.68 & 0.10 & 0.11 & 0.02 & 0.00 & 0.39 \\
\hline A1875-C57 & 73.83 & 0.79 & 12.31 & 3.45 & 0.10 & 0.65 & 2.36 & 3.91 & 2.44 & 0.15 & 100.00 & 99.44 \\
\hline S.D. $(n=10)$ & 0.76 & 0.05 & 0.28 & 0.23 & 0.01 & 0.08 & 0.24 & 0.08 & 0.07 & 0.03 & 0.00 & 0.61 \\
\hline A1875-C55 & 51.09 & 2.08 & 13.26 & 13.92 & 0.24 & 5.79 & 10.30 & 2.72 & 0.40 & 0.21 & 100.00 & 98.82 \\
\hline S.D. $(n=10)$ & 0.64 & 0.14 & 0.31 & 0.83 & 0.01 & 0.50 & 0.58 & 0.14 & 0.09 & 0.02 & 0.00 & 0.56 \\
\hline A1875-C55 & 74.28 & 0.77 & 12.29 & 3.28 & 0.10 & 0.61 & 2.22 & 3.83 & 2.47 & 0.14 & 100.00 & 98.53 \\
\hline S.D. $(n=10)$ & 0.36 & 0.04 & 0.21 & 0.16 & 0.01 & 0.04 & 0.12 & 0.08 & 0.08 & 0.01 & 0.00 & 0.71 \\
\hline A1875-C54 & 51.50 & 2.17 & 13.14 & 14.30 & 0.24 & 5.42 & 9.81 & 2.74 & 0.47 & 0.22 & 100.00 & 98.74 \\
\hline S.D. $(n=9)$ & 0.77 & 0.10 & 0.33 & 0.40 & 0.01 & 0.40 & 0.47 & 0.10 & 0.12 & 0.02 & 0.00 & 0.67 \\
\hline A1875-C54 & 74.42 & 0.75 & 12.28 & 3.20 & 0.10 & 0.58 & 2.22 & 3.84 & 2.48 & 0.12 & 100.00 & 99.19 \\
\hline S.D. $(n=9)$ & 0.65 & 0.05 & 0.32 & 0.25 & 0.01 & 0.06 & 0.17 & 0.05 & 0.09 & 0.02 & 0.00 & 0.89 \\
\hline A1875-B61 & 73.99 & 0.80 & 12.50 & 3.21 & 0.10 & 0.60 & 2.36 & 3.83 & 2.47 & 0.14 & 100.00 & 100.09 \\
\hline S.D. $(n=10)$ & 0.65 & 0.04 & 0.53 & 0.25 & 0.01 & 0.05 & 0.35 & 0.19 & 0.12 & 0.01 & 0.00 & 0.35 \\
\hline A1875 avg & 66.11 & 1.24 & 12.77 & 6.94 & 0.15 & 2.31 & 4.98 & 3.50 & 1.82 & 0.17 & 100.00 & 99.31 \\
\hline S.D. $(n=130)$ & 10.56 & 0.63 & 0.50 & 5.01 & 0.06 & 2.39 & 3.67 & 0.56 & 1.04 & 0.04 & 0.00 & 0.85 \\
\hline SILK UN & 65.86 & 1.34 & 13.98 & 6.14 & 0.20 & 1.33 & 3.51 & 4.65 & 2.62 & 0.37 & 100.00 & 99.06 \\
\hline S.D. $(n=10)$ & 0.16 & 0.06 & 0.23 & 0.19 & 0.01 & 0.06 & 0.08 & 0.17 & 0.08 & 0.01 & 0.00 & 0.62 \\
\hline SILM LN & 66.80 & 1.22 & 14.03 & 5.71 & 0.20 & 1.13 & 3.12 & 4.74 & 2.74 & 0.31 & 100.00 & 99.10 \\
\hline S.D. $(n=10)$ & 0.35 & 0.05 & 0.21 & 0.20 & 0.01 & 0.06 & 0.11 & 0.10 & 0.07 & 0.01 & 0.00 & 0.84 \\
\hline Ö1362-20 & 73.22 & 0.24 & 13.31 & 3.31 & 0.10 & 0.000 & 0.98 & 5.43 & 3.38 & 0.00 & 100.00 & 99.19 \\
\hline S.D. $(n=9)$ & 0.25 & 0.03 & 0.15 & 0.16 & 0.01 & 0.00 & 0.04 & 0.04 & 0.10 & 0.01 & 0.00 & 1.05 \\
\hline Ö1362-33 & 73.20 & 0.23 & 13.19 & 3.34 & 0.10 & 0.00 & 1.00 & 5.37 & 3.54 & 0.00 & 100.00 & 98.62 \\
\hline S.D. $(n=10)$ & 0.35 & 0.01 & 0.20 & 0.15 & 0.01 & 0.00 & 0.05 & 0.10 & 0.12 & 0.01 & 100.00 & 0.73 \\
\hline Ö1362-48 & 73.28 & 0.24 & 13.31 & 3.31 & 0.10 & 0.00 & 1.01 & 5.24 & 3.47 & 0.00 & 100.00 & 98.32 \\
\hline S.D. $(n=10)$ & 0.30 & 0.02 & 0.16 & 0.14 & 0.01 & 0.00 & 0.03 & 0.20 & 0.05 & 0.00 & 0.00 & 0.61 \\
\hline Ö1362-59 & 73.17 & 0.24 & 13.22 & 3.26 & 0.11 & 0.01 & 1.02 & 5.51 & 3.44 & 0.00 & 100.00 & 98.77 \\
\hline S.D. $(n=10)$ & 0.25 & 0.03 & 0.19 & 0.09 & 0.01 & 0.02 & 0.05 & 0.05 & 0.11 & 0.07 & 0.00 & 0.77 \\
\hline Ö1362-65 & 73.27 & 0.24 & 13.25 & 3.28 & 0.11 & 0.00 & 1.03 & 5.40 & 3.40 & 0.00 & 100.00 & 98.64 \\
\hline S.D. $(n=10)$ & 0.22 & 0.04 & 0.16 & 0.15 & 0.01 & 0.00 & 0.05 & 0.13 & 0.08 & 0.01 & 0.00 & 0.64 \\
\hline Ö1362 avg & 73.23 & 0.23 & 13.25 & 3.30 & 0.11 & 0.00 & 1.01 & 5.39 & 3.45 & 0.00 & 100.00 & 98.70 \\
\hline S.D. $(n=49)$ & 0.27 & 0.04 & 0.17 & 0.14 & 0.01 & 0.01 & 0.04 & 0.15 & 0.10 & 0.00 & 0.00 & 0.78 \\
\hline
\end{tabular}

2 
Table 3: Trace element composition (ppm) of glass shards from Icelandic Holocene silicic tephra layers. Raw data are available as supplementary information (see S13).

\begin{tabular}{|c|c|c|c|c|c|c|c|c|c|c|c|c|c|c|c|c|c|c|c|c|c|c|c|c|c|}
\hline Tephra & $\mathbf{R b}$ & $\mathrm{Sr}$ & $Y$ & $\mathrm{Zr}$ & $\mathrm{Nb}$ & $\mathrm{Ba}$ & La & $\mathrm{Ce}$ & $\mathrm{Pr}$ & $\mathrm{Nd}$ & Sm & $\mathrm{Eu}$ & Gd & Tb & Dy & Ho & $\mathrm{Er}$ & $\mathrm{Tm}$ & $\mathrm{Yb}$ & Lu & $\mathrm{Hf}$ & $\mathrm{Ta}$ & $\mathrm{Pb}$ & Th & $U$ \\
\hline H1104-71 & 61.1 & 176 & 111 & 523 & 84.3 & 640 & 92.7 & 146 & 19.2 & 84.7 & 21.6 & 3.23 & 19.8 & 3.22 & 20.3 & 4.18 & 11.7 & 1.76 & 10.5 & 1.65 & 17.1 & 6.01 & 16.0 & 13.2 & 3.01 \\
\hline S.D. $(n=8)$ & 9.53 & 26.3 & 19.9 & 90.9 & 14.1 & 91.0 & 15.9 & 26.2 & 2.71 & 17.2 & 9.92 & 0.61 & 3.04 & 0.74 & 4.89 & 1.51 & 3.18 & 0.75 & 2.19 & 0.39 & 2.88 & 1.16 & 4.54 & 2.72 & 0.48 \\
\hline H1104-72 & 69.8 & 184 & 105 & 554 & 87.5 & 639 & 89.2 & 143 & 20.1 & 80.5 & 18.7 & 3.16 & 19.8 & 3.08 & 20.3 & 4.28 & 10.6 & 1.73 & 9.17 & 1.46 & 15.9 & 5.38 & 12.1 & 12.6 & 3.09 \\
\hline S.D. $(n=9)$ & 23.7 & 16.4 & 10.6 & 39.3 & 7.71 & 50.5 & 6.80 & 10.6 & 2.47 & 8.47 & 2.75 & 0.63 & 3.10 & 0.50 & 3.88 & 0.73 & 1.43 & 0.48 & 1.25 & 0.22 & 2.33 & 0.59 & 1.56 & 1.82 & 0.32 \\
\hline H1104-73 & 61.6 & 179 & 107 & 542 & 83.4 & 636 & 95.0 & 149 & 19.5 & 86.4 & 20.6 & 1.68 & 19.9 & 3.03 & 20.8 & 3.72 & 11.5 & 1.56 & 8.98 & 1.84 & 16.7 & 5.42 & 14.6 & 11.9 & 3.37 \\
\hline S.D. $(n=11)$ & 7.17 & 16.4 & 15.0 & 47.2 & 4.43 & 30.4 & 15.2 & 17.3 & 1.81 & 7.93 & 4.29 & 1.55 & 5.38 & 0.59 & 4.44 & 0.87 & 3.31 & 0.56 & 2.05 & 0.74 & 3.30 & 1.03 & 2.91 & 1.52 & 0.78 \\
\hline H3-76 & 63.3 & 202 & 110 & 520 & 80.1 & 680 & 93.4 & 155 & 20.5 & 83.4 & 18.9 & 2.90 & 18.7 & 3.10 & 18.5 & 3.82 & 11.9 & 1.57 & 10.7 & 1.71 & 16.1 & 5.63 & 14.2 & 13.2 & 2.95 \\
\hline S.D. $(n=7)$ & 5.38 & 54.9 & 10.6 & 48.4 & 5.78 & 42.6 & 9.88 & 15.8 & 1.60 & 7.96 & 1.99 & 0.50 & 3.07 & 0.55 & 2.13 & 0.70 & 1.82 & 0.13 & 2.20 & 0.34 & 2.58 & 0.64 & 2.64 & 1.48 & 0.43 \\
\hline H3-73 & 71.2 & 185 & 109 & 504 & 83.5 & 664 & 92.2 & 153 & 20.0 & 80.1 & 30.3 & 2.64 & 19.3 & 2.69 & 18.8 & 3.63 & 11.1 & 1.72 & 10.3 & 1.56 & 15.1 & 5.61 & 28.0 & 12.8 & 3.28 \\
\hline S.D. $(n=8)$ & 18.3 & 12.0 & 8.96 & 31.9 & 3.34 & 22.1 & 5.69 & 9.01 & 1.21 & 6.11 & 31.0 & 0.91 & 3.27 & 0.44 & 3.56 & 0.74 & 1.81 & 0.52 & 1.76 & 0.23 & 2.63 & 0.28 & 21.5 & 1.27 & 0.90 \\
\hline H3-66 & 62.4 & 191 & 103 & 494 & 83.3 & 695 & 91.7 & 156 & 20.6 & 82.0 & 18.1 & 2.97 & 19.6 & 2.48 & 18.6 & 3.73 & 11.6 & 1.38 & 10.5 & 1.68 & 13.9 & 5.15 & 16.9 & 12.6 & 3.10 \\
\hline S.D. $(n=7)$ & 4.87 & $13 / 7$ & 9.67 & 44.3 & 3.1 & 34.0 & 6.99 & 7.17 & 1.86 & 7.88 & 2.47 & 0.33 & 3.14 & 0.37 & 2.68 & 0.60 & 1.97 & 0.28 & 1.66 & 0.30 & 2.08 & 0.44 & 4.99 & 0.87 & 0.23 \\
\hline HS-77 & 48.2 & 279 & 97.2 & 906 & 76.8 & 534 & 77.1 & 123 & 17.3 & 77.7 & 17.7 & 3.69 & 20.4 & 2.77 & 18.5 & 3.89 & 11.9 & 1.81 & 9.27 & 1.49 & 22.9 & 5.04 & 10.5 & 10.4 & 2.46 \\
\hline S.D. $(n=9)$ & 3.67 & 18.9 & 12.7 & 96.0 & 3.40 & 34.3 & 7.24 & 5.77 & 2.06 & 10.7 & 2.08 & 0.86 & 2.47 & 0.67 & 3.20 & 0.62 & 2.19 & 0.50 & 1.32 & 0.40 & 2.31 & 0.72 & 1.77 & 1.10 & 0.25 \\
\hline HS-78 & 43.7 & 242 & 83.2 & 686 & 68.3 & 388 & 64.1 & 110 & 14.5 & 67.1 & 14.3 & 3.51 & 14.0 & 2.27 & 15.9 & 2.88 & 9.36 & 1.23 & 7.70 & 1.20 & 16.6 & 4.16 & 9.03 & 7.44 & 2.53 \\
\hline S.D. $(n=10)$ & 4.96 & 27.4 & 9.40 & 60.5 & 3.13 & 37.0 & 6.23 & 7.12 & 1.26 & 7.87 & 2.07 & 0.57 & 2.45 & 0.17 & 1.83 & 0.28 & 1.83 & 0.22 & 1.37 & 0.29 & 1.78 & 0.38 & 1.60 & 0.83 & 1.43 \\
\hline HS-79 & 45.8 & 213 & 77.1 & 579 & 67.3 & 382 & 63.0 & 113 & 14.8 & 65.4 & 15.4 & 2.80 & 15.1 & 2.12 & 13.3 & 2.69 & 8.93 & 1.42 & 7.27 & 1.21 & 13.6 & 4.08 & 11.0 & 7.14 & 2.22 \\
\hline S.D. $(n=7)$ & 5.75 & 55.6 & 12.0 & 162 & 4.77 & 55.6 & 8.65 & 12.7 & 1.55 & 9.10 & 2.93 & 1.33 & 2.51 & 0.47 & 2.02 & 0.56 & 1.24 & 0.43 & 1.36 & 0.26 & 2.87 & 0.59 & 3.14 & 1.59 & 0.21 \\
\hline H4-101 & 65.1 & 129 & 132 & 358 & 110 & 737 & 82.5 & 136 & 19.4 & 85.5 & 22.0 & 2.86 & 21.1 & 3.41 & 23.9 & 4.60 & 13.5 & 2.09 & 12.7 & 1.95 & 12.7 & 8.29 & 15.5 & 14.8 & 3.34 \\
\hline S.D. $(n=9)$ & 4.27 & 15.9 & 22.4 & 61.4 & 17.6 & 72.4 & 10.4 & 11.5 & 2.07 & 13.0 & 5.98 & 0.77 & 5.50 & 0.72 & 5.01 & 0.87 & 2.29 & 0.49 & 2.09 & 0.43 & 2.44 & 1.83 & 2.43 & 1.60 & 0.48 \\
\hline H4-87 & 74.0 & 124 & 127 & 320 & 105 & 785 & 79.8 & 155 & 19.5 & 83.8 & 20.7 & 3.23 & 21.1 & 2.98 & 24.5 & 4.89 & 13.0 & 1.81 & 11.7 & 1.75 & 12.6 & 7.04 & 27.0 & 13.9 & 3.27 \\
\hline S.D. $(\mathrm{n}=8)$ & 5.56 & 11.2 & 7.62 & 24.2 & 12.7 & 21.9 & 4.50 & 14.5 & 1.60 & 8.97 & 2.22 & 0.69 & 2.70 & 0.44 & 1.16 & 0.89 & 1.49 & 0.55 & 1.78 & 0.38 & 2.33 & 1.63 & 10.2 & 1.06 & 0.31 \\
\hline H4-84 & 75.9 & 122 & 117 & 298 & 101 & 724 & 73.9 & 130 & 17.6 & 73.7 & 19.0 & 3.14 & 19.9 & 3.03 & 19.3 & 4.22 & 12.3 & 1.95 & 9.93 & 1.47 & 11.1 & 6.00 & 27.0 & 12.2 & 3.44 \\
\hline S.D. $(\mathrm{n}=9)$ & 6.45 & 23.2 & 15.8 & 38.4 & 12.9 & 57.5 & 8.12 & 14.1 & 1.56 & 8.72 & 3.20 & 0.79 & 2.36 & 0.79 & 3.74 & 0.63 & 1.82 & 0.44 & 1.88 & 0.42 & 2.59 & 0.91 & 13.3 & 1.57 & 1.04 \\
\hline H5-4 & 62.7 & 114 & 99.3 & 216 & 84.4 & 682 & 55.5 & 107 & 14.5 & 62.6 & 16.1 & 2.34 & 17.4 & 2.99 & 17.8 & 3.84 & 10.6 & 1.54 & 9.28 & 1.36 & 8.48 & 5.75 & 13.1 & 11.6 & 3.26 \\
\hline S.D. $(n=11)$ & 1.92 & 12.5 & 10.4 & 19.6 & 2.90 & 44.9 & 4.67 & 6.72 & 1.19 & 5.59 & 2.02 & 0.37 & 1.58 & 0.52 & 2.19 & 0.34 & 1.44 & 0.18 & 1.14 & 0.18 & 0.92 & 0.51 & 5.68 & 1.31 & 0.36 \\
\hline H5-5 & 62.9 & 144 & 101 & 233 & 85.8 & 745 & 59.1 & 115 & 15.3 & 65.4 & 16.7 & 2.56 & 17.0 & 3.34 & 18.7 & 3.98 & 11.6 & 1.73 & 9.88 & 1.53 & 9.99 & 6.27 & 12.5 & 13.2 & 3.42 \\
\hline S.D. $(\mathrm{n}=7)$ & 3.79 & 23.1 & 7.12 & 22.5 & 5.49 & 16.9 & 4.08 & 8.55 & 1.08 & 5.31 & 2.80 & 0.32 & 0.56 & 0.32 & 1.83 & 0.40 & 1.45 & 0.20 & 0.82 & 0.14 & 0.78 & 0.47 & 1.91 & 1.25 & 0.51 \\
\hline HA-19 & 38.3 & 260 & 50.1 & 420 & 42.5 & 364 & 44.5 & 83.0 & 10.7 & 45.7 & 9.53 & 2.79 & 9.27 & 1.78 & 9.16 & 2.19 & 4.71 & 0.84 & 5.67 & 0.75 & 9.38 & 2.63 & 9.15 & 6.07 & 1.71 \\
\hline S.C. $(\mathrm{n}=8)$ & 2.73 & 28.6 & 8.80 & 67.4 & 3.88 & 46.0 & 6.42 & 10.4 & 1.29 & 8.78 & 1.90 & 0.56 & 2.19 & 0.54 & 1.46 & 0.32 & 1.03 & 0.32 & 1.53 & 0.30 & 1.91 & 0.53 & 2.49 & 1.11 & 0.36 \\
\hline
\end{tabular}


Table 3: (continued)

\begin{tabular}{|c|c|c|c|c|c|c|c|c|c|c|c|c|c|c|c|c|c|c|c|c|c|c|c|c|c|}
\hline Tephra & $\mathbf{R b}$ & $\mathrm{Sr}$ & $\mathbf{Y}$ & $\mathrm{Zr}$ & $\mathrm{Nb}$ & $\mathrm{Ba}$ & La & $\mathrm{Ce}$ & $\mathrm{Pr}$ & $\mathbf{N d}$ & Sm & Eu & Gd & Tb & Dy & Ho & Er & $\mathrm{Tm}$ & $\mathrm{Yb}$ & Lu & Hf & Ta & $\mathrm{Pb}$ & Th & U \\
\hline HB-18 & 40.7 & 272 & 49.1 & 421 & 42.6 & 340 & 44.3 & 79.8 & 12.2 & 41.1 & 10.1 & 2.41 & 9.67 & 1.33 & 8.15 & 2.02 & 5.95 & 1.02 & 5.61 & 0.69 & 9.78 & 2.39 & 7.80 & 5.13 & 1.55 \\
\hline S.D. $(n=7)$ & 8.00 & 54.5 & 10.4 & 109 & 6.47 & 43.5 & 8.52 & 12.0 & 5.76 & 9.16 & 2.12 & 9.57 & 1.82 & 0.43 & 2.67 & 0.54 & 2.38 & 0.50 & 1.96 & 0.12 & 3.07 & 0.52 & 2.81 & 1.68 & 0.23 \\
\hline HC-14 & 40.9 & 318 & 59.2 & 457 & 47.4 & 403 & 48.7 & 93.0 & 11.9 & 51.8 & 11.6 & 3.60 & 11.9 & 1.76 & 11.5 & 2.51 & 6.45 & 0.98 & 5.53 & 0.87 & 10.9 & 2.86 & 9.35 & 6.06 & 1.89 \\
\hline S.D. $(\mathrm{n}=9)$ & 3.26 & 36.9 & 7.15 & 51.6 & 2.63 & 41.50 & 4.69 & 8.69 & 1.12 & 7.07 & 2.52 & 0.36 & 2.34 & 0.62 & 1.52 & 0.42 & 1.08 & 0.27 & 1.29 & 0.21 & 1,98 & 0.50 & 1.65 & 0.82 & 0.25 \\
\hline HM-24 & 38.3 & 314 & 73.5 & 523 & 54.1 & 399 & 52.7 & 101 & 13.4 & $\begin{array}{ll}62.8 \\
\end{array}$ & 17.3 & 4.03 & 15.2 & 2.22 & 13.0 & 2.69 & 7.74 & 0.90 & 6.94 & 1.09 & 12.7 & 3.31 & 10.9 & 6.06 & 2.00 \\
\hline S.D. $(n=8)$ & 4.16 & 36.0 & 17.2 & 105 & 15.5 & 77.4 & 10.5 & 23.8 & 2.66 & 17.6 & 6.00 & 1.15 & 3.71 & 0.59 & 2.99 & 0.50 & 2.80 & 0.58 & 1.45 & 0.26 & 1.99 & 1.05 & 5.50 & 1.21 & 0.46 \\
\hline HN-20 & 39.6 & 304 & 63.9 & 522 & 48.4 & 403 & 53.3 & 95.8 & 12.3 & 55.7 & 13.7 & 3.41 & 12.5 & 1.88 & 11.5 & 2.72 & 6.79 & 0.91 & 6.49 & 1.02 & 13.3 & 3.37 & 8.58 & 6.59 & 1.93 \\
\hline S.D. $(n=8)$ & 3.37 & 24.4 & 8.99 & 55.2 & 2.09 & 17.8 & 3.32 & 3.35 & 1.42 & 3.26 & 1.11 & 0.42 & 2.22 & 0.40 & 1.42 & 0.42 & 1.67 & 0.31 & 1.36 & 0.21 & 1.63 & 0.45 & 1.57 & 1.01 & 0.17 \\
\hline HX-1 & 65.3 & 227 & 75.1 & 533 & 76.7 & 523 & 70.4 & 132 & 16.5 & 67.9 & 13.9 & 3.04 & 14.7 & 2.08 & 13.2 & 2.86 & 7.85 & 1.3 & 7.26 & 1.12 & 15.1 & 5.15 & 12.0 & 10.2 & 2.40 \\
\hline S.D. $(n=10)$ & 27.0 & 98.8 & 10.4 & 170 & 20.1 & 113 & 13.1 & 21.1 & 2.40 & 6.10 & 1.23 & 1.40 & 1.89 & 0.63 & 2.85 & 0.39 & 1.18 & 0.58 & 0.91 & 0.35 & 3.77 & 1.42 & 2.68 & 3.39 & 1.65 \\
\hline HX-2 & 63.1 & 163 & 90.8 & 455 & 76.5 & 568 & 78.4 & 139 & 17.6 & 75.5 & 15.7 & 2.84 & 16.3 & 2.30 & 14.9 & 2.94 & 8.87 & 1.26 & 8.84 & 1.35 & 12.7 & 4.94 & 11.5 & 10.6 & 3.05 \\
\hline S.D. $(n=8)$ & 3.36 & 33.8 & 11.1 & 127 & 4.74 & 27.1 & 17.5 & 25.8 & 2.88 & 16.00 & 2.89 & 0.48 & 2.32 & 0.28 & 1.86 & 0.48 & 2.53 & 0.26 & 1.76 & 0.29 & 3.65 & 0.63 & 2.72 & 1.23 & 0.32 \\
\hline HX-3 & 42.0 & 321 & 60.3 & 451 & 49.5 & 398 & 49.9 & 94.7 & 12.4 & 49.6 & 12.7 & 3.27 & 13.0 & 2.04 & 11.1 & 2.61 & 5.71 & 0.73 & 5.36 & 1.03 & 11.0 & 3.24 & 18.7 & 6.18 & 1.82 \\
\hline S.D. $(n=4)$ & 5.89 & 14.2 & 12.0 & 135 & 6.03 & 84.1 & 8.23 & 13.8 & 3.09 & 9.03 & 1.90 & 0.76 & 3.53 & 0.71 & 1.83 & 0.48 & 1.79 & 0.36 & 1.13 & 0.41 & 3.67 & 0.64 & 8.23 & 1.32 & 0.27 \\
\hline HY-7 & 40.4 & 318 & 66.9 & 519 & 42.6 & 410 & 53.4 & 95.3 & 13.0 & 55.2 & 13.2 & 2.65 & 11.1 & 2.08 & 12.1 & 2.61 & 7.02 & 1.10 & 6.09 & 1.03 & 13.3 & 3.22 & 19.4 & 7.78 & 1.94 \\
\hline S.D. $(n=10)$ & 3.75 & 24.3 & 8.65 & 49.0 & 3.95 & 27.0 & 5.29 & 16.4 & 2.23 & 6.24 & 3.42 & 0.90 & 1.69 & 0.85 & 2.00 & 0.60 & 1.14 & 0.36 & 1.52 & 0.44 & 1.58 & 0.63 & 24.7 & 1.17 & 0.27 \\
\hline HZ-10 & 57.2 & 248 & 88.9 & 458 & 70.6 & 561 & 73.8 & 129 & 16.9 & 71.7 & 15.4 & 3.48 & 15.3 & 2.50 & 14.3 & 3.16 & 9.41 & 1.31 & 8.63 & 1.22 & 14.0 & 5.33 & 13.4 & 10.2 & 3.01 \\
\hline S.D. $(n=10)$ & 11.0 & 74.3 & 18.2 & 70.1 & 11.9 & 107 & 14.0 & 24.8 & 3.38 & 12.9 & 3.16 & 0.82 & 2.84 & 0.79 & 3.17 & 0.92 & 1.84 & 0.52 & 1.93 & 0.39 & 2.59 & 1.07 & 9.16 & 2.06 & 0.61 \\
\hline HZ-9 & 52.1 & 240 & 80.3 & 477 & 60.7 & 512 & 66.8 & 121 & 15.9 & 69.8 & 14.2 & 3.04 & 15.5 & 2.43 & 14.1 & 3.11 & 9.41 & 1.26 & 7.79 & 1.57 & 13.4 & 4.93 & 12.9 & 9.75 & 2.55 \\
\hline S.D. $(\mathrm{n}=9)$ & 13.3 & 61.8 & 25.4 & 180 & 18.7 & 126 & 18.0 & 32.1 & 4.46 & 18.2 & 5.92 & 0.45 & 3.35 & 0.80 & 3.62 & 1.27 & 2.53 & 0.75 & 2.10 & 0.32 & 4.71 & 2.16 & 2.24 & 2.67 & 0.53 \\
\hline Landnám-15 & 121 & 60.4 & 80.8 & 801 & 137 & 496 & 118 & 207 & 24.2 & 87.6 & 16.8 & 1.79 & 15.3 & 2.71 & 14.5 & 3.10 & 8.94 & 1.18 & 8.36 & 1.18 & 24.0 & 9.71 & 15.4 & 22.9 & 6.45 \\
\hline S.D. $(n=9)$ & 5.32 & 2.76 & 5.76 & 50.1 & 4.97 & 22.2 & 9.90 & 13.0 & 3.36 & 9.87 & 1.61 & 0.29 & 1.73 & 0.24 & 1.57 & 0.33 & 1.34 & 0.18 & 0.56 & 0.08 & 5.43 & 0.75 & 3.52 & 1.93 & 0.75 \\
\hline Landnám-14 & 122 & 62.8 & 99.8 & 964 & 150 & 524 & 127 & 220 & 24.2 & 92.4 & 18.6 & 2.33 & 17.7 & 2.85 & 16.9 & 4.49 & 9.80 & 1.49 & 9.69 & 1.46 & 25.9 & 10.5 & 17.1 & 25.1 & 5.95 \\
\hline S.D. $(n=9)$ & 4.98 & 4.12 & 15.7 & 156 & 18.5 & 36.2 & 13.5 & 41.9 & 2.14 & 10.9 & 2.51 & 1.15 & 3.34 & 0.34 & 2.44 & 2.97 & 1.14 & 0.44 & 1.65 & 0.30 & 4.62 & 1.64 & 4.30 & 3.09 & 0.59 \\
\hline Landnám-11 & 7.25 & 338 & 22.0 & 128 & 17.2 & 95.3 & 13.3 & 27.8 & 4.14 & 19.4 & 5.29 & 1.17 & 5.07 & 0.76 & 4.27 & 0.93 & 2.38 & 024 & 2.25 & 0.31 & 3.87 & 1.11 & 1.56 & 1.13 & 0.37 \\
\hline S.D. $(n=7)$ & 0.90 & 10.2 & 1.83 & 9.15 & 0.81 & 4.18 & 1.09 & 1.01 & 0.34 & 1.29 & 0.66 & 0.21 & 0.45 & 0.10 & 0.25 & 0.14 & 0.24 & 0.14 & 0.32 & 0.10 & 0.58 & 0.11 & 0.22 & 0.21 & 0.05 \\
\hline Landnám-11 & 121 & 58.5 & 80.1 & 775 & 136 & 492 & 110 & 198 & 21.7 & 80.8 & 15.5 & 1.74 & 14.5 & 2.44 & 14.3 & 3.00 & 8.73 & 1.23 & 8.31 & 1.22 & 22.4 & 9.11 & 19.8 & 21.8 & 6.18 \\
\hline S.D. $(n=10)$ & 8.28 & 4.99 & 14.1 & 101 & 6.89 & 33.2 & 12.0 & 11.6 & 1.86 & 9.12 & 1.91 & 0.41 & 3.61 & 0.35 & 2.40 & 0.48 & 1.92 & 0.24 & 1.17 & 0.23 & 3.62 & 0.73 & 7.98 & 2.32 & 0.45 \\
\hline Landnám-10 & 119 & 57.7 & 83.0 & 811 & 135 & 472 & 115 & 195 & 22.5 & 82.5 & 16.2 & 1.60 & 14.7 & 2.44 & 13.8 & 2.82 & 8.13 & 1.17 & 8.12 & 1.20 & 22.7 & 9.28 & 14.0 & 22.5 & 5.61 \\
\hline S.D. $(n=10)$ & 4.14 & 4.07 & 6.82 & 57.5 & 6.79 & 29.5 & 9.78 & 16.4 & 2.21 & 9.48 & 2.38 & 0.22 & 1.14 & 0.23 & 1.87 & 0.26 & 0.80 & 0.20 & 0.79 & 0.11 & 1.72 & 0.51 & 2.65 & 1.28 & 0.36 \\
\hline
\end{tabular}


Table 3: (continued)

\begin{tabular}{|c|c|c|c|c|c|c|c|c|c|c|c|c|c|c|c|c|c|c|c|c|c|c|c|c|c|}
\hline Tephra & $\mathbf{R b}$ & $\mathrm{Sr}$ & $\mathbf{Y}$ & $\mathrm{Zr}$ & Nb & $\mathrm{Ba}$ & La & $\mathrm{Ce}$ & $\operatorname{Pr}$ & Nd & Sm & Eu & Gd & Tb & Dy & Ho & Er & Tm & Yb & Lu & $\mathrm{Hf}$ & $\mathrm{Ta}$ & $\mathbf{P b}$ & Th & $\mathbf{U}$ \\
\hline Landnám-8 & 123 & 61.7 & 85.9 & 842 & 137 & 503 & 119 & 203 & 23.3 & 86.5 & 17.1 & 2.00 & 15.5 & 2.56 & 15.5 & 2.95 & 10.4 & 1.26 & 9.20 & 1.23 & 24.5 & 9.68 & 19.5 & 24.4 & 6.47 \\
\hline S.D. $(\mathrm{n}=10)$ & 10.7 & 5.71 & 8.49 & 83.4 & 10.8 & 36.4 & 10.5 & 15.9 & 2.13 & 7.85 & 1.41 & 0.41 & 1.67 & 0.41 & 2.04 & 0.33 & 3.11 & 0.15 & 1.04 & 0.12 & 2.53 & 0.92 & 2.98 & 3.69 & 1.90 \\
\hline Grákolla-16 & 112 & 58.8 & 70.4 & 647 & 120 & 451 & 94.8 & 166 & 18.9 & 68.3 & 13.4 & 1.10 & 13.2 & 1.96 & 13.0 & 2.51 & 7.16 & 1.11 & 6.45 & 1.01 & 16.1 & 7.29 & 13.8 & 16.8 & 4.72 \\
\hline S.D. $(n=8)$ & 6.24 & 9.51 & 7.57 & 68.6 & 6.76 & 43.8 & 11.0 & 18.3 & 2.03 & 9.62 & 1.68 & 0.43 & 2.60 & 0.38 & 1.05 & 0.31 & 0.97 & 0.19 & 1.39 & 0.22 & 2.92 & 1.35 & 2.49 & 3.32 & 0.65 \\
\hline Grákolla-16 & 4.11 & 159 & 33.9 & 110 & 8.38 & 41.6 & 7.98 & 17.2 & 2.71 & 14.3 & 3.90 & 1.08 & 5.16 & 0.88 & 6.04 & 1.18 & 3.61 & 0.51 & 3.70 & 0.56 & 3.20 & 0.52 & 1.21 & 0.78 & 0.24 \\
\hline S.D. $(n=6)$ & 0.82 & 7.37 & 2.06 & 8.05 & 0.57 & 1.73 & 0.82 & 0.79 & 0.27 & 1.70 & 0.32 & 0.11 & 0.37 & 0.23 & 1.06 & 0.17 & 0.48 & 0.10 & 0.61 & 0.12 & 0.30 & 0.16 & 0.31 & 0.10 & 0.07 \\
\hline Grákolla-97 & 109 & 57.3 & 65.6 & 601 & 113 & 405 & 89.5 & 157 & 18.1 & 66.2 & 12.7 & 1.41 & 11.9 & 1.81 & 11.0 & 2.21 & 6.87 & 1.00 & 6.59 & 0.93 & 16.6 & 7.3 & 14.3 & 16.6 & 4.62 \\
\hline S.D. $(n=8)$ & 8.21 & 11.4 & 9.73 & 75.2 & 5.49 & 54.4 & 9.75 & 18.8 & 1.89 & 9.09 & 1.79 & 0.25 & 1.70 & 0.30 & 1.74 & 0.37 & 1.44 & 0.20 & 1.28 & 0.20 & 2.35 & 0.66 & 2.55 & 2.28 & 0.45 \\
\hline Grákolla-97 & 4.80 & 160 & 32.9 & 102 & 8.68 & 41.3 & 7.60 & 16.9 & 2.60 & 15.4 & 4.46 & 1.25 & 5.77 & 0.90 & 6.21 & 1.32 & 3.73 & 0.58 & 3.18 & 0.53 & 3.26 & 0.56 & 1.50 & 0.82 & 0.19 \\
\hline S.D. $(n=5)$ & 0.76 & 9.60 & 2.33 & 6.85 & 0.77 & 2.80 & 0.23 & 1.04 & 0.23 & 2.14 & 0.44 & 0.13 & 0.81 & 0.17 & 0.63 & 0.20 & 0.65 & 0.15 & 0.38 & 0.09 & 0.91 & 0.08 & 0.24 & 0.16 & 0.04 \\
\hline $\begin{array}{c}\text { Grákolla- } \\
101\end{array}$ & 123 & 54.3 & 66.6 & 601 & 118 & 430 & 91.1 & 163 & 18.2 & 70.6 & 12.3 & 1.33 & 12.0 & 1.94 & 12.2 & 2.43 & 6.86 & 1.03 & 6.81 & 0.90 & 16.3 & 7.48 & 14.5 & 16.8 & 4.98 \\
\hline S.D. $(n=9)$ & 24.2 & 4.91 & 9.89 & 71.3 & 10.3 & 25.8 & 10.1 & 18.9 & 2.06 & 12.1 & 2.96 & 0.49 & 1.85 & 0.39 & 3.21 & 0.43 & 1.23 & 0.22 & 1.53 & 0.14 & 2.39 & 0.59 & 2.03 & 2.76 & 0.78 \\
\hline A1875-D4 & 53.3 & 104 & 54.9 & 367 & 31.6 & 330 & 36.6 & 72.1 & 9.11 & 38.6 & 9.29 & 1.84 & 9.25 & 1.58 & 10.1 & 1.97 & 6.38 & 0.86 & 5.94 & 0.88 & 9.61 & 2.22 & 5.61 & 7.36 & 1.99 \\
\hline S.D. $(n=9)$ & 4.54 & 9.07 & 4.72 & 55.9 & 3.46 & 25.7 & 2.85 & 4.36 & 0.53 & 3.53 & 1.57 & 0.60 & 1.61 & 0.19 & 1.65 & 0.29 & 0.70 & 0.18 & 1.11 & 0.17 & 1.72 & 0.29 & 0.83 & 0.86 & 0.18 \\
\hline A1875-D3 & 58.6 & 119 & 71.0 & 451 & 35.7 & 380 & 45.2 & 80.9 & 10.5 & 44.1 & 10.7 & 1.91 & 12.0 & 2.06 & 12.0 & 2.56 & 8.59 & 1.23 & 7.98 & 1.19 & 11.6 & 2.70 & 5.78 & 8.65 & 2.21 \\
\hline S.D. $(n=9)$ & 3.20 & 9.50 & 7.51 & 37.5 & 1.90 & 30.4 & 3.88 & 7.54 & 0.93 & 4.75 & 2.20 & 0.37 & 1.00 & 0.33 & 2.25 & 0.50 & 0.98 & 0.24 & 1.39 & 0.14 & 1.57 & 0.27 & 0.81 & 1.28 & 0.34 \\
\hline A1875-D2 & 56.6 & 118 & 71.3 & 458 & 34.7 & 379 & 46.1 & 80.0 & 10.5 & 45.2 & 10.5 & 1.59 & 11.4 & 1.83 & 11.7 & 2.53 & 7.13 & 1.16 & 7.72 & 1.05 & 11.5 & 2.53 & 7.88 & 8.61 & 2.11 \\
\hline S.D. $(n=8)$ & 4.16 & 14.2 & 4.07 & 25.9 & 1.74 & 11.9 & 4.30 & 5.62 & 0.54 & 4.47 & 1.78 & 0.76 & 1.90 & 0.40 & 1.47 & 0.52 & 1.20 & 0.27 & 0.88 & 0.19 & 1.46 & 0.28 & 3.31 & 0.72 & 0.27 \\
\hline A1875-D1 & 58.9 & 117 & 72.4 & 462 & 36.1 & 374 & 45.0 & 80.0 & 10.3 & 45.7 & 10.3 & 1.64 & 11.2 & 2.03 & 11.8 & 2.69 & 7.64 & 1.20 & 7.55 & 1.16 & 11.7 & 2.76 & 6.17 & 8.65 & 2.26 \\
\hline S.D. $(n=10)$ & 3.07 & 15.6 & 6.50 & 30.4 & 1.65 & 20.8 & 3.42 & 4.80 & 0.49 & 5.31 & 1.23 & 0.50 & 1.49 & 0.25 & 1.77 & 0.28 & 1.21 & 0.25 & 0.98 & 0.24 & 1.81 & 0.24 & 0.46 & 0.60 & 0.36 \\
\hline A1875-55 & 63.8 & 116 & 73.9 & 466 & 41.2 & 400 & 48.4 & 85.7 & 11.1 & 47.2 & 12.0 & 1.87 & 12.4 & 1.96 & 11.6 & 2.76 & 8.10 & 1.17 & 7.91 & 1.24 & 13.5 & 3.26 & 7.72 & 9.81 & 2.54 \\
\hline S.D. $(n=9)$ & 4.73 & 14.5 & 7.81 & 34.2 & 4.42 & 37.3 & 3.32 & 6.2 & 0.54 & 2.41 & 3.15 & 0.45 & 1.28 & 0.15 & 1.27 & 0.31 & 1.82 & 0.22 & 1.19 & 0.25 & 1.78 & 0.28 & 2.40 & 0.61 & 0.41 \\
\hline A1875-55 & 7.52 & 169 & 30.2 & 119 & 12.8 & 75.1 & 10.3 & 23.2 & 3.32 & 16.1 & 4.72 & 1.35 & 5.50 & 0.99 & 5.61 & 1.25 & 3.94 & 0.56 & 3.43 & 0.47 & 3.41 & 0.84 & 1.49 & 1.04 & 0.31 \\
\hline S.D. $(n=10)$ & 1.33 & 5.47 & 3.30 & 16.1 & 1.78 & 8.78 & 1.48 & 3.22 & 0.50 & 1.93 & 0.85 & 0.15 & 0.86 & 0.11 & 0.74 & 0.29 & 0.47 & 0.06 & 0.55 & 0.09 & 0.58 & 0.14 & 0.32 & 0.23 & 0.05 \\
\hline A1875-54 & 59.7 & 108 & 72.9 & 465 & 37.6 & 381 & 48.0 & 82.2 & 10.5 & 46.3 & 11.4 & 1.92 & 11.5 & 1.97 & 12.1 & 2.53 & 7.98 & 1.15 & 7.69 & 1.18 & 13.4 & 2.94 & 6.99 & 9.29 & 2.26 \\
\hline S.D. $(n=9)$ & 3.64 & 8.01 & 5.36 & 30.8 & 1.46 & 17.9 & 4.20 & 5.64 & 0.54 & 3.61 & 1.53 & 0.38 & 1.38 & 0.25 & 1.76 & 0.26 & 0.49 & 0.19 & 0.98 & 0.25 & 1.91 & 0.39 & 2.48 & 0.91 & 0.20 \\
\hline A1875-B & 61.6 & 114 & 78.6 & 505 & 38.2 & 416 & 49.4 & 87.4 & 11.2 & 49.0 & 11.3 & 1.98 & 13.1 & 2.22 & 12.7 & 2.97 & 8.82 & 1.26 & 8.73 & 1.39 & 14.3 & 3.02 & 6.39 & 9.99 & 2.39 \\
\hline S.D. $(\mathrm{n}=10)$ & 2.72 & 7.63 & 6.74 & 39.9 & 1.96 & 27.7 & 3.6 & 6.88 & 1.12 & 3.02 & 1.47 & 0.24 & 1.80 & 0.23 & 1.54 & 0.28 & 1.13 & 0.23 & 0.85 & 0.19 & 1.24 & 0.32 & 0.75 & 0.74 & 0.24 \\
\hline SILK UN & 57.4 & 339 & 88.6 & 907 & 113 & 603 & 84.2 & 150 & 21.5 & 90.7 & 19.0 & 4.50 & 19.3 & 3.02 & 16.3 & 3.17 & 9.12 & 1.25 & 8.38 & 1.16 & 22.7 & 6.95 & 8.49 & 11.0 & 3.05 \\
\hline S.D. $(n=12)$ & 1.72 & 14.6 & 7.13 & 75.3 & 6.20 & 27.8 & 4.67 & 47.5 & 0.93 & 6.72 & 1.61 & 0.25 & 2.32 & 0.26 & 1.39 & 0.32 & 0.89 & 0.19 & 0.86 & 0.26 & 2.23 & 0.41 & 1.75 & 0.79 & 0.17 \\
\hline
\end{tabular}


Table 3: (continued)

\begin{tabular}{|c|c|c|c|c|c|c|c|c|c|c|c|c|c|c|c|c|c|c|c|c|c|c|c|c|c|}
\hline Tephra & $\mathbf{R b}$ & $\mathrm{Sr}$ & $\mathbf{Y}$ & $\mathrm{Zr}$ & Nb & $\mathrm{Ba}$ & La & $\mathrm{Ce}$ & Pr & $\mathbf{N d}$ & Sm & Eu & Gd & Tb & Dy & Ho & Er & $\mathrm{Tm}$ & $\mathrm{Yb}$ & Lu & Hf & Ta & $\mathbf{P b}$ & Th & $\mathbf{U}$ \\
\hline SILK LN & 58.6 & 349 & 93.8 & 908 & 107 & 560 & 84.0 & 153 & 20.8 & 93.1 & 19.1 & 4.44 & 20.0 & 2.85 & 17.0 & 3.58 & 9.86 & 1.14 & 8.68 & 1.29 & 22.9 & 6.98 & 8.69 & 10.6 & 2.78 \\
\hline S.D. $(\mathrm{n}=7)$ & 8.05 & 26.3 & 15.5 & 139 & 5.93 & 41.9 & 11.0 & 11.6 & 2.06 & 11.7 & 2.81 & 0.56 & 4.70 & 0.71 & 3.08 & 0.72 & 3.18 & 0.15 & 1.36 & 0.36 & 5.61 & 0.62 & 3.03 & 1.79 & 0.16 \\
\hline Ö1362-20 & 76.0 & 58.7 & 129 & 816 & 88.8 & 674 & 81.0 & 151 & 19.8 & 84.6 & 20.6 & 3.01 & 21.4 & 3.72 & 22.2 & 4.63 & 13.8 & 1.91 & 13.2 & 1.94 & 22.2 & 5.88 & 10.8 & 11.7 & 3.03 \\
\hline S.D. $(n=9)$ & 4.69 & 5.19 & 13.3 & 74.1 & 4.47 & 42.8 & 5.91 & 11.4 & 1.54 & 5.50 & 3.49 & 0.66 & 2.19 & 0.45 & 1.34 & 0.69 & 1.57 & 0.34 & 1.09 & 0.30 & 1.54 & 0.59 & 2.03 & 1.04 & 0.25 \\
\hline ö1362-33 & 81.6 & 71.1 & 151 & 955 & 93.7 & 737 & 89.3 & 157 & 21.4 & 92.2 & 22.3 & 3.13 & 25.6 & 4.21 & 25.7 & 5.72 & 15.8 & 2.10 & 14.8 & 2.05 & 25.7 & 6.42 & 11.2 & 13.4 & 3.41 \\
\hline S.D. $(n=9)$ & 3.34 & 4.73 & 19.7 & 91.6 & 6.67 & 59.6 & 9.21 & 20.1 & 2.46 & 14.0 & 2.67 & 0.50 & 2.36 & 0.58 & 2.75 & 0.75 & 1.52 & 0.27 & 1.97 & 0.36 & 3.30 & 0.73 & 1.27 & 1.84 & 0.53 \\
\hline Ö1362-48 & 79.0 & 72.9 & 150 & 950 & 96.2 & 728 & 93.6 & 160 & 23.0 & 96.1 & 30.1 & 3.42 & 23.7 & 4.31 & 25.3 & 5.17 & 16.1 & 2.36 & 15.5 & 2.14 & 26.9 & 6.67 & 19.3 & 13.9 & 3.17 \\
\hline S.D. $(n=11)$ & 3.43 & 12.7 & 14.0 & 70.3 & 5.21 & 41.3 & 8.69 & 7.47 & 3.88 & 9.41 & 27.5 & 0.42 & 2.84 & 0.56 & 3.03 & 0.45 & 1.62 & 0.37 & 2.06 & 0.33 & 3.00 & 0.31 & 32.3 & 1.71 & 0.30 \\
\hline Ö1362-59 & 72.9 & 72.3 & 150 & 923 & 91.6 & 716 & 89.0 & 153 & 20.7 & 90.3 & 22.2 & 3.09 & 22.2 & 4.17 & 24.2 & 5.27 & 14.9 & 2.08 & 14.0 & 2.02 & 24.5 & 6.06 & 12.2 & 12.5 & 2.79 \\
\hline S.D. $(n=12)$ & 5.13 & 18.4 & 13.2 & 79.4 & 8.21 & 63.6 & 9.56 & 17.4 & 2.00 & 11.2 & 8.11 & 0.98 & 4.27 & 0.53 & 4.49 & 0.69 & 2.28 & 0.32 & 2.78 & 0.50 & 3.88 & 1.09 & 8.59 & 2.02 & 0.48 \\
\hline Ö1362-65 & 77.3 & 59.9 & 134 & 811 & 89.9 & 680 & 83.0 & 150 & 19.9 & 85.7 & 19.8 & 2.47 & 21.4 & 3.91 & 23.3 & 4.63 & 14.3 & 1.92 & 13.2 & 1.73 & 23.4 & 5.84 & 9.74 & 11.5 & 2.87 \\
\hline S.D. $(n=10)$ & 6.11 & 8.06 & 10.8 & 62.0 & 4.16 & 49.0 & 5.19 & 13.1 & 1.72 & 7.12 & 4.24 & 0.95 & 3.10 & 0.52 & 3.63 & 0.64 & 2.50 & 0.52 & 1.14 & 0.31 & 2.29 & 0.58 & 1.25 & 1.65 & 0.44 \\
\hline
\end{tabular}

